\author{
UNIVERSIDADE DE SÃO PAULO \\ FACULDADE DE MEDICINA DE RIBEIRÃO PRETO
}

\title{
Influência de galectina-3 no curso da infecção por Cryptococcus neoformans
}

Caroline Patini de Rezende

Ribeirão Preto 
UNIVERSIDADE DE SÃO PAULO

FACULDADE DE MEDICINA DE RIBEIRÃO PRETO

PROGRAMA DE PÓS- GRADUAÇÃO EM BIOQUÍMICA

\title{
Influência de galectina-3 no curso da infecção por Cryptococcus neoformans
}

\begin{abstract}
Dissertação apresentada ao programa de pósgraduação em Bioquímica da Faculdade de Medicina de Ribeirão Preto, Universidade de São Paulo, para obtenção do título de Mestre em Bioquímica.
\end{abstract}

Aluna: Caroline Patini de Rezende Orientador: Dr. Fausto Bruno dos Reis Almeida

Ribeirão Preto 
Autorizo a reprodução e divulgação total ou parcial deste trabalho, por qualquer meio convencional ou eletrônico, para fins de estudo e pesquisa, desde que citada a fonte.

Ficha Catalográfica

Rezende, Caroline Patini de

Influência de galectina-3 no curso da infecção por Cryptococcus neoformans. Ribeirão Preto, 2019.

$89 \mathrm{p}$.

Dissertação de Mestrado, apresentada à Faculdade de Medicina de Ribeirão Preto/USP. Área de concentração: Bioquímica.

Orientador: Fausto Bruno dos Reis Almeida.

1. Cryptococcus neoformans. 2. Galectina-3. 3. Expressão gênica 
REZENDE, P.C. Influência de galectina-3 no curso da infecção por Cryptococcus neoformans. Dissertação apresentada à Faculdade de Medicina de Ribeirão Preto da Universidade de São Paulo para obtenção do título de Mestre em Bioquímica.

Aprovado em: $/ 2019$

Banca Examinadora

Prof (a). Dr (a). Instituição:

Julgamento: Assinatura:

Prof (a). Dr (a). Instituição:

Julgamento: Assinatura:

Prof (a). Dr (a). Instituição:

Julgamento: Assinatura:

Prof (a). Dr (a). Instituição:

Julgamento: Assinatura: 
À minha família,

Em especial meus pais Irineu e Maria José por todo o apoio durante esta etapa importante da minha vida. 


\section{AGRADECIMENTOS}

Agradeço primeiramente a Deus que permitiu que tudo isso acontecesse, ao longo da minha vida, sempre guiando o meu caminho e me dando forças para seguir em frente e superar todas as dificuldades.

Ao Dr. Fausto Bruno dos Reis Almeida, pela maestria em me orientar com tamanha competência e confiança. Todos os ensinamentos e dedicação, tornaram possível a realização deste trabalho. Obrigada por ter acreditado no meu potencial, pela confiança em mim depositada e por todas as oportunidades que me foram dadas.

Meus sinceros agradecimentos e admiração!

A Prof. ${ }^{a}$ Dra. Maria Cristina Roque Barreira, por abrir as portas do seu laboratório para a realização deste trabalho, pela disponibilidade e colaboração concedida.

Ao Dr. Thiago Aparecido da Silva, pela sua disponibilidade em me ajudar sempre que preciso. Obrigada por toda colaboração, conselhos, paciência e apoio constante nessa jornada. Sem a sua ajuda, nada disso seria possível. Obrigada pela amizade.

A Dr. ${ }^{a}$ Paula Barbin, por toda colaboração e disponibilidade.

Aos meus pais Maria José e Irineu que me deram a vida e me ensinaram a vive-la com dignidade. A vocês, que iluminaram meus caminhos com afeto e dedicação para que eu pudesse trilha-lo sem medo e cheio de esperança. Vocês sempre se doaram por inteiro, renunciando os seus sonhos para que eu pudesse realizar os meus. Vocês não são apenas os meus pais, são meus amigos e companheiros. Obrigada por todas as vezes que amenizaram minha ansiedade, me mantendo firme diante de todos os obstáculos. Palavras não expressam a importância de vocês para mim.

À toda minha família, pelo apoio incondicional, paciência e compreensão. Em especial a minha avó por todo o carinho, proteção e oração. Vocês são a minha base.

À Patrícia Kellen Martins Oliveira Brito, por esses mais de dois anos de convivência pessoal e profissional. Obrigada por dividir comigo todos os momentos, sejam eles bons ou ruins. Obrigada pela amizade!

Agradeço a todos os meus amigos que dividiram comigo todos os momentos de alegria, conquistas e também de decepções e angústias. Em especial meus amigos, Leonardo, Virgínia e Marília por estarem sempre ao meu lado.

Aos meus amigos de laboratório Verônica e André por toda convivência, risadas e amizade. Mesmo com pouco tempo, vocês fizeram os dias no laboratório mais leves e alegres. 


\section{À Erika Vendrusculo, Patrícia Edivânia Vendrusculo e Sandra Maria de Oliveira}

Thomaz, pelo auxílio técnico, preocupação e carinho que sempre tiveram por mim.

Ao Wander Cosme Ribeiro da Silva e Vera Lucia Aparecida Aguillar Epifânio por todo apoio técnico.

À Maria Ivone Campos Fonseca, Rosemeire Ferreira da Costa Gonçalves e Ronaldo Sordi Campanini pela disponibilidade e ajuda em relação aos assuntos de secretaria.

Aos docentes, pós-graduandos e funcionários da pós-graduação em Bioquímica, pelos ensinamentos e convivência durante esses dois anos.

À FAPESP (Fundação de Amparo à Pesquisa do Estado de São Paulo) pelo financiamento de minha pesquisa de mestrado (Processo 2016/25167-3).

Agradeço a todos que participaram de forma direta ou indireta dessa pesquisa, contribuindo para o resultado final da minha dissertação.

Por fim, obrigado a todas as pessoas que contribuíram para meu sucesso e para meu crescimento pessoal. Sou o resultado da confiança e da força de cada um de vocês. 
"Seja você quem for, seja qual for a posição social que você tenha na vida, a mais alta ou a mais baixa, tenha sempre como meta muita força, muita determinação e sempre faça tudo com muito amor e com muita fé em Deus, que um dia você chega lá.

De alguma maneira, você chega lá. “ Aryton Senna 


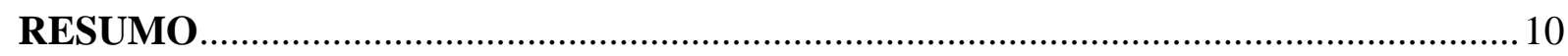

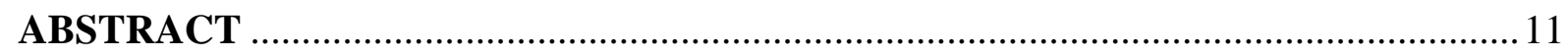

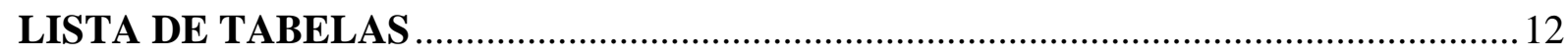

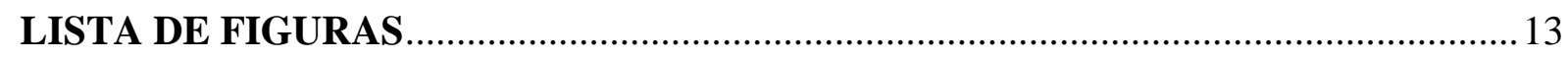

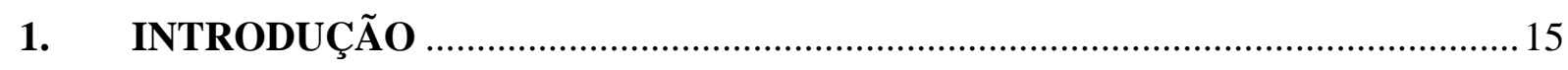

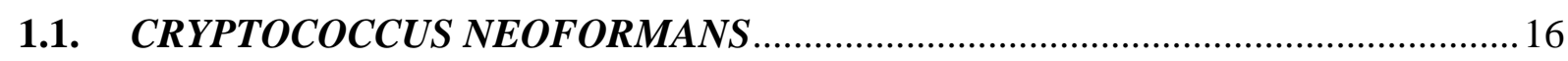

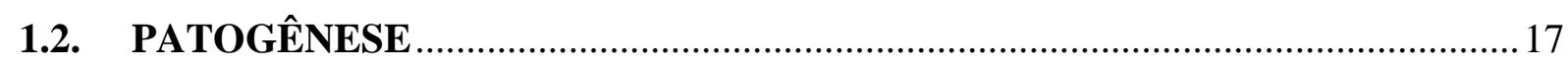

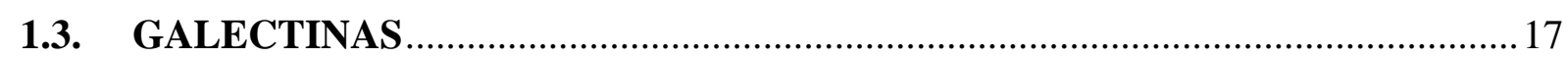

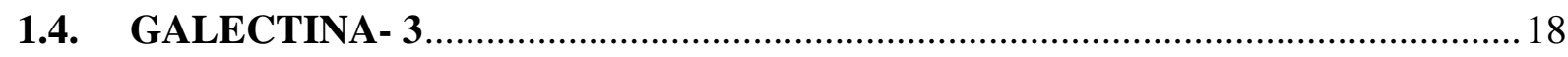

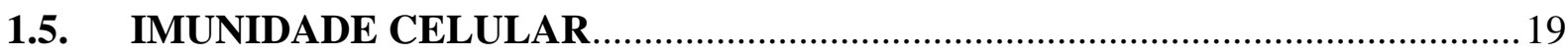

1.5.1. Reconhecimento de patógenos fúngicos através de receptores de reconhecimento padrão (PRRs) do sistema imune inato ........................................... 19

1.5.2. Funções efetoras coordenadas pelas células do sistema imune inato .............22

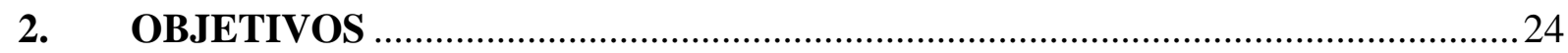

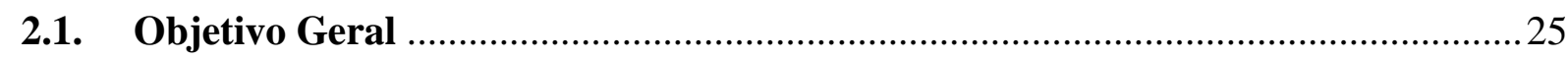

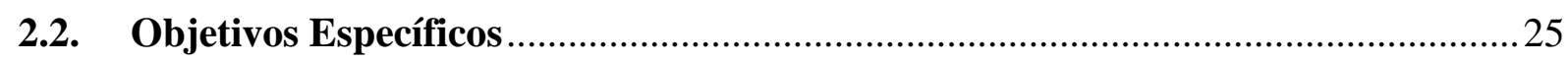

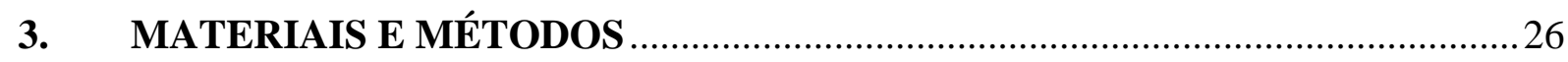

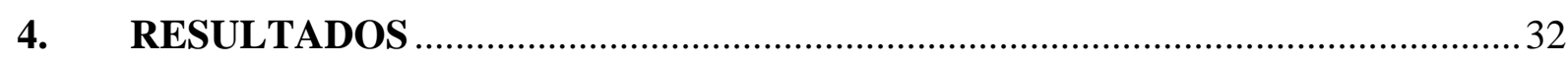

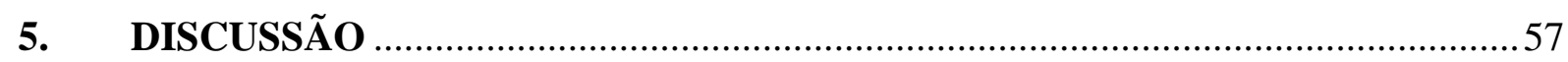

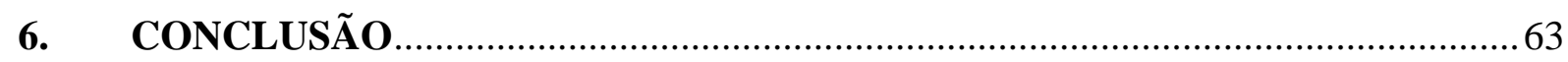

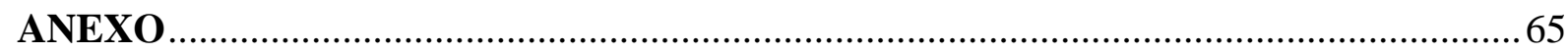

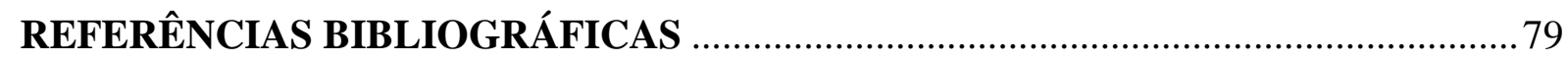


Rezende, P.C. Influência de galectina-3 no curso da infecção por Cryptococcus neoformans. 2019. Dissertação. Faculdade de Medicina de Ribeirão Preto, Universidade de São Paulo, Ribeirão Preto.

\section{RESUMO}

Cryptococcus neoformans, agente causador da criptococose, é considerado o principal patógeno fúngico que acomete indivíduos imunodeprimidos e representa modelo único para estudos de biologia celular, por sua singular característica de ser um patógeno eucarioto com cápsula polissacarídica. Galectina-3 (Gal-3) é uma lectina animal que se liga tipicamente em $\beta$ galactosídeos e exerce o controle fino de várias funções imunológicas, incluindo adesão celular, migração, ativação, apoptose e secreção de citocinas, estando envolvida na resposta imune inata e adaptativa. O presente estudo teve como objetivo avaliar a influência de Gal-3 na infecção por $C$. neoformans. Foi avaliada a sobrevida e quantificada a carga fúngica no pulmão e cérebro de animais selvagens (WT) e knockout para Gal-3 (Gal-3 KO) infectados com C. neoformans. Os animais Gal-3 KO foram mais suscetíveis a criptococose quando comparado aos animais WT. Também foi investigado o perfil de resposta imune no pulmão, baço e cérebro em 3, 7 e 14 dias pós-infecção nos animais WT e Gal-3 KO, e verificado que a deficiência de Gal-3 afeta o perfil de resposta imune Th17 durante a infecção experimental por C. neoformans. A análise do perfil gênico da imunidade inata no pulmão, baço e cérebro permitiu inferir, que durante infecção por $C$. neoformans, Gal-3 está envolvida no aumento da expressão de PRRs responsivos a $\beta$-glucana e manose/quitina (Clec7a e Mrc1), de genes relacionados a inflamação (Cxc11, Cxc19, Cxc110, Ccr1, Ccr5, IL-6) e fagocitose (Sftpd) e diminuição da expressão do receptor CD209a, das citocinas pro-inflamatórias IL-12B e IL-1 $\beta$ e da tirosina- quinase envolvida na transdução de sinal (Syk). Nossos resultados indicam envolvimento de Gal-3 na imunidade antifúngica.

Palavras-chave: Cryptococcus neoformans, galectina-3, expressão gênica 
Rezende, P.C. Influence of galectina-3 on the course of infection by Cryptococcus neoformans. 2019. Dissertação. Faculdade de Medicina de Ribeirão Preto, Universidade de São Paulo, Ribeirão Preto.

\begin{abstract}
Cryptococcus neoformans, the causative agent of cryptococcosis, is considered the main fungal pathogen that affects immunocompromised individuals and represents unique model for cell biology studies, due to its unique characteristic of being a eukaryotic pathogen with polysaccharide capsule. Galectin-3 (Gal-3) is an animal lectin that typically binds to $\beta$ galactosides and exerts fine control of various immune functions, including cell adhesion, migration, activation, apoptosis and cytokine secretion, being involved in the immune response innate and adaptive. The present study aimed to evaluate the influence of Gal-3 on $C$. neoformans infection. We performed survival and quantification of the fungal burden in the lungs and brains of wild type (WT) and knockout for Gal-3 (Gal-3 KO) animals infected with C. neoformans. Gal-3 KO animals were more susceptible to cryptococcosis when compared to WT animals. In addition, when investigating the immune response profile in the brain, lungs, and spleen at 3, 7, and 14 days post-infection from WT and Gal-3 KO, we observed that Gal-3 deficiency affects the Th17 immune response during the experimental infection by $C$. neoformans. The analysis of the gene profile of innate immunity in the lung, spleen and brain, allowed to infer that, during infection by $C$. neoformans, Gal-3 is involved in the increase of PRRs responsive to $\beta$-glucan and mannose / chitin (Clec7a and $\mathrm{Mrc1}$ ), genes related to inflammation (Cxc11, Cxc19, Cxc110, Ccr1, Ccr5, IL-6) and phagocytosis (Sftpd) and decreased expression of CD209a receptor, proinflammatory cytokines IL-12B and IL-1 $\beta$, and tyrosinekinase involved in signal transduction (Syk). Therefore, our results indicate an important role of Gal-3 in antifungal immunity.
\end{abstract}

Keywords: Cryptococcus neoformans, galectin-3, gene expression 


\section{LISTA DE TABELAS}

Tabela 1. Aumento da expressão de genes da resposta imune inata no pulmão de camundongos WT e Gal-3 KO, na ausência e presença da infecção por C. neoformans .40

Tabela 2. Aumento na expressão gênica no baço de camundongos WT e Gal-3 KO, na ausência e presença da infecção por $C$. neoformans

Tabela 3. Superexpressão gênica no cérebro de camundongos WT e Gal-3 KO na ausência e presença da infecção por C. neoformans

Tabela 4. Diminuição da expressão de genes envolvidos na imunidade inata no pulmão de camundongos WT e Gal-3 KO, na ausência e presença da infecção por C. neoformans .46

Tabela 5. Diminuição da expressão de genes envolvidos na imunidade inata no baço de camundongos WT e Gal-3 KO, na ausência e presença da infecção por C. neoformans 49

Tabela 6. Diminuição da expressão de genes envolvidos na imunidade inata no cérebro de camundongos WT e Gal-3 KO, na ausência e presença da infecção por C. neoformans. 53 


\section{LISTA DE FIGURAS}

Figura 1. Análise da sobrevida e carga fúngica de animais Gal-3 $\mathrm{KO}$ infectados com $C$. neoformans..... 33

Figura 2. Avaliação do perfil de resposta imune na criptococose experimental .36

Figura 3. Histopatologia do pulmão, baço e cérebro de animais WT e Gal-3 KO na presença de infecção por $C$. neoformans. .38

Figura 4. Heat map da expressão de genes da imunidade inata antifúngica no pulmão, baço e cérebro de camundongos WT e Gal-3 KO na ausência e presença da infecção por $C$.

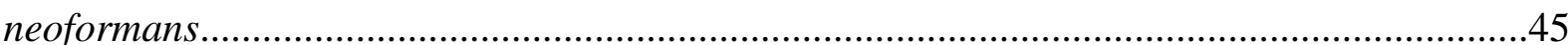

Figura 5. Diagrama de Venn da expressão de genes envolvidos na imunidade inata. .46 
"Mesmo quando tudo pede um pouco mais de calma Até quando o corpo pede um pouco mais de alma A vida não para Enquanto o tempo acelera e pede pressa Eu me recuso, faço hora, vou na valsa A vida é tão rara." 
1. INTRODUÇÃO 


\section{INTRODUÇÃO}

Nos últimos anos, a incidência e prevalência de doenças fúngicas tem aumentado, sendo associada a aproximadamente 1.6 milhões de mortes anualmente (Almeida et al., 2019). A incidência e prevalência das doenças fúngicas no mundo está relacionada com características socioeconômicas, geológicas (Bongomin et al., 2017) e a um sistema imune debilitado ou disfuncional (Shourian e Qureshi, 2019). Os principais fatores de risco para as micoses invasivas incluem infecção pela vírus da imunodeficiência humana (HIV), procedimentos médicos invasivos, terapia imunossupressora prolongada, transplante de órgãos sólidos e neoplasias hematológicas (Shourian e Qureshi, 2019).

Existem cerca de 1.5 milhões de espécies de fungos, mas os principais fungos patogênicos responsáveis por casos de doenças graves são Candida sp., Cryptococcus sp., Aspergillus sp. e Pneumocystis sp. (Stop neglecting fungi, 2017; Shourian e Qureshi, 2019). O gênero Cryptococcus, causador da criptococose, é responsável por aproximadamente 180.000 mortes anuais (Rajasingham et al., 2017).

\subsection{CRYPTOCOCCUS NEOFORMANS}

Cryptococcus neoformans é o principal patógeno que acomete indivíduos imunodeprimidos (Perfect e Casadevall, 2002). Pode ser encontrado em todos os continentes, em diversos nichos ambientais, já tendo sido isolada do solo, árvores e animais, particularmente de excrementos de aves (Lin e Heitman, 2006; Barnett, 2010). A inalação é a principal via de infecção, no entanto, este patógeno tem propensão a disseminar dos pulmões para o sistema nervoso central, particularmente quando a imunidade celular é comprometida. Dados epidemiológicos permitiram concluir que a infecção se associa frequentemente a um estado latente assintomático (Garcia-Hermoso et al., 1999; Goldman et al., 2001; Lindell et al., 2006). Desde os primeiros casos clínicos descritos, associou-se à criptococose a estados de imunossupressão (Baker e Haugen, 1955; Schwartz, 1988). Em indivíduos imunossuprimidos, a infecção ou sua reativação é frequentemente fatal, cursando com quadros de pneumonia e meningoencefalite. Há uma relação direta entre o envolvimento do sistema nervoso central e altas taxas de mortalidade e morbidade (Longo D et al., 2011). Mesmo com intensivo tratamento antifúngico, estima-se que a incidência global de meningite criptococócica foi de 
223.100 casos por ano, resultando em 181.100 mortes anuais em 2014 (Campuzano e Wormley, 2018).

\subsection{PATOGÊNESE}

C. neoformans representa modelo único em estudos de biologia celular devido sua singular característica de ser um patógeno eucarioto com cápsula polissacarídica, estrutura essencial para a sua virulência (Perfect e Casadevall, 2002). Essa cápsula é constituída principalmente de Glucuronoxilomanana (GMX), e dois constituintes em menores proporções, Galactoxylomannan (GalXM), e manoproteínas (Cherniak e Sundstrom, 1994). Dentre os principais fatores de virulência identificados neste patógeno temos a cápsula polissacarídica, sua capacidade de crescer a $37^{\circ} \mathrm{C}$ e a deposição de melanina na parede celular (Kronstad et al., 2012). A cápsula polissacarídica é o principal fator de virulência, proporcionando proteção direta a esse patógeno através da inibição da fagocitose por fagócitos profissionais na ausência de opsoninas e resistência a digestão fagocítica, sendo essencial para a sua sobrevivência no hospedeiro. O material capsular também atua diretamente contra o hospedeiro, através da repressão à migração de fagócitos, interferência na secreção de citocinas, inibição direta da proliferação de células T, indução da apoptose de macrófagos mediado por ligante Fas e atraso na maturação e ativação de células dendríticas (Ma e May, 2009). Além disso, GXM é liberada no meio extracelular durante a infecção e induz efeitos deletérios sobre o hospedeiro (Vecchiarelli, 2000), constituindo-se por tal razão em potencial alvo para o desenvolvimento de vacinas e terapias baseadas em anticorpos específicos, as quais estão sob avaliação (Casadevall et al., 1998; Oscarson et al., 2005)

\subsection{GALECTINAS}

Lectinas representam um grupo único de proteínas estruturalmente diversas, que são ligantes de carboidratos, e dotadas da capacidade de decifrar a informação biológica codificada por estruturas sacarídicas contidas em uma gama de glicoconjugados (Sharon e Lis, 1989). Estão envolvidas na sinalização celular, interação patógeno- hospedeiro e célula-célula no sistema imune, malignidade e direcionamento de proteínas para compartimentos celulares (Gallegos et al., 2014)

Galectinas constituem uma família de lectinas animais altamente conservadas que reconhecem ß-galactose. Os membros dessa família são moléculas multifuncionais, expressas 
no núcleo, citoplasma ou membranas celulares, podendo também ser encontradas extracelularmente, na forma solúvel. Elas reconhecem sequências $N$-acetilactosamina, as quais podem estar contidas em glicanas $N$ - e $O$-ligadas (Barondes et al., 1994). As galectinas contêm domínios conservados de reconhecimento de carboidrato (CDRs) (Kasai e Hirabayashi, 1996; Cooper, 2002). Até o momento, 15 galectinas de mamíferos foram identificadas, sendo subdivididas em três grupos: as que contêm apenas um CRD (galectina-1, -2, -5, -7, -10, -11, 13, -14, -15), que contêm dois distintos CRDs, dispostos em tandem (galectina-4, -6, -8, -9, 12) e galectina-3 (Gal-3) a qual consiste de repetições de tandem incomuns de trechos fusionados no CRD [ revisto em (Liu e Rabinovich, 2005)].

As galectinas podem se ligar bivalentemente ou multivalentemente, podendo interligar glicoconjugados da superfície celular, os quais podem desencadear uma série de eventos de sinalização transmembrana (Brewer et al., 2002; Fred Brewer, 2002; Liu e Rabinovich, 2005). Através desse processo, as galectinas modulam vários processos biológicos como apoptose, ativação, adesão celular e secreção de citocinas (Rabinovich et al., 2002).

\subsection{GALECTINA- 3}

Sem dúvida, Gal-3 é o membro mais estudado da família das galectinas. Esta foi originalmente identificada como uma molécula associada a macrófagos (Mac-2), proteína ubiquamente distribuída, responsável por várias funções biológicas. Embora descoberta pela primeira vez em macrófagos, Gal-3 foi encontrada amplamente distribuída em vários tipos celulares, em tecidos diversos e organismos em distintos estágios de desenvolvimento (Albrandt et al., 1987).

A estrutura de Gal-3 parece ser única entre os membros da família de galectinas, contendo: a) um domínio amino terminal que contém repetições em tandem de uma sequência conservada de nove aminoácidos, Tyr-Pro-Gly- (Pro/Gln) - (Ala/Thr) - (Pro/Ala) - Pro-GlyAla; e b) um domínio carboxi terminal contendo sequências compartilhadas por outros domínios de reconhecimento de carboidrato de lectinas do tipo-S (Albrandt et al., 1987; Robertson et al., 1990).

As funções biológicas de Gal-3 são definidas por sua seletividade intracelular ou localização extracelular. De fato, Gal-3 tem sido proposta para transporte entre o citoplasma e núcleo, com base em sinais de direcionamento que são reconhecidos por importinas, para localização nuclear, e exportin-1 (CRM1), para exportação nuclear. Além do mais, Gal-3 exerce um importante papel na regulação da rota de sinalização de Wnt/ß-catenina, a qual desempenha 
papel chave no desenvolvimento, homeostase tecidual, e crescimento tumoral; ressalta-se, entretanto, que os mecanismos precisos correlacionados a tais efeitos ainda não estão esclarecidos (Shimura et al., 2004).

Gal-3, bem como outras galectinas de vertebrados, carece de sequências sinais de secreção (Dennis et al., 2001), mas sua localização extracelular é indiscutível. Ela pode ser encontrada em associação com a superfície celular ou no interior da matriz ex tracelular (Dabelic et al., 2006; Dumic et al., 2006). Gal- 3 extracelular exerce numerosos efeitos autócrinos e parácrinos, os quais podem mediar a adesão e ativação celular, atuando como quimioatraente para certos tipos de células (Liu e Rabinovich, 2005). Notavelmente, camundongos deficientes em Gal-3 exibem vários fenótipos importantes, embora não esteja claro se eles refletem o prejuízo de funções intracelulares ou extracelulares desta proteína (Yang et al., 2008).

\subsection{IMUNIDADE CELULAR}

\subsubsection{Reconhecimento de patógenos fúngicos através de receptores de reconhecimento padrão (PRRs) do sistema imune inato}

O sistema imune inato é a primeira linha de defesa do organismo na detecção e reconhecimento de uma ampla variedade de perigos, incluindo patógenos fúngicos como $C$. neoformans (Pelka e De Nardo, 2018). O controle ou erradicação dos patógenos inicia-se com o reconhecimento e fagocitose deste através das células fagocíticas. Após o patógeno ser internalizado no fagossomo, ocorre a fusão fago-lisossomo, ativação do inflamassoma e degradação do mesmo. Durante esse processo, as células fagocíticas também produzem espécies reativas de oxigênio (ROS) e nitrogênio (RNS), citocinas, quimiocinas, além de promover a apresentação de antígenos às células $\mathrm{T}$ para que se inicie uma resposta imune adaptativa (Campuzano e Wormley, 2018).

As células imunes do hospedeiro conseguem reconhecer os patógenos fúngicos através dos seus PRRs (Pelka e De Nardo, 2018). Cada PRR reconhece os chamados padrões moleculares associados a patógenos (PAMPs), que nos fungos geralmente incluem os componentes da parede celular como $\beta$-glucanos, mananas e quitina. $\mathrm{O}$ reconhecimento dos PAMPs fúngicos pelos PRRs induz a uma transdução de sinal que coordena os processos imunes inatos, como fagocitose e produção de citocinas (Heung, 2017). Até o presente momento, três classes de diferentes PRRs são bem descritas: receptores do tipo Toll 
transmembrana (TLRs); receptores lectina do tipo C (CLRs); e receptores citosólicos como receptores tipo NOD (NLRs) (Campuzano e Wormley, 2018).

\section{Receptores tipo Toll (TLRs)}

Consistem na família de PRRs melhor caracterizada e exercem papel importante na imunidade, pelo fato de reconhecerem patógenos como bactérias, vírus e fungos, além de promover a modulação de respostas pro e anti- inflamatórias (Tartey e Takeuchi, 2017). São compostos de um domínio extracelular contendo motivos de repetição ricos em leucina e uma cauda citoplasmática que contém o domínio do receptor Toll/ Interleucina-1 (TIR) (Ostrop e Lang, 2017).

Após o reconhecimento de PAMPs pelos TLRs, associados com a molécula MyD88 (exceção para TLR3 que possui ativação independente de MyD88), inicia-se a cascata de transdução de sinais que induz a ativação de proteínas quinases ativadas por mitógenos (MAPKs), fator nuclear Kappa beta $(\mathrm{NFK} \beta)$, genes inflamatórios incluindo fatores reguladores de interferon 5 e 7 (IRF5 e IRF 7) e proteína ativadora 1 (AP-1), promovendo o clearance do patógeno (Gay et al., 2014; Tartey e Takeuchi, 2017).

TLR2 e TLR4 vem ganhando atenção devido sua particularidade em reconhecer ligantes associados a parede celular fúngica (Kawai e Akira, 2011; Vecchiarelli et al., 2013). Por exemplo, TLR2 é capaz de reconhecer $\beta$-glucanos que são expressos na parede celular de vários fungos, entretanto no caso de $C$. neoformans, a função de TLR2 na proteção contra a criptococose depende da cepa e variabilidade da cápsula, pelo fato dessa levedura conseguir mascarar sua camada de $\beta$-glucano com a presença da cápsula polissacarídica (Netea et al., 2006; Sorgi et al., 2009). Além de $\beta$ - glucanos, TLR2 e também TLR4 são capazes de reconhecer GXM, o principal componente da cápsula de C. neoformans (Yauch et al., 2005; Wozniak, 2018). Vários grupos têm mostrado que a fagocitose e internalização da levedura em fagócitos, promovem a ativação de TLRs fagossomais que reconhecem ácidos nucleicos e motivos citosina-fosfato- guanosina não-metilada $(\mathrm{CpG})$ como é o caso de TLR9 que é capaz de reconhecer o DNA genômico do fungo levando ao recrutamento do fagossomo e eliminação do patógeno (Nakamura et al., 2008; Ramirez-Ortiz et al., 2008; Biondo et al., 2011).

Recentemente, estudos avaliando a importância de TLRs e da molécula MyD88 durante infecções fúngicas causadas por C. neoformans, Candida albicans, Aspergillus fumigatus e Paracoccidioides brasiliensis tem demonstrado que camundongos nocautes para MyD88 são mais susceptíveis as infecções fúngicas do que os camundongos selvagens (Biondo et al., 2005; 
Loures et al., 2011; Hung et al., 2016). Com isso, esses resultados podem indicar que, talvez TLRs não sejam protagonistas centrais na imunidade antifúngica, podendo ser necessário a interferência de outros membros PRRs para o reconhecimento e erradicação desses patógenos (Campuzano e Wormley, 2018).

\section{Receptores lectina tipo C (CLRs)}

Receptores lectina tipo C (CLRs) são expressos em células dendríticas (DCs), macrófagos, neutrófilos e outros tipos de células imunes, e também podem ser encontrados de forma solúvel no soro ou outros fluidos corporais (Goyal et al., 2016). Reconhecem porções de carboidratos presentes nos patógenos através dos seus domínios de reconhecimento de carboidratos (CDRs) (Mayer et al., 2017), apresentando papel importante na imunidade antifúngica por reconhecer ligantes de carboidratos presentes nas superfícies de células fúngicas como glucanas, mananas e quitina (Goyal et al., 2018). O reconhecimento do patógeno por CLRs promove a ativação de ITAM (motivo de ativação baseado em tirosina imunorreceptor) como cadeia y do receptor $\mathrm{Fc}(\mathrm{Fc \gamma R})$, recrutamento e ativação da tirosina quinase do baço (Syk) e, por conseguinte, ativação do complexo de sinalização Card9, Bcl10 e Malt1 (Shiokawa et al., 2017) ), que servirá de suporte para ativação de NFKB e MAPK, desencadeando ativação de macrófagos, maturação de células dendríticas e produção de ROS e citocinas para respostas antifúngicas (Ostrop e Lang, 2017).

O papel dos CLRs na resposta imune contra $C$. neoformans ainda é pouco compreendida em comparação com outros fungos (Vautier et al., 2012). Estudos iniciais mostraram que a ingestão da forma acapsular de C. neoformans é inibida tanto por manose solúvel como por $\beta$ 1,3- glucanos, levando a inferir que mesmo na sua forma acapsular, a ingestão deste patógeno por macrófagos murinos ocorre via manose e receptores $\beta$-glucano (Cross e Bancroft, 1995). Ademais, Nakamura et al., e Ishikawa et al., demonstraram que Dectina-1 e Dectina-2, importantes no reconhecimento de $\beta-1,3$ glucano e manose respectivamente, não apresentam papel significativo na infecção por $C$. neoformans devido a capacidade do patógeno em ocultar a camada de $\beta$-1,3 glucano e manose sob sua cápsula polissacarídica (Nakamura et al., 2007; Ishikawa et al., 2013; Nakamura et al., 2015).

Outras espécies de fungos como Aspergillus e Candida também interagem com CLRs durante a infecção, gerando oportunidades para a realização de estudos frente as interações entre esses receptores a nível funcional e genético (Goyal et al., 2018). 


\section{Receptores tipo NOD ou receptores de repetição ricos em leucina (NLRs)}

Consistem em uma família de receptores citoplasmáticos capazes de reconhecer PAMPs fúngicos e após sua ativação podem formar um complexo inflamassoma (Plato et al., 2015; Heung, 2017) promovendo transdução de sinal, ativação da transcrição e autofagia (Kim et al., 2016). Uma vez ativados, esses receptores promovem a ativação de proteínas associadas à apoptose, com ativação do inflamassoma Card - caspase-1 em macrófagos e DCs, produzindo IL-1 e IL-18 (Franchi et al., 2012). Guo et al., e Chen et al., mostram em seus estudos que tanto a internalização do mutante acapsular de C. neoformans (CAP59) como a internalização mediada por opsonização deste fungo, respectivamente, induziam a ativação do inflamassoma NLRP3 com posterior secreção de IL-1, sugerindo que sua cápsula polissacarídica é capaz de mascarar-se após fagocitose (Guo et al., 2014; Chen et al., 2015). No entanto, ainda são necessários maiores estudos para o esclarecimento do papel dos NLRs e da formação de inflamassomas na resposta antifúngica contra C. neoformans (Heung, 2017).

\subsubsection{Funções efetoras coordenadas pelas células do sistema imune inato}

Após o reconhecimento do patógeno fúngico pelas células do sistema imune, a transdução de sinal irá coordenar as funções efetoras dessas células como fagocitose e produção de citocinas. Esses processos podem promover a eliminação do patógeno ou iniciar uma resposta imune adaptativa (Campuzano e Wormley, 2018).

Durante a infecção fúngica causada por $C$. neoformans, a inalação da levedura ou de basidiósporos dessecados é detectado por macrófagos residentes do pulmão que promovem o reconhecimento e engolfamento da levedura e início da resposta imune anti-criptococócica (Lohmann-Matthes, 1994 ; Mcquiston e Williamson, 2012). Dependendo do seu status de ativação, os macrófagos desempenham um importante papel na erradicação ou disseminação da doença. Essas células podem assumir dois fenótipos diferentes: M1 ou macrófagos classicamente ativados; e M2 ou macrófagos alternativamente ativados (Leopold Wager, 2014). Esses fenótipos são definidos por meio da produção de citocinas específicas e pela expressão de receptores extracelulares (Campuzano e Wormley, 2018). Com isso, macrófagos M1 são importantes na eliminação do patógeno fúngico e apresentam como marcadores óxido nítricosintase induzida (iNOS ou NOS2); enquanto que macrófagos M2 são responsáveis pela proliferação do patógeno e persistência da doença, tendo como marcadores desse fenótipo 
Arginase-1 (Arg-1), Fizz1 e uma molécula semelhante a quitinase (YM1) (Murray e Wynn, 2011).

Além dos marcadores específicos, a polarização dos macrófagos para um fenótipo M1 ou M2 é dependente da presença de citocinas do microambiente durante a infecção (Davis et al., 2013), sendo que para a ativação de macrófagos M1 é necessário um perfil de citocinas dependente de IFN- $\gamma$, enquanto que IL-4 e/ou IL-13 conduz para o desenvolvimento de macrófagos M2 (Arora et al., 2011; Hardison et al., 2012).

Os patógenos também podem ser reconhecidos por células dendríticas (CDs) que são células sentinelas do sistema imune e apresentadora de antígenos profissionais (APCs) promovendo uma ligação entre a resposta imune inata e a adaptativa (Leopold Wager et al., 2016; Heung, 2017). Essas células estão presentes nas vias aéreas e após a fagocitose do patógeno, estes serão compartimentalizados dentro do fagolisossomo e degradados por mecanismos oxidativos e não- oxidativos (Wozniak e Levitz, 2008).

As DCs sofrem aumento na expressão de moléculas coestimulatórias como CD40, CD80 e CD86, e após sua maturação são responsáveis pela apresentação de antígenos para as células T naive através do complexo principal de histocompatibilidade II (MHCII) (Bauman et al., 2000). A ativação de uma resposta imune Th1 consiste em uma resposta pró - inflamatória associada à proteção contra criptococose. Sua ativação leva a produção de citocinas como IFNy; interleucina 2 (IL-2) e IL-12. Já a ativação de uma resposta Th2, anti-inflamatória, está associada com a produção de citocinas como IL-4, IL-5 e IL-13 conduzindo para uma resposta não protetora com favorecimento da exacerbação da doença. Por sua vez, a resposta Th17 está associada com uma resposta imune antifúngica mais especifica com produção de IL-6, IL-17A, IL-21, IL-22 e TGF- $\beta$ (Campuzano e Wormley, 2018).

$\mathrm{Na}$ presença de IFN-y, a maturação de CDs resulta na produção de citocinas próinflamatórias como IL-12 e conduz para uma resposta Th1 (Vieira et al., 2000), enquanto que a expressão de CD86 com OX40L induz a um perfil de resposta Th2 com produção de citocinas anti- inflamatórias como IL-4, IL-5 e IL-13 (Wozniak et al., 2006). Portanto, a ativação de células $\mathrm{T}$ fornece sinais para a produção de citocinas efetoras que irão conduzir para um perfil de resposta Th1 ou Th2 (Campuzano e Wormley, 2018).

Em suma, o sistema imune inato é voltado para eliminação e morte de patógenos, remoção e prevenção de danos teciduais e ativação da imunidade adaptativa. Sendo assim, seu mau funcionamento pode resultar em maior susceptibilidade à patógenos ou gerar doenças inflamatórias e autoimunes (Campuzano e Wormley, 2018). 


\section{OBJETIVOS}

Apesar do grande número de estudos sobre a complexa diversidade das propriedades estruturais, bioquímicas e funcionais de Galectina-3, existe pouca informação disponível sobre sua distribuição nos tecidos e padrão de expressão em murinos normais e/ou tecidos humanos, além do seu envolvimento na infecção por Cryptococcus spp.

\subsection{Objetivo Geral}

Dentro do exposto e dado o envolvimento desta proteína ligante de carboidratos em uma variedade de processos intracelulares e extracelulares, a presente dissertação tem como objetivo avaliar o papel de Gal-3 sobre o curso da infecção experimental por Cryptococcus neoformans.

\subsection{Objetivos Específicos}

I. Comparar a sobrevivência à infecção por C. neoformans, de animais Gal-3 KO com animais WT;

II. Avaliar os perfis de citocinas no pulmão, baço e cérebro de camundongos WT e Gal-3 KO infectados com C. neoformans;

III. Análise histopatológica do baço, pulmão e cérebro dos animais Gal-3 KO infectado, comparando com animais WT;

IV. Analisar comparativamente o perfil gênico da imunidade inata do hospedeiro, durante a criptococose, por arranjo de PCR em tempo real (PCR Array), da modulação de genes relacionados a resposta antifúngica, bem como adicionalmente comparar com a modulação gênica do animal Gal-3 KO infectado por C. neoformans. 


\section{MATERIAIS E MÉTODOS}

\subsection{Condições de crescimento de $C$. neoformans}

Linhagens de C. neoformans H99 (sorotipo A) foram cultivadas por $72 \mathrm{~h}$ em meio mínimo composto de glicose (15 mM), $\mathrm{MgSO}_{4}(10 \mathrm{mM}), \mathrm{KH}_{2} \mathrm{PO}_{4}(29.4 \mathrm{mM})$, glicina (13 mM), e tiamina- $\mathrm{HCl}$ (3 M). Células fúngicas foram cultivadas a temperatura ambiente por $48 \mathrm{~h}$, com agitação contínua de 190 rpm.

\subsection{Animais}

Foram utilizados camundongos da linhagem C57BL/6 tipo selvagem e galectina-3 knockout (Gal- $3 \mathrm{KO}$ ), machos, entre 6 e 8 semanas de idade, provenientes do biotério de criação de animais isogênicos da Faculdade de Medicina de Ribeirão Preto (FMRP-USP). Todos os procedimentos realizados com os animais estão de acordo com os princípios propostos pelo Colégio Brasileiro de Experimentação Animal - COBEA. O projeto está aprovado pelo comitê de ética da FMRP-USP, com número de protocolo 100/2015.

\subsection{Preparação de inóculo para infecção}

Para infecção experiemental em camundongos (C57BL/6 tipo selvagem ou Gal-3 knockout), as células fúngicas foram crescidas em meio Sabouraud até a fase logarítimica, lavadas e suspensas em PBS, com posterior determinação da concentração celular em hemocitometro. As células fúngicas suspensas em PBS tiveram a densidade celular ajustada para $10^{6}$ células fungicas $/ \mathrm{ml}$, e o inóculo foi realizado via intratraqueal no volume de $50 \mu 1$. O inóculo foi confirmado por plaqueamento em meio ágar Sabouraud, seguido por contagem de CFU ( unidades formadoras de colônias).

\subsection{Curva de sobrevida}

Os camundongos WT e Gal-3 KO foram anestesiados com xilazina (125 mg/kg) e ketamina $(10 \mathrm{mg} / \mathrm{kg})$ em PBS, e seus pescoços foram hiperextendidos e sua traqueia foi exposta após a incisão. $\mathrm{O}$ inóculo de $1 \times 10^{5}$ células de levedura foi realizado para análise da 
sobrevivência de camundongos WT e Gal-3 KO com monitoramento diário quanto à sua mortalidade.

\subsection{Carga fúngica dos órgãos}

Os inóculos de $5 \times 10^{5}$ e $10^{6}$ células foram realizados para determinação da carga fúngica e análise dos niveis de citocinas, respectivamente, no cérebro, pulmão e baço dos animais WT e Gal-3 KO, em 3, 7 e 14 dias após a infecção. A carga fúngica foi determinada pelo número de unidades formadoras de colônias (CFU) dos órgãos após plaquemaneto. Os camundongos infectados foram sacrificados, e pulmão e cérebro removidos e homogeneizados em PBS estéril. Alíquotas de $100 \mu \mathrm{L}$ foram plaqueadas em meio ágar Sabouraud e após dois dias de incubação a $30^{\circ} \mathrm{C}$, o número de colônias foram contadas e a concentração de leveduras/ml foram calculadas. Esses valores foram relacionados a massa dos órgãos e a carga de $C$. neoformans para cada órgão foi expressa em $\mathrm{CFU} / \mathrm{ml} / \mathrm{mg}$ de tecido.

\subsection{Perfis de citocinas no pulmão, baço e cérebro nos camundongos com criptococose}

Os fragmentos do pulmão, baço e cérebro foram assepticamente retirados, pesados, divulsionados em homogeneizador de tecidos (IKA®- Werke) em frascos contendo PBS estéril $(\mathrm{pH} 7,2)$ e posteriormente, $100 \mu \mathrm{L}$ do macerado de cada um dos órgãos dos animais foram semeados, em duplicata, em placas de Petri contendo meio BHI- ágar (Hyclone, Utah,USA) e $96 \mu \mathrm{g} / \mathrm{ml}$ de gentamicina (Gibco BRL, Life Technologies, Inc.). As placas foram mantidas a $36{ }^{\circ} \mathrm{C}$, por até 4 dias, para o crescimento das colônias. A recuperação do fungo nos órgãos foi avaliada a partir da contagem de CFU aos dois e quatro dias de cultivo, sendo que o número de CFU foi determinado por grama de órgão (CFU/g). Após a homogeneização dos tecidos, o sobrenadante foi aliquotado para a dosagem de citocinas. Essa dosagem do homogeneizado do pulmão, baço e cérebro foi realizada por ensaio imunoenzimático (ELISA) utilizando o Kit OptEIAtm (Pharmingen, San Diego, CA, USA), conforme as instruções do fabricante. As citocinas dosadas foram: IFN- $\gamma$, IL-12p40, IL-10, IL-6, IL-17A, IL-23 e TNF- $\alpha$. As concentrações de citocinas foram determinadas a partir de curvas padrão, utilizando citocinas recombinantes murinas. A absorbância foi lida a $450 \mathrm{~nm}$ no espectrofotômetro de microplatas

(Power Wave-X; BioTek Instruments, Inc.,Winooski, VT, EUA). As concentrações de citocinas foram relacionadas à massa dos órgãos, sendo expressas em pg/ml/mg. 


\subsection{Análise Histopatológica}

Para a realização da análise histopatológica, foram separados fragmentos do pulmão, baço e cérebro e posterior processamento. Os fragmentos foram fixados em methacarn, desidratados em uma série de álcool etílico, diafanizados em xilol e embebidos em parafina. Os cortes seriados apresentaram espessura de $5 \mu \mathrm{m}$. Tecidos foram corados com hematoxilina e eosina (H\&E). Para cada grupo controle e experimental, foram analisadas cinco lâminas por órgão.

\subsection{Análise da modulação gênica por arranjo de PCR em tempo real (PCR Array)}

Os animais WT e Gal-3 KO foram anestesiados com xilazina (125 mg/kg) e ketamina $(10 \mathrm{mg} / \mathrm{kg})$ em PBS e, posteriormente foram infectados, via intratraqueal, com o inóculo de $10^{6}$ leveduras $/ \mathrm{ml}$, no volume de $50 \mu \mathrm{L}$. Os animais do grupo controle receberam administração de PBS. Após sete dias de infecção, os fragmentos do pulmão, baço e cérebro foram retirados assepticamente e divulsionados em homogeneizador de tecidos (IKA® T10 basic homogenizer). O RNA total foi extraído do homogeneizado do pulmão, baço e cérebro, utilizando o reagente TRIzol ( Invitrogen Corporation- Califórnia, EUA), de acordo com as instruções do fabricante. A eluição e a quantificação do RNA total foi realizada através das leituras de absorbâncias de RNA (A260/A280 e A260/A230), determinadas por espectrofotômetro (NanoDrop, Thermo Fisher Scientific - Wilmington, Delaware,EUA). A integridade do RNA foi avaliada através de eletroforese, utilizando gel denaturante de agarose (1\%), verificando a presença das bandas $28 \mathrm{~S}$ e $18 \mathrm{~S}$. O cDNA (DNA complementar) foi sintetizado a partir de $1 \mu \mathrm{g}$ de RNA por amostra utilizando o Kit ImProm-II ${ }^{\mathrm{TM}}$ Reverse Transcription System (Promega Corp., Fitchburg, WI), baseado no uso de transcriptase reversa e ciclagem de temperatura. Para o arranjo de genes, foi utilizado o Kit RT² Profiler PCR Array - Mouse Antifungal Response (Cat. n PAMM-147Z). Este arranjo consiste em uma placa contendo 84 primers liofilizados para alvos gênicos (citados abaixo) relacionados com a resposta imune inata ao fungo, além de controles negativos, de DNA genômico e primers para seis diferentes genes constitutivos. Um pool de cDNA proveniente da etapa anterior foi adicionado em solução contendo tampão, polimerase, SYBR green Mastermix (2X RT ${ }^{2}$ SYBR Green Mastermix, SABiosciences- Qiagen) e água, e dividido entre os 96 poços da placa (volume de $25 \mu \mathrm{L}$ ). A PCR em tempo real foi processada em termociclador BioRad CFX 96 (C1000 ${ }^{\mathrm{TM}}$ termal Cycler). Para a análise dos resultados, os valores de $\mathrm{Ct}$ (ciclo limiar) obtidos, 
foram transferidos para o software SABiosciences Web disponibilizados pela Qiagen através da área de Data Analysis Center fornecida pelo próprio site da fabricante.

Lista dos genes utilizados pelo PCR Array - Mouse Antifungal Response:

\section{Receptores de reconhecimento padrão (PRRs) fúngico}

Responsivo a Beta-glucana: Cd36, Cd5, Clec7a (dectina), Itgam, Itgb2, Scarf1, Tlr2.

Responsivo a Manose/quitina: Cd207, Cd209a, Chia1, Clec4n, Mrc1, Tlr2, Tlr4. Outros receptores de reconhecimento padrão (PRRs) fúngico: Colec12, Nlrp3, Nptx1, Ptx3, Tlr9.

\section{Transducão de sinal}

Sinalização de Dectina-1: Bc110, Card9, Clec7a (Dectina 1), Malt1, Plcg2, Raf1, Syk (Sykb)

Sinalização de NFK $\beta$ : Bcl10, Card9, Casp1 (ICE), Casp8 (FLICE), Cd40 (Tnfrsf5), Ikbkb (IKKbeta), Il10, Il1b, Irak4, Malt1, Map3k7 (Tak1), Nfkb1, NfKbia (IK $\beta \alpha$, Mad3), Stat1, Tnf.

Sinalização de Receptor Toll-Like (TLR): Casp8 (FLICE), Cd14, Fos, Irak1, Itgb2, Jun, Map2k4 (Mkk4, Jnkk1), Map3k7 (Tak1), Mapk14 (p38alpha), Mapk8 (JNK1), Myd88, NfKß, tirap, Tlr2, Tlr4, Tlr9, Traf6.

Sinalização do complemento: C3, C5ar1 (Gpr77), Itgam, Itgb2, Mb12, Syk (Sykb).

Sinalização dos receptores NOD-Like (NLR): Card9, Casp1 (ICE), Nlrp3, Pycard (Tms1, Asc).

\section{Inflamação}

C3, Cc112 (MCP-5, Scya12), Ccl20 (MIP-3A), Ccl5 (RANTES), Ccr1, Ccr5, Cd14, Cd40 (Tnfrsf5), Clec7a (Dectina 1), Cxcl1 (Gro1), Cxcl10 (INP10), Cxcl11 (Itac, Ip9), Cxcl3, Cxc19 (Mig), F3, Fos, Il10, Il1a, Il1b, Il2, Il23a, Il6, Itgb2, Lyn, Mbl2, Myd88, Nfkb1, Ptgs2 (COX2), Tirap, Tlr2, Tlr4, Tlr9, Tnf.

\section{$\underline{\text { Fagocitose }}$}

C3, Cd14, Cd36, Clec7a (Dectina 1), Colec12, Fcgr1, Fcnb, Mbl2, Sftpd.

\section{Genes responsivos a fungos patogênicos específicos}

Candida albicans: Cc112 (MCP-5, Scya12, Cc120 (MIP-3A), Ccl5 (RANTES), Ccr1, Cd14, Cd209a, Cd83, Clec4n, Clec7a (Dectina1), Csf2 (G MCSF), Csf3 (Gcsf), Cxcl1 (Gro1), Cxcl10 
(INP10), Cxcl11 (Itac, Ip9), Cxcl3, Cxc19 (Mig), Fcgr1, Fcgr4, Ifng, Il12b, Il18, Il1a, Il1b, Il1r, Il13a, Il6, Myd88, Nfkb1, Ptgs2 (COX2), Socs3, Tlr2, Tnf.

Aspergillus fumigatus: C3, Casp1 (ICE), Casp8 (FLICE), Ccl12 (MCP-5, Scya12), Ccl20 (MIP-3A), Ccl5 (RANTES), Ccr1, Ccr5, Cd14, Cd40 (Tnfrsf5), Cd83, Clec4n, Clec7a (Dectina1), Csf2 (GMCSF), Csf3 (Gcsf), Cxcl1 (Gro1), Cxcl10 (INP10), Cxcl11 (Itac, Ip9), Cxcl3, Cxc19 (Mig), F2r11 (Par2), F3, Fcgr1, Fcgr3, Fcnb, Ifng, Il10, Il12a, Il12b, Il18, Il1a, Il1b, Il1r1, Il6, Jun, Malt1, Mapk14 (p38alpha), Mb12, Myd88, Nfkbia (Ikba, Mad3), Ptgs2 (COX2), Ptpn6, Ptx3, Sftpd, Socs3, St3gal5, Stat1, Syk (Sykb), Tlr2, Tlr4, Tlr9, Tnf.

Cryptococcus neoformans: C3, Cd5, Ccl12 (MCP-5, Scya12), Cd40 (Tnfrsf5), Socs3.

\subsection{Análise estatística}

Os resultados foram expressos em média \pm EPM (erro padrão da média). Todas as análises estatísticas e comparações foram realizadas utilizando o software GraphPad Prism versão 6.0 (Graph Pad Software, San Diego, CA). Nas análises entre dois grupos experimentais foi utlizado o teste t-Student. O teste log rank foi utilizado para comparar as taxas de sobrevida entre os grupos de estudo. Um valor de $\mathrm{p}<0,05$ foi considerado estatisticamente significativo. Para análise de PCR Array, os valores de Ct foram normalizados através do método de seleção automático, onde seleciona-se um dos cinco genes constitutivos presentes na placa de PCR Array (Gusb, Hprt1, Hsp90ab1, Gadph and Actb) que apresentaram expressão mais estáveis entre os grupos experimentais e controle. Os valores de Ct são geometricamente calculados e utilizados para o cálculo de $2^{-\Delta \Delta \mathrm{Ct}}$. As diferenças dos níveis de transcritos ou Fold change (FC) entre os grupos experimentais e controle foram determinadas através do método de comparação do $\mathrm{Ct}$, baseado no algoritimo $2^{-\Delta \Delta \mathrm{Ct}}$. Os genes foram determinados significativamente modulados (induzidos ou reprimidos) através do cut off $=2$, em que a diferença do FC na média dos valores de $2^{-\Delta \Delta \mathrm{Ct}}$ foi maior que 2 ou menor que -2 . 


\section{RESULTADOS}

\subsection{Ausência de Gal-3 promove maior suscetibilidade a infecção por $C$. neoformans}

Devido a observação prévia de elevados níveis séricos de Gal-3 em camundongos infectados com C. neoformans, propomo-nos, primeiramente, a comparar a sobrevida e a carga fúngica de animais Gal-3 KO e WT, infectados com C. neoformans. Observamos que animais Gal-3 KO apresentaram menor curva de sobrevida quando comparado aos animais WT. Os animais morreram aproximadamente no $17^{\circ}$ e $22^{\circ}$ dia pós-infecção, respectivamente (Fig. 1A). Esses resultados foram corroborados com a quantificação da carga fúngica (por CFU) no pulmão e cérebro de ambos os grupos de animais. Nota-se um aumento da carga fúngica nos pulmões, após 3, 7 e 14 dias de infecção, dos animais Gal-3 KO quando comparados com os WT. Já no cérebro, há um aumento significativo da carga fúngica nos animais Gal-3 KO em relação aos animais WT após 14 dias de infecção (Fig. 1B).

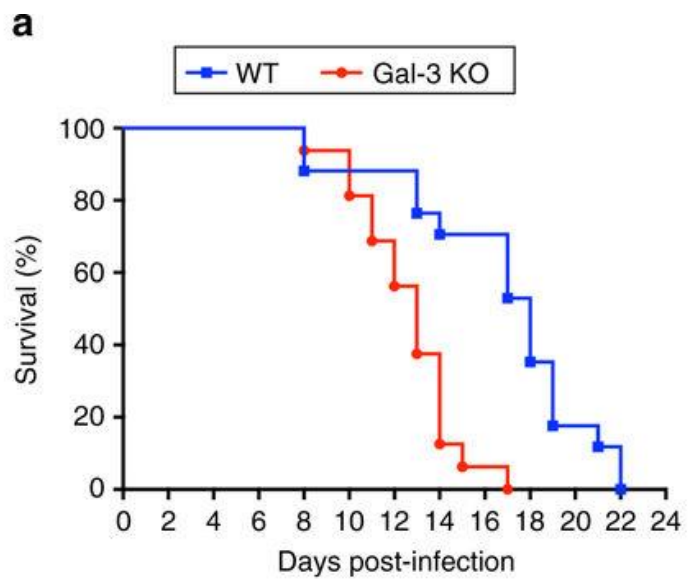

b
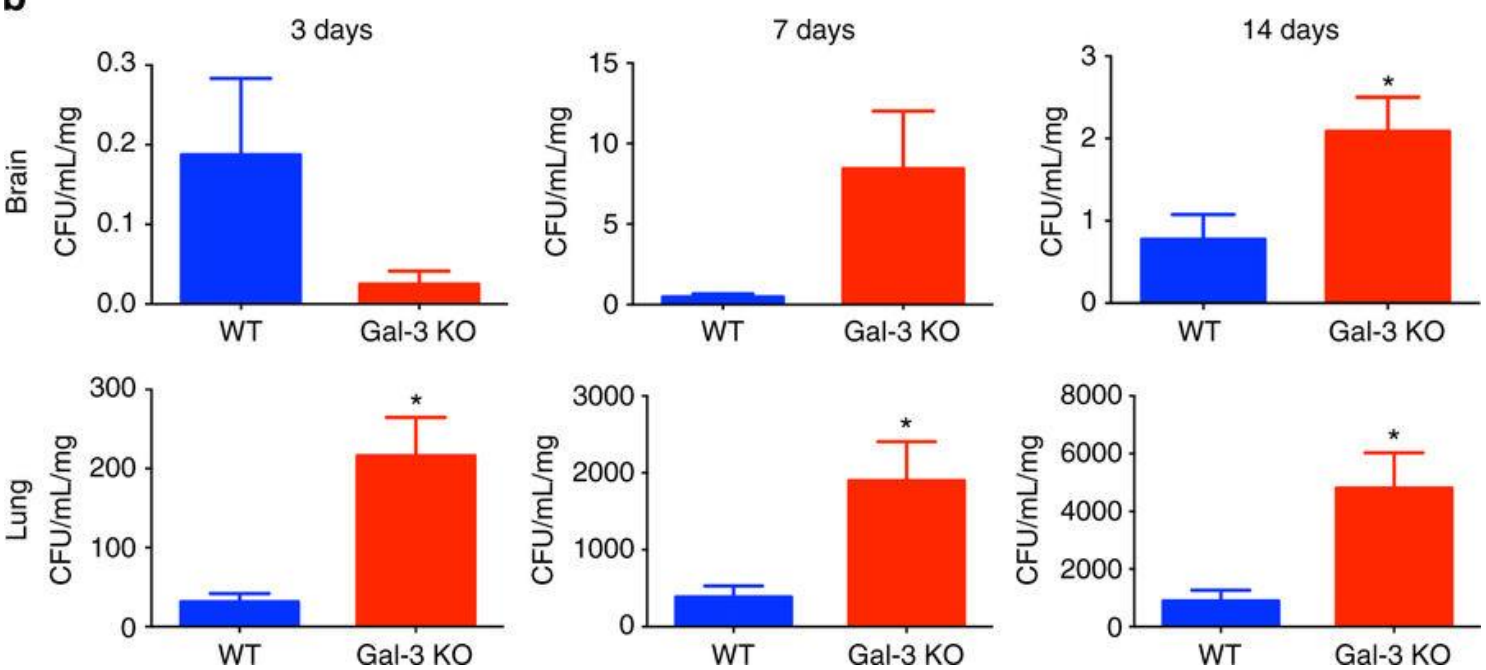
Figura 1. Análise da sobrevida e carga fúngica de animais Gal-3 KO infectados com $C$. neoformans. A sobrevivência (a) de camundongos Gal-3 KO (knockout, linha vermelha) e WT (tipo selvagem, linha azul) foi verificada diariamente após a infecção intratraqueal com $10^{5}$ células de levedura H99. A quantificação da carga fúngica por unidades formadoras de colônia (CFU) (b) no cérebro e pulmão dos animais WT (barra azul) e Gal-3 KO (barra vermelha) foram avaliadas 3, 7 e 14 dias após a infecção por C. neoformans. O eixo y expressa CFU/ml/mg devido a normalização da carga fúngica em relação ao peso do fragmento de cada órgão. As barras representam a média \pm DP das CFU obtidas através de amostras em triplicatas em grupo de oito animais.

$* \mathrm{p}<0.05$, Student's t-test, Gal-3 KO comparado com animais WT.

\subsection{Deficiência de Gal-3 afeta a resposta imune Th17}

A imunidade protetora contra Cryptococcus, depende do reconhecimento, controle e interação adequada com as células da resposta imune inata e adaptativa. Historicamente, as respostas imunes pró-inflamatórias do tipo Th1 estão associadas à proteção contra criptococose, enquanto as respostas imunes do tipo Th2 estão associadas à exacerbação da doença (Campuzano, 2018). O controle ou a erradicação de patógenos fúngicos começa com o reconhecimento e fagocitose da levedura por células fagocíticas da resposta imune inata. Uma vez que a levedura é internalizada dentro do fagossoma, ocorre a fusão fagossomo-lisossomo, resultando na ativação do inflamassoma, acidificação do fagossomo-lisossoma e degradação subsequente da levedura. Além disso, as células fagocíticas produzem espécies reativas de oxigênio (ROS), citocinas e quimiocinas, além de apresentarem antígenos às células $\mathrm{T}$ que, então, direcionam a resposta imune adaptativa (Romani, 2011).

A ativação da resposta imune do tipo Th1 protetora está associada à produção de interferon- $\gamma$ (IFN- $\gamma$ ), interleucina-2 (IL-2) e IL-12. Por outro lado, a resposta do tipo Th2 está associada à produção de citocinas IL-4, IL-5 e IL-13, e estão envolvidas no recrutamento de eosinófilos e na exacerbação da doença. A resposta do tipo Th17 está associada à produção de IL-6, IL-17A, IL-21, IL-22 e fator de crescimento transformador (TGF) - $\beta$ e está associada à resposta imune anti-criptococócica. No entanto, enquanto a IL-17A contribui para a proteção, ela não é fundamental para a proteção e eventual erradicação deste patógeno em camundongos (Campuzano, 2018).

Sabe-se que a imunidade protetora contra a infecção por $C$. neoformans dependente da indução de uma resposta imune do tipo Th1. Na literatura, já existem estudos mostrando que o 
aumento da produção de IL-17A está associada com uma redução da carga criptococócica, sugerindo que IL-17A também possui papel significativo na geração de respostas imunes protetoras anti-criptococócicas (Wozniak et al., 2011).

Neste trabalho, avaliamos se a ausência ou presença de Gal-3 leva a um perfil de resposta imune Th1, Th2 ou Th17 durante a infecção experimental por C. neoformans. Para isso, fragmentos do cérebro, pulmão e baço foram retirados em 3, 7 e 14 dias pós infecção de camundongos WT e Gal-3 KO. Observamos que os níveis de IFN- $\gamma$, IL-12p40, IL-6, TNF- $\alpha$ e IL-10 nos homogenatos de cérebro e pulmão não apresentaram diferenças significativas quando comparado os animais Gal-3 KO com os WT (Fig. 2 A-E, H-L). Já nos homogenatos de baço, os níveis de IL-12p40 e IL-6 foram maiores nos animais WT quando comparados com os Gal$3 \mathrm{KO}$ após 3 e 7 dias de infecção (Fig. 2P, Q), enquanto os níveis de TNF- $\alpha$ só aumentaram no $3^{\circ}$ dia pós-infecção (Fig. 2R). Em contrapartida, os níveis de IFN- $\gamma$ e IL-10 não apresentaram alterações significativas (Fig. 2O, S). Ao analisarmos os níveis de IL-17 e IL-23, verificamos maior concentração nos homogenatos de pulmão dos animais WT quando comparados com Gal-3 KO no $3^{\circ}$ dia pós- infecção (Fig. 2M, N), assim como maior concentração dos níveis de IL-23 nos homogenatos de baço (Fig. 2U) diferentemente dos níveis de IL-17 que permaneceram iguais (Fig. 2T). Nos homogenatos de cérebro, os níveis de IL-17 e IL-23 não apresentaram alterações significativas em todos os períodos de infecção (Fig. 2F, G). 

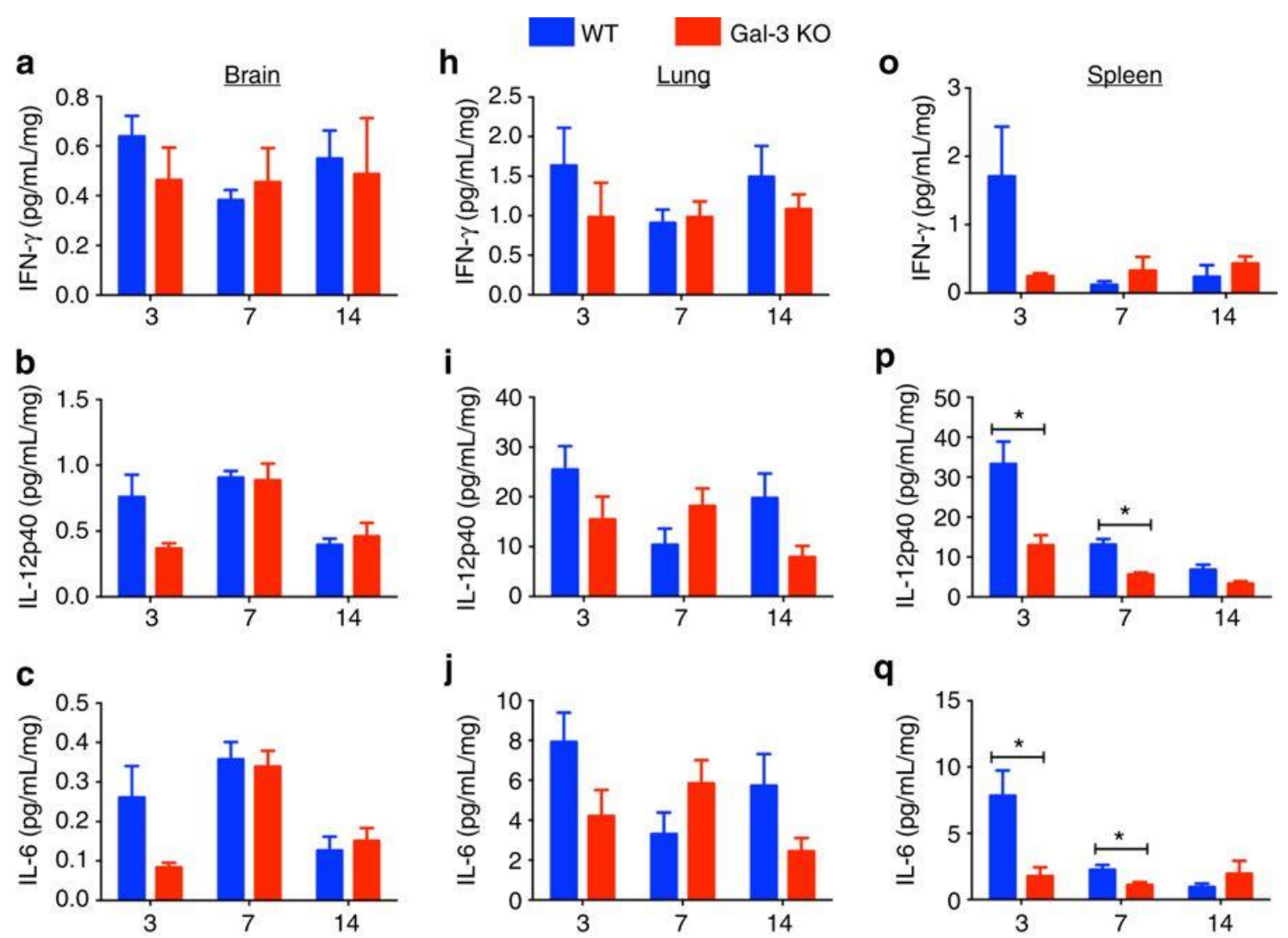

q
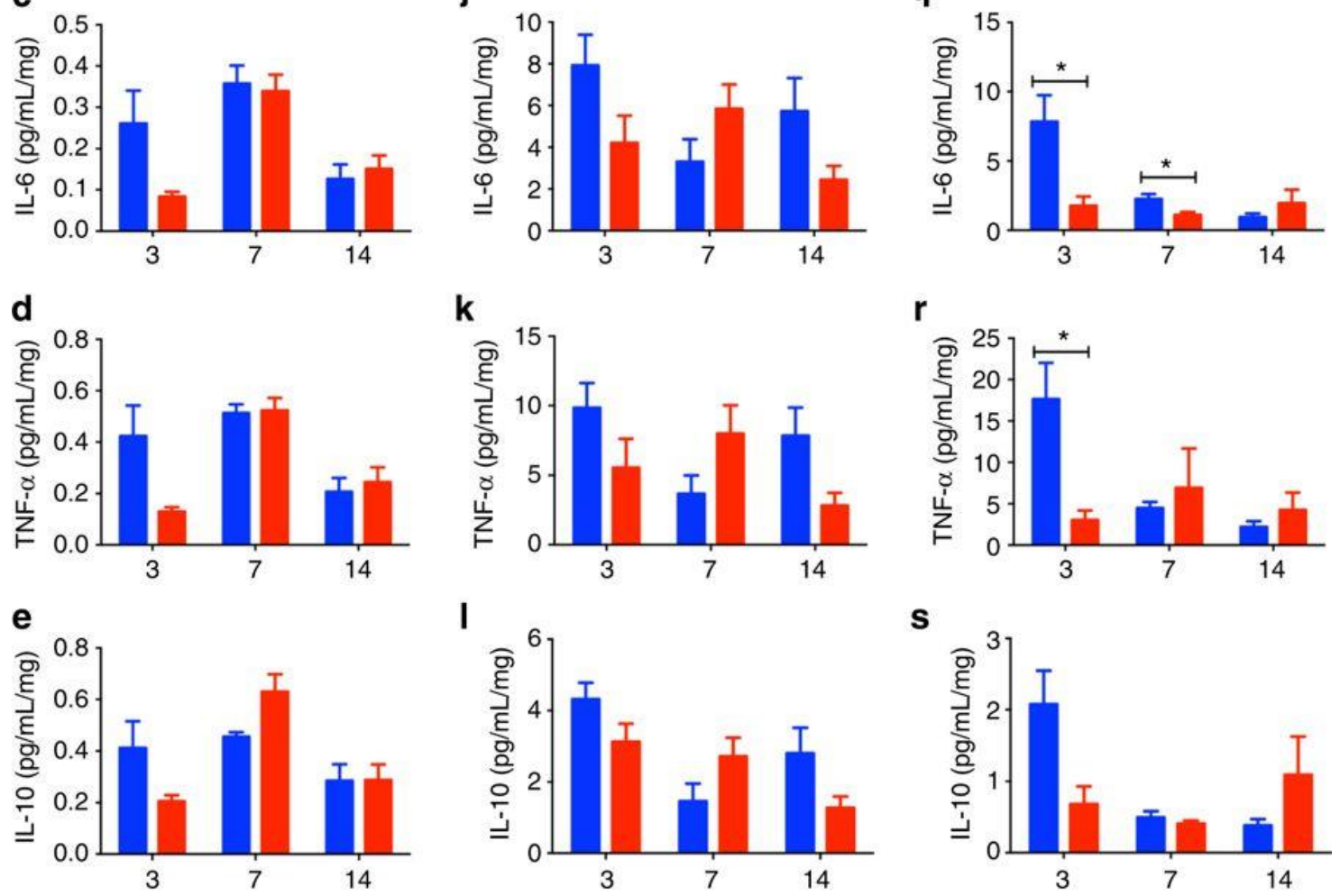

S
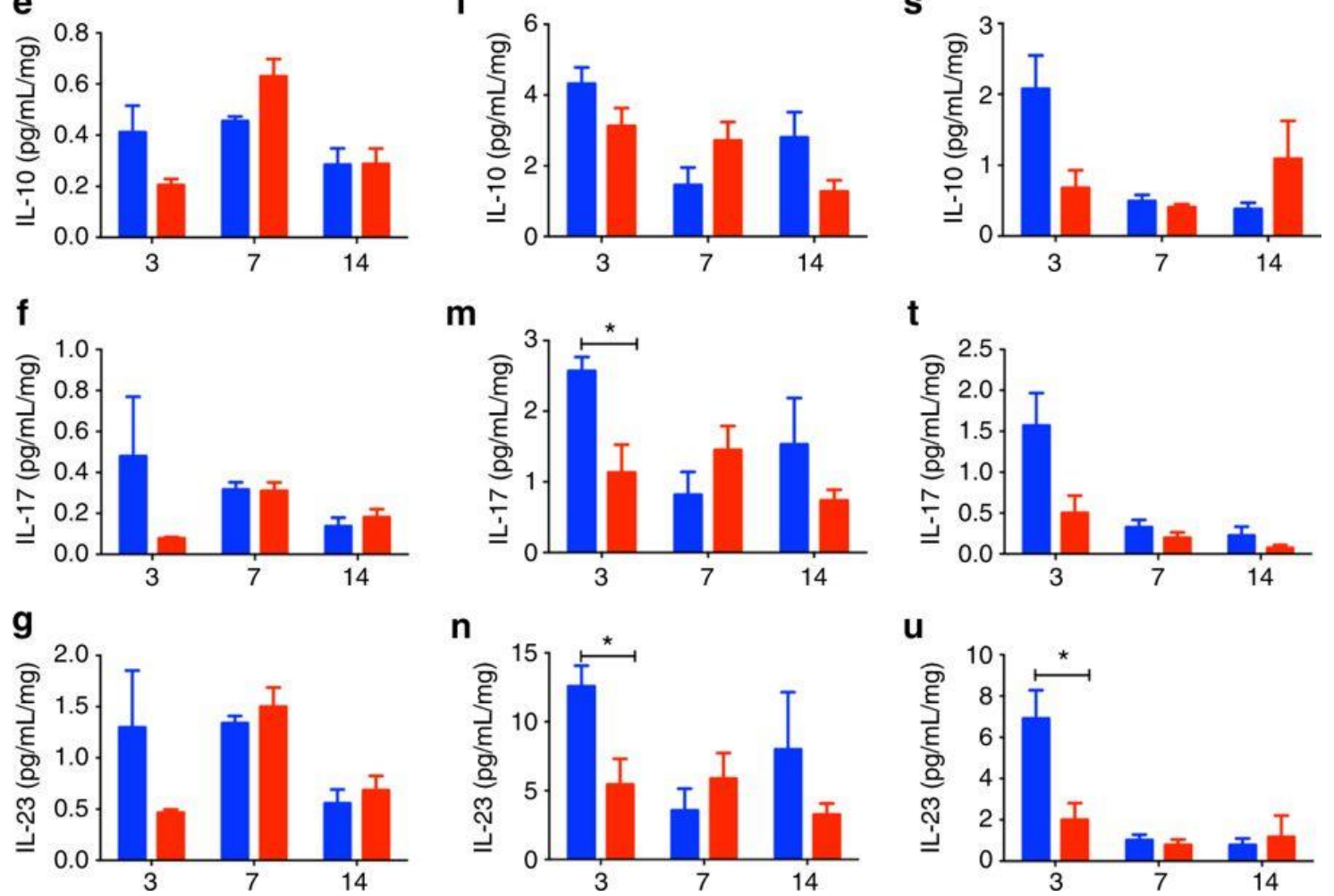
Figura 2. Avaliação do perfil de resposta imune na criptococose experimental. Camundongos WT (tipo selvagem, barras azuis) e Gal-3 KO (knockout, barras vermelhas) foram infectados intratraquealmente com uma suspensão de $50 \mu 1$ contendo $10^{6}$ células de levedura H99. Os fragmentos de pulmão, baço e cérebro foram assepticamente retirados, pesados e divulsionados em homogeneizador de tecidos. Após homogeneização, o sobrenadante foi aliquotado para dosagem de citocinas por ELISA. Os níveis das citocinas (IFN- $\gamma$, IL-12p40, IL-6, TNF- $\alpha$, IL-10, IL-17 e IL-23) no cérebro (A-G), pulmão (H-N) e baço (O-U) foram determinadas 3, 7 e 14 dias após a infecção. Os resultados representam a média \pm DP de cinco camundongos por grupo, em triplicata.

$* \mathrm{p}<0.05$, Student's t-test, Gal-3 KO comparado com animais WT.

\subsection{Avaliação da presença de infiltrados inflamatórios nos tecidos de camundongos WT e Gal-3 KO na presença da infecção por $C$. neoformans}

Para avaliarmos se a ausência de Gal-3 promove a presença de infiltrados inflamatórios nos tecidos, foram realizadas análises histopatológicas do pulmão, baço e cérebro de animais WT e Gal-3 KO durante a infecção por C. neoformans. Esses tecidos foram corados com H\&E e as análises foram realizadas em microscópio Olympus dotado de um sistema de fotodocumentação, no aumento de 20x. Observamos que na ausência da infecção, o pulmão dos animais Gal-3 KO apresentou maior secreção de muco pelo epitélio brônquico quando comparado aos animais WT (Figura 3A e 3B). Durante a infecção por C. neoformans, foi observado moderada eosinofilia peribrônquica no pulmão (Figura 3C e 3D) e discreto desarranjo folicular por ativação linfoide reacional no baço (Figura $3 \mathrm{G} \mathrm{e} 3 \mathrm{H}$ ), tanto nos animais WT como nos animais Gal-3 KO. No baço dos animais WT e Gal-3 KO, na ausência de infecção, não foram observadas alterações (Figura 3E e 3F), assim como não foram visualizadas alterações significativas no cérebro desses animais, tanto na ausência como na presença de criptococose (Figura 3I - L). 

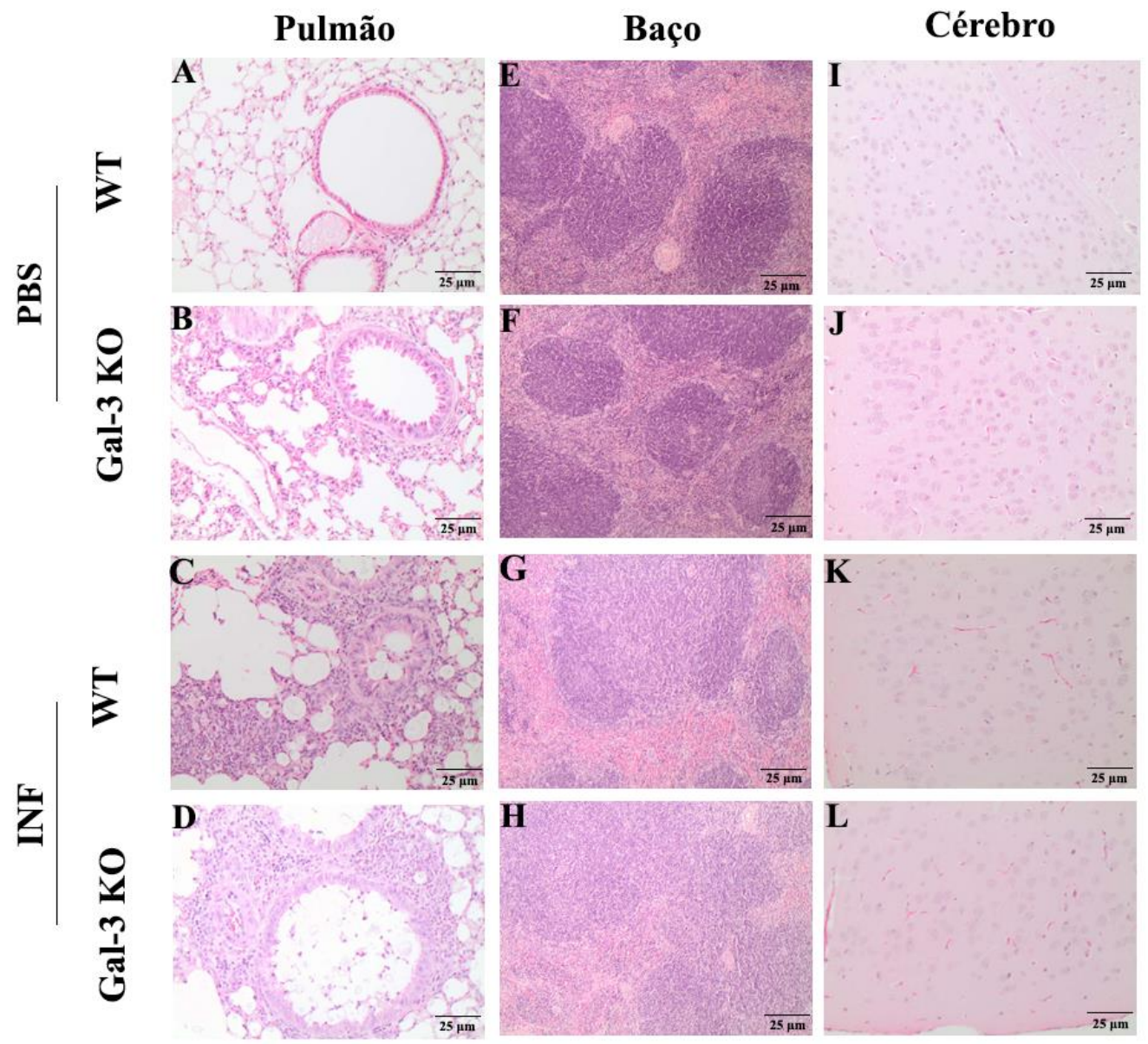

Figura 3. Histopatologia do pulmão, baço e cérebro de animais WT e Gal-3 KO na presença de infecção por $\boldsymbol{C}$. neoformans. As imagens representam secções dos órgãos dos camundongos WT (tipo selvagem) e Gal-3 KO (Knockout), na presença da infecção (INF) por C. neoformans ou não infectados (grupo controle, tratados com PBS). As secções foram coradas com H\&E e as imagens capturadas com microscópio Olympus dotado de sistema de fotodocumentação. Barra de ampliação $=25 \mu \mathrm{m}$ para todos os órgãos.

\subsection{Perfil gênico da imunidade inata de animais WT e Gal-3 KO durante a criptococose}

A infecção causada por C. neoformans acomete, principalmente, órgãos como pulmão, baço e cérebro. Como demostrado acima, há aumento da carga fúngica nesses órgãos nos animais Gal-3 KO quando comparados com animais WT após 7 dias de infecção (Figura 1B). Diante de tais resultados, propomo-nos a analisar a expressão de genes envolvidos na imunidade 
inata antifúngica no pulmão, baço e cérebro, de animais WT e Gal-3 KO após sete dias de infecção por meio de PCR Array.

4.4.1. Modulação positiva da expressão gênica no pulmão, baço e cérebro de animais WT e Gal-3 KO na presença e ausência da infecção por C. neoformans

Ao analisarmos a expressão gênica responsiva referente a imunidade antifúngica no pulmão, 19 dos 84 genes avaliados, tiveram níveis de transcritos significativamente elevados no pulmão (Tabela 1). Observamos que a infecção causada por $C$. neoformans promove a superexpressão de 13 dos 19 genes envolvidos na imunidade inata tanto na presença como na ausência de Gal-3 quando comparado aos seus respectivos grupos controles (WT PBS e Gal-3 KO PBS). Além disso, foi possível observar que IL-10 apresentou-se exclusivamente modulada no animal WT infectado, enquanto que a ausência de Gal- 3 durante a infecção promoveu a superexpressão de Fcgr1, IFN-y, IL-1 $\alpha$ e IL-1 $\beta$, quando comparados aos seus grupos controles (Figura 4A e 4B)

Quando direcionamos nossas análises para verificar se, durante a infecção fúngica, a ausência de Gal-3 promove aumento da expressão dos genes analisados em relação ao animal WT, observamos modulação positiva para IFN-y e das quimiocinas Cxc19, Cxcl10 e Ccl12 (Figura 4D). Ao realizarmos essa mesma comparação, mas na ausência da infecção fúngica, observamos alteração somente no gene que codifica a lectina de ligação à manose 2 (Mbl2) com fold change de 4,56 (Figura 4C).

Em relação ao baço, pode-se inferir que entre os genes da imunidade inata analisados, nove apresentaram alterações significativas em seus níveis de expressão (Tabela 2). Foi observado aumento significativo da expressão de receptor de quimiocina de motivo C-C (Ccr5) e de receptor de reconhecimento padrão de manose tipo 1C (Mcr1), nos animais WT infectados comparado ao seu grupo controle (Figura 4E). Esses genes, juntamente com TLR9, também estiveram significativamente modulados no animal Gal-3 KO comparado ao animal WT, ambos sem infecção (Figura 4G). Por sua vez, os animais Gal-3 KO infectados quando comparados ao seu grupo controle (Gal-3 KO PBS) e ao grupo WT infectado, apresentaram em comum, alterações no gene codificador da enzima quitinase (Chia1) e na proteína D associada a surfactante (Sftpd). Já Fcnb, Mapk14 e St3gal5 foram exclusivamente modulados quando comparado ao grupo controle, enquanto Scarf1 teve aumento de sua expressão quando comparado ao WT infectado (Figura 4F e 4H).

Dentre os três órgãos analisados, o cérebro apresentou maior aumento da expressão dos genes envolvidos na resposta imune inata antifúngica. Foi possível observar a superexpressão 
de 38 dos 84 genes analisados (Tabela 3). Desses 38 genes, 26 e três correspondem aos animais WT e Gal-3 KO infectados, respectivamente, comparados aos seus grupos controles (Figura 4I e 4J). Ademais, 16 genes (C3, Casp1, Ccl12, Ccl5, CD209a, CD36, Clec4n, Clec7a, Csf2, Cxc110, IL-12 $\beta$, IL-1 $\beta$, IL-2, Mbl2, Ptx3 e Sftpd) foram significativamente transcritos em animais Gal-3 KO comparado com animais WT, não infectados (Figura 4K), enquanto que o animal Gal-3 KO infectado comparado ao animal WT infectado, promoveu a superexpressão de Fos, IL-23A, Mb12 e Sftpd (Figura 4L).

Tabela 1. Aumento da expressão de genes da resposta imune inata no pulmão de camundongos WT e Gal-3 KO, na ausência e presença da infecção por C. neoformans.

\begin{tabular}{|c|c|c|c|c|c|c|}
\hline Gene & Descrição & RefSeq & $\begin{array}{c}\text { WT } \\
\text { CTRL/ INF }\end{array}$ & $\begin{array}{c}\text { KO } \\
\text { CTRL/ INF }\end{array}$ & $\begin{array}{c}\text { WT/ KO } \\
\text { CTRL }\end{array}$ & $\begin{array}{c}\text { WT/ KO } \\
\text { INF }\end{array}$ \\
\hline Ccl12 & $\begin{array}{l}\text { Quimiocina (motivo } \\
\text { C-C) ligante } 12\end{array}$ & NM_011331 & 4,21 & 11,39 & - & 2,33 \\
\hline Ccr1 & $\begin{array}{l}\text { Quimiocina (motivo } \\
\text { C-C) receptor } 1\end{array}$ & NM_009912 & 2,99 & 2,89 & - & - \\
\hline Ccr5 & $\begin{array}{l}\text { Quimiocina (motivo } \\
\text { C-C) receptor } 5\end{array}$ & NM_009917 & 3,12 & 6,02 & - & - \\
\hline Chial & Quitinase & NM_023186 & 7,79 & 4,26 & - & - \\
\hline Clec7a & $\begin{array}{c}\text { Lectina tipo } \mathrm{C} \text {, } \\
\text { família } 7 \text {, membro a }\end{array}$ & NM_020008 & 4,12 & 4,11 & - & - \\
\hline Cxc1 & $\begin{array}{l}\text { Quimiocina (motivo } \\
\text { C-X-C) ligante } 1\end{array}$ & NM_008176 & 3,61 & 3,01 & - & - \\
\hline Cxcl10 & $\begin{array}{l}\text { Quimiocina (motivo } \\
\text { C-X-C) ligante } 10\end{array}$ & NM_021274 & 2,25 & 22,16 & - & 2,69 \\
\hline Cxcl3 & $\begin{array}{c}\text { Quimiocina (motivo } \\
\text { C-X-C) ligante } 3\end{array}$ & NM_203320 & 6,46 & 13,64 & - & - \\
\hline Cxcl9 & $\begin{array}{c}\text { Quimiocina (motivo } \\
\text { C-X-C) ligante } 9\end{array}$ & NM_008599 & 10,21 & 21,11 & - & 2,23 \\
\hline Fcgr1 & $\begin{array}{l}\text { Receptor } \mathrm{Fc}, \mathrm{IgG} \text {, } \\
\text { alta afinidade I }\end{array}$ & NM_010186 & - & 2,22 & - & - \\
\hline Fcgr3 & $\begin{array}{l}\text { Receptor Fc, IgG, } \\
\text { baixa afinidade III }\end{array}$ & NM_010188 & 2,89 & 3,53 & - & - \\
\hline$I F N-y$ & Interferon gama & NM_008337 & - & 2,6 & - & 3,05 \\
\hline$I L-10$ & Interleucina 10 & NM_010548 & 3,19 & - & - & - \\
\hline$I L-1 \alpha$ & Interleucina 1 alfa & NM_010554 & - & 2,93 & - & - \\
\hline$I L-1 \beta$ & Interleucina 1 beta & NM_008361 & - & 2,36 & - & - \\
\hline$I L-6$ & Interleucina 6 & $\begin{array}{c}\text { NM_001314 } \\
054\end{array}$ & 8,01 & 19,84 & - & - \\
\hline
\end{tabular}


Mbl2

Lectina ligadora de manose (Proteína C)

NM_010776

4,56

Mrc1

2

Receptor de manose, C, tipo 1

NM_008625

3,44

2,68

Ptx3

Pentraxina

NM_008987

2,47

2,48

Tabela 2. Aumento na expressão gênica no baço de camundongos WT e Gal-3 KO, na ausência e presença da infecção por C. neoformans.

\begin{tabular}{|c|c|c|c|c|c|c|}
\hline Gene & Descrição & RefSeq & $\begin{array}{c}\text { WT } \\
\text { CTRL/ INF }\end{array}$ & $\begin{array}{c}\text { KO } \\
\text { CTRL/ INF }\end{array}$ & $\begin{array}{c}\text { WT/ KO } \\
\text { CTRL }\end{array}$ & $\begin{array}{c}\text { WT/ KO } \\
\text { INF }\end{array}$ \\
\hline Ccr5 & $\begin{array}{l}\text { Quimiocina (motivo } \\
\text { C-C) receptor } 5\end{array}$ & NM_009917 & 12,38 & - & 11,08 & - \\
\hline Chial & Quitinase & NM_023186 & - & 11,16 & - & 3,73 \\
\hline Fcnb & Ficolin B & NM_010190 & - & 2,43 & - & - \\
\hline Mapk14 & Map quinase 14 & NM_011951 & - & 2,01 & - & - \\
\hline Mrc1 & $\begin{array}{l}\text { Receptor de manose, } \\
\text { C, tipo } 1\end{array}$ & NM_008625 & 2,35 & - & 2,16 & - \\
\hline Scarf1 & $\begin{array}{l}\text { Receptor scavenger } \\
\text { classe F, tipo } 1\end{array}$ & $\begin{array}{c}\text { NM_001004 } \\
157\end{array}$ & - & - & - & 2,53 \\
\hline Sftpd & $\begin{array}{l}\text { Proteina D associada } \\
\quad \text { a surfactante }\end{array}$ & NM_009160 & - & 10,06 & - & 3,68 \\
\hline St3gal5 & $\begin{array}{c}\text { ST3 } \beta \text {-galactosídeo } \\
\alpha-2,3- \\
\text { sialiltransferase } 5\end{array}$ & NM_011375 & - & 3,07 & - & - \\
\hline TLR9 & Receptor Toll 9 & NM_031178 & - & - & 2,1 & - \\
\hline
\end{tabular}

Tabela 3. Superexpressão gênica no cérebro de camundongos WT e Gal-3 KO na ausência e presença da infecção por $C$. neoformans.

\begin{tabular}{|c|c|c|c|c|c|c|}
\hline Gene & Descrição & RefSeq & $\begin{array}{c}\text { WT } \\
\text { CTRL/INF }\end{array}$ & $\begin{array}{c}\text { KO } \\
\text { CTRL/INF }\end{array}$ & $\begin{array}{c}W T / K O \\
C T R L\end{array}$ & $\begin{array}{c}W T / K O \\
I N F\end{array}$ \\
\hline$C 3$ & $\begin{array}{l}\text { Complemento } \\
\text { componente } 3\end{array}$ & NM_009778 & 6,61 & - & 2,33 & - \\
\hline C5ar1 & $\begin{array}{c}\text { Complemento } \\
\text { componente } 5 \mathrm{~A} \text {, } \\
\text { receptor } 1\end{array}$ & NM_007577 & 2,56 & - & & - \\
\hline Casp1 & Caspase 1 & NM_009807 & - & - & 2,39 & - \\
\hline
\end{tabular}




\begin{tabular}{|c|c|c|c|c|c|c|}
\hline Ccl12 & $\begin{array}{c}\text { Quimiocina } \\
\text { (motivo C-C) } \\
\text { ligante } 12\end{array}$ & NM_011331 & 45,41 & - & 3,13 & - \\
\hline Ccl5 & $\begin{array}{c}\text { Quimiocina } \\
\text { (motivo C-C) } \\
\text { ligante } 5\end{array}$ & NM_013653 & 3,9 & - & 2,56 & - \\
\hline Ccrl & $\begin{array}{l}\text { Quimiocina } \\
\text { (motivo C-C) } \\
\text { receptor } 1\end{array}$ & NM_009912 & 6,75 & - & - & - \\
\hline Ccr5 & $\begin{array}{l}\text { Quimiocina } \\
\text { (motivo C-C) } \\
\text { receptor } 5\end{array}$ & NM_009917 & 3,04 & - & - & - \\
\hline$C D 209 a$ & Antígeno CD209a & NM_133238 & - & - & 2,49 & - \\
\hline CD36 & Antígeno CD36 & NM_007643 & - & - & 2,05 & - \\
\hline Clec4n & $\begin{array}{c}\text { Lectina tipo } \mathrm{C} \text {, } \\
\text { família } 4 \text {, membro } \\
\mathrm{n}\end{array}$ & NM_020001 & 2,31 & - & 2,75 & - \\
\hline Clec $7 a$ & $\begin{array}{c}\text { Lectina tipo C, } \\
\text { família } 7, \text { membro } \\
\text { a }\end{array}$ & NM_020008 & 13,41 & - & 2,39 & - \\
\hline Colec12 & Colectina 12 & NM_130449 & - & $\begin{array}{c}61,8 \\
2\end{array}$ & - & - \\
\hline$C s f 2$ & $\begin{array}{c}\text { Fator estimulador } \\
\text { de colônias } 2 \\
\text { (granulócito- } \\
\text { macrófago }\end{array}$ & NM_009969 & 3,9 & - & 5,2 & - \\
\hline Cxcl1 & $\begin{array}{c}\text { Quimiocina } \\
\text { (motivo C-X-C) } \\
\text { ligante } 1\end{array}$ & NM_008176 & 2,54 & - & - & - \\
\hline Cxcl10 & $\begin{array}{c}\text { Quimiocina } \\
\text { (motivo C-X-C) } \\
\text { ligante } 10\end{array}$ & NM_021274 & 49,69 & - & 2,08 & - \\
\hline Cxcl9 & $\begin{array}{c}\text { Quimiocina } \\
\text { (motivo C-X-C) } \\
\text { ligante } 9\end{array}$ & NM_008599 & 2,88 & - & - & - \\
\hline Fcgr1 & $\begin{array}{l}\text { Receptor } \mathrm{Fc}, \mathrm{IgG}, \\
\text { alta afinidade I }\end{array}$ & NM_010186 & 4,55 & - & - & - \\
\hline Fcgr3 & $\begin{array}{l}\text { Receptor Fc, IgG, } \\
\text { baixa afinidade III }\end{array}$ & NM_010188 & 3 & - & - & - \\
\hline Fcgr4 & $\begin{array}{l}\text { Receptor Fc, IgG, } \\
\text { baixa afinidade IV }\end{array}$ & NM_144559 & 20,75 & - & - & - \\
\hline Fcnb & Ficolina B & NM_010190 & - & 2,04 & - & - \\
\hline Fos & $\begin{array}{c}\text { Oncogene de } \\
\text { osteossarcoma FBJ }\end{array}$ & NM_010234 & - & - & - & 3,03 \\
\hline$I F N-y$ & Interferon gama & NM_008337 & 2,24 & - & - & - \\
\hline$I L-12 B$ & Interleucina 12B & NM_001303244 & - & - & 3,18 & - \\
\hline$I L-1 \alpha$ & Interleucina 1 alfa & NM_010554 & 6,26 & - & - & - \\
\hline
\end{tabular}




\begin{tabular}{|c|c|c|c|c|c|c|}
\hline$I L-1 \beta$ & Interleucina 1 beta & NM_008361 & 6,08 & - & 2,07 & - \\
\hline$I L-2$ & Interleucina 2 & NM_008366 & - & - & 2,6 & - \\
\hline$I L-23 A$ & Interleucina 23 & NM_031252 & - & - & - & 4,06 \\
\hline$I L-6$ & Interleucina 6 & NM_001314054 & 4,94 & - & - & - \\
\hline$M b l 2$ & $\begin{array}{l}\text { Lectina de ligação a } \\
\text { manose (proteína } \\
\text { C) } 2\end{array}$ & NM_010776 & - & - & 2,94 & 4,2 \\
\hline Mrc1 & $\begin{array}{c}\text { Receptor de } \\
\text { manose, C, tipo } 1\end{array}$ & NM_008625 & 2,78 & - & - & - \\
\hline Ptx 3 & Pentraxina & NM_008987 & 19,49 & - & 3,09 & - \\
\hline Pycard & $\begin{array}{c}\text { Domínios PYD e } \\
\text { CARD }\end{array}$ & NM_023258 & 2,49 & - & - & - \\
\hline Scarf1 & $\begin{array}{c}\text { Receptor } \\
\text { scavenger, classe F, } \\
\text { membro } 1\end{array}$ & NM_001004157 & - & 3,07 & - & - \\
\hline Sftpd & $\begin{array}{l}\text { Proteína D } \\
\text { associada a } \\
\text { surfactante }\end{array}$ & NM_009160 & - & - & 4,11 & 3,05 \\
\hline Socs 3 & $\begin{array}{c}\text { Supressor da } \\
\text { sinalização de } \\
\text { citocina } 3\end{array}$ & NM_007707 & 5,37 & - & - & - \\
\hline Syk & $\begin{array}{l}\text { Tirosina quinase do } \\
\text { baço }\end{array}$ & NM_011518 & 2,24 & - & - & - \\
\hline$T L R 4$ & Receptor toll-like 4 & NM_021297 & 2,52 & - & - & - \\
\hline TLR9 & Receptor toll-like 9 & NM_031178 & 3,33 & - & - & - \\
\hline
\end{tabular}

4.4.2. Modulação negativa da expressão gênica no pulmão, baço e cérebro de animais WT e Gal-3 KO na presença e ausência da infecção por $C$. neoformans

No pulmão, foi possível observar que 47 dos 84 genes analisados apresentaram diminuição da expressão gênica (Tabela 4). Desses 47 genes, 21 (C5ar1, CD207, CD40, Colec12, Csf2, F2r11, Ikbkb, IL-12A, IL-18, IL1r1, Irak1, Jun, Lyn, Map2k4, Mapk14, Nptx1, Raf1, Scarf1, St3gal5, Syk e Traf6) foram significativamente modulados no pulmão dos animais WT e Gal-3 KO, ambos infectados, quando comparado aos respectivos grupos controles. Além disso, verificamos modulação negativa para a expressão de Bcl10, Ccl20, Map3k7, MyD88 e Socs3 no animal WT infectado, enquanto que na ausência de Gal-3 diminuiu-se a expressão de Card9, Cc15, CD209a, Cd36, Fos, Mb12, Nfkb1, Ptgs2, Tirap e TLR2 (Figura 4A e 4B).

Quando comparamos os animais Gal-3 KO com os animais WT, observamos que, tanto na ausência como na presença da infecção, há diminuição da expressão de quatro genes em comum: Ccl20, IL-12A e IL-12B e Syk. Entretanto, houve também diminuição de transcritos 
envolvidos no sistema complemento, citocinas pro-inflamatórias, quimiocinas e seus receptores, receptor Fc e PRRs, proteínas adaptadoras e efetoras da via de transdução de sinal de PRRs e fatores de transcrição (Figura 4C e 4D).

Em relação ao baço, 48 genes apresentaram modulação negativa (Tabela 5), sendo que somente a infecção fúngica no animal WT promoveu reduzida expressão de 39 genes, comparado ao respectivo grupo controle (WT PBS) (Figura 4E). Desses 39 genes, cinco (CD207, CD209a, Csf2, MyD88 e Ptgs2) também tiveram menor expressão no animal Gal-3 KO infectado, além da diminuição de IL-2 (Figura 4F). Ao compararmos a presença ou ausência de Gal-3 nos animais, com ou sem infecção, observamos que na ausência desta, 33 genes apresentam-se regulados negativamente (Figura 4G). Já na presença da infecção, houve comum diminuição da expressão de Fcgr4, IL-12B, IL-1 $\beta$ e MyD88, além da modulação negativa de Fcgr1 (Figura 4H).

A análise da expressão no cérebro, permitiu inferir que há maior número de genes com expressão diminuída nos animais WT infectados do que nos animais Gal-3 KO infectados, quando comparados aos respectivos grupos controles. Dos 84 genes analisados, 53 apresentaram alterações significativas (Tabela 6). O gene codificador da pentraxina 1 neuronal (Nptx1) apresentou-se significativamente modulado no animal WT e Gal-3 KO comparado aos seus controles. Além desse gene, outros 13 apresentaram baixa expressão no animal WT, enquanto que apenas o receptor de reconhecimento padrão CD209a foi relatado no animal Gal3 KO (Figura 4I e 4J). Por sua vez, a ausência de Gal-3 na condição controle e na presença de infecção, promoveu diminuição da expressão de quatro e 40 genes quando comparado ao grupo WT controle e infectado, respectivamente (Figura 4K e 4L).

De forma geral, durante a infecção por C. neoformans, foi verificado que, nos animais WT e Gal- 3 KO, 46 e 79 genes apresentaram-se modulados de forma positiva e negativa, respectivamente. (Figura 5A e 5B). Os três órgãos apresentaram aumento da expressão de Mcr1 e diminuição da expressão de 15 genes (Socs3, Fos, Jun, Nptx1, Ptgs2, CD209a, Colec12, Cxcl10, Csf2, Fcgr1, Card9, Il1r1, MyD88, Ikbkb e IL-1ß). O pulmão comparado com o baço teve aumento da expressão de Chia1 e diminuição da expressão de 15 genes (CD36, Scarf1, Nfkbia, Map2k4, Mapk14, Mb12, CD207, F2r11, Map3k7, Cxcl3, Ccl20, Bcl10, C3, IL-12B, CD5), já em comparação com o cérebro, 13 (Cxcl1, Cxc19, Cxc110, Ccr1, Ccr5, Fcgr1, Fcgr3, IL-1 $\alpha$, IL-1 $\beta$, IL-6, IFN-y, Clec7a, Mb12) e 11 (Nfkb1, Traf6, Syk, Raf1, IL-12A, C5ar1, Irak1, Ccr5, Ccl5, IL-6, TLR2) genes apresentaram modulação positiva e negativa, respectivamente. Por sua vez, baço e cérebro compartilharam alta expressão de 4 genes (Scarf1, TLR9, Sftpd, 
Fcnb) e baixa expressão de 13 genes (IL-23A, IL-1ß, Cxc11, Cxc19 CD14, Ptx3, Ptpn6, Fcgr4, Malt1, Chia1, Itgam, Irak4, Cleac7a).

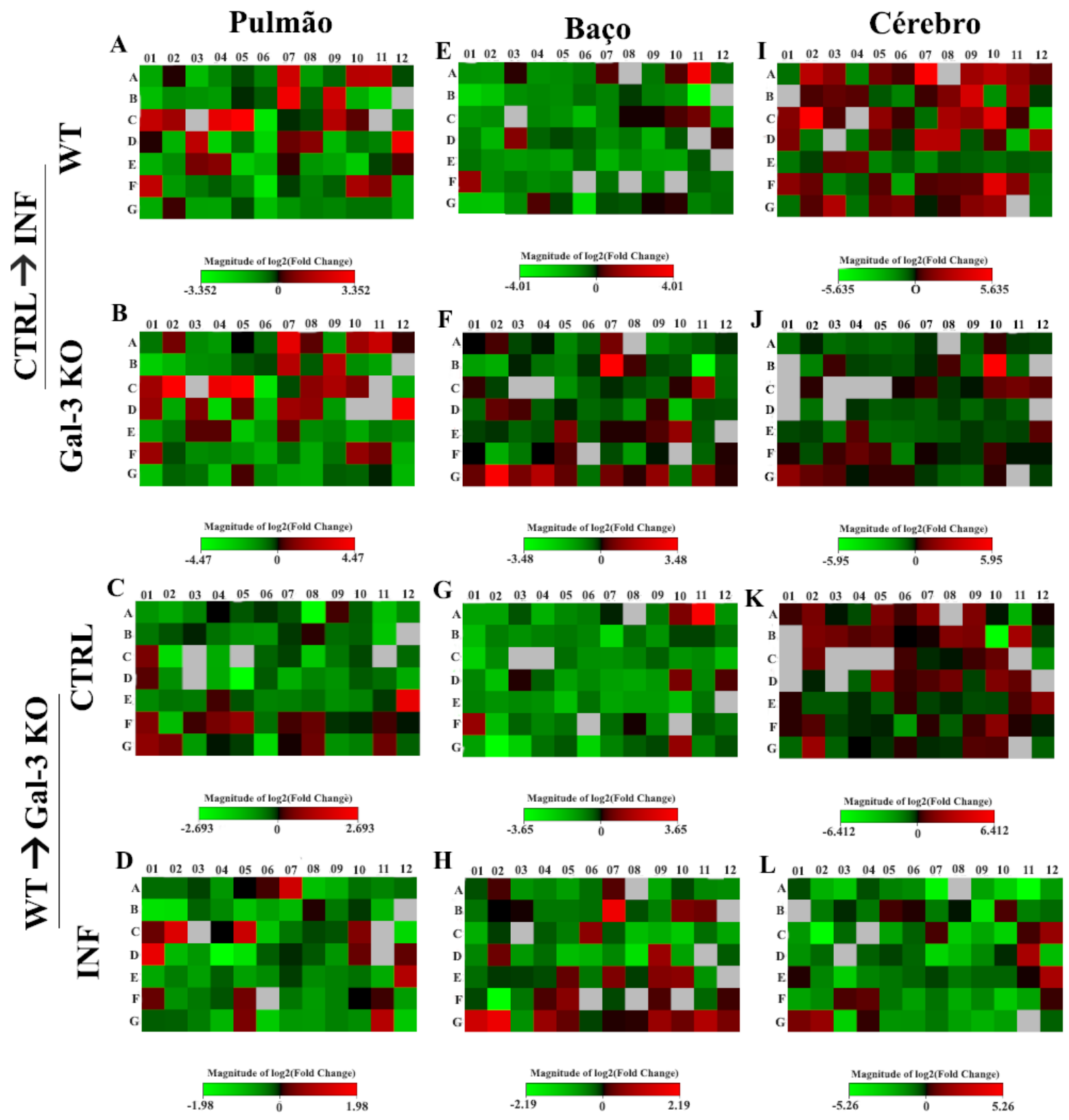

Figura 4. Heat map da expressão de genes da imunidade inata antifúngica no pulmão, baço e cérebro de camundongos WT e Gal-3 KO na ausência e presença da infecção por $C$. neoformans. As análises foram baseadas nas seguintes comparações: WT infectado comparado ao grupo WT controle (A, E, I); Gal-3 KO comparado ao Gal-3 KO controle (B, F, J); Gal-3 KO comparado ao WT, na ausência de infecção $(C, G, K)$ e Gal-3 KO controle comparado ao WT, após sete dias de infecção por C. neoformans (D, H, L). Todos os animais controles receberam solução salina tamponada de fosfato (PBS) via intratraqueal. A escala representa 
fold change, com threshold igual a 2 (vermelho: up regulados; verde: down regulados; preto: mudança média).
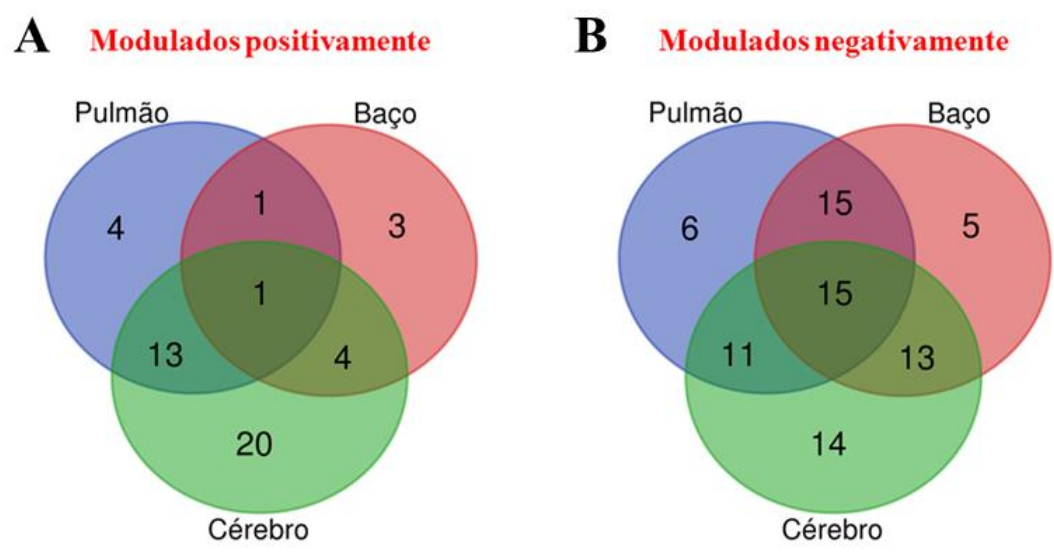

Figura 5. Diagrama de Venn da expressão de genes envolvidos na imunidade inata. Representação geral da expressão dos genes da resposta imune inata que foram modulados positivamente (A) ou negativamente (B) no pulmão, baço e cérebro de camundongos WT e Gal-3 KO na presença ou ausência da infecção por C. neoformans.

Tabela 4. Diminuição da expressão de genes envolvidos na imunidade inata no pulmão de camundongos WT e Gal-3 KO, na ausência e presença da infecção por C. neoformans.

\begin{tabular}{|c|c|c|c|c|c|c|}
\hline Gene & Descrição & RefSeq & $\begin{array}{c}\text { WT } \\
\text { CTRL/ INF }\end{array}$ & $\begin{array}{c}\text { KO } \\
\text { CTRL/ INF }\end{array}$ & $\begin{array}{c}\text { WT/ KO } \\
\text { CTRL }\end{array}$ & $\begin{array}{c}\text { WT/ KO } \\
\text { INF }\end{array}$ \\
\hline Bcl10 & $\begin{array}{l}\text { Leucemia/ } \\
\text { linfoma de } \\
\text { células B10 }\end{array}$ & NM_009740 & $-2,42$ & - & - & - \\
\hline C3 & $\begin{array}{l}\text { Complemento } \\
\text { componente } 3\end{array}$ & NM_009778 & & - & $-2,06$ & - \\
\hline C5ar1 & $\begin{array}{c}\text { Complemento } \\
\text { componente } 5 \mathrm{~A} \text {, } \\
\text { receptor } 1\end{array}$ & NM_007577 & $-3,13$ & $-2,25$ & - & - \\
\hline Card9 & $\begin{array}{l}\text { Família de } \\
\text { domínio de } \\
\text { recrutamento } \\
\text { caspase } 9\end{array}$ & $\begin{array}{c}\text { NM_001037 } \\
747\end{array}$ & - & $-2,71$ & - & - \\
\hline Ccl20 & $\begin{array}{c}\text { Quimiocina } \\
\text { (motivo C-C) } \\
\text { ligante } 20\end{array}$ & NM_016960 & $-2,16$ & - & $-6,2$ & $-2,07$ \\
\hline Ccl5 & $\begin{array}{c}\text { Quimiocina } \\
\text { (motivo C-C) } \\
\text { ligante } 5\end{array}$ & NM_013653 & & $-2,73$ & & - \\
\hline
\end{tabular}




\begin{tabular}{|c|c|c|c|c|c|c|}
\hline Ccr5 & $\begin{array}{l}\text { Quimiocina } \\
\text { (motivo C-C) } \\
\text { receptor } 5\end{array}$ & NM_009917 & - & - & $-2,68$ & - \\
\hline CD207 & Antígeno 207 & NM_144943 & $-3,29$ & $-6,77$ & - & $-2,85$ \\
\hline$C D 209 a$ & $\begin{array}{l}\text { Antígeno } \\
\text { CD209a }\end{array}$ & NM_133238 & - & $-4,32$ & - & $-2,77$ \\
\hline CD36 & Antígeno CD36 & NM_007643 & & $-2,33$ & & - \\
\hline$C D 40$ & Antígeno CD40 & NM_011611 & $-2,14$ & $-2,23$ & - & - \\
\hline CD5 & Antígeno CD5 & NM_007650 & - & - & - & $-2,1$ \\
\hline Colec12 & $\begin{array}{l}\text { Subfamília } \\
\text { collectin } 12\end{array}$ & NM_130449 & $-2,69$ & $-2,3$ & - & - \\
\hline$C s f 2$ & $\begin{array}{l}\text { Fator } \\
\text { estimulador de } \\
\text { colônias } 2 \\
\text { (granulócito- } \\
\text { macrófago }\end{array}$ & NM_009969 & $-4,78$ & $-3,16$ & $-2,83$ & - \\
\hline Cxcl10 & $\begin{array}{c}\text { Quimiocina } \\
\text { (motivo C-X-C) } \\
\text { ligante } 10\end{array}$ & NM_021274 & - & - & $-3,71$ & - \\
\hline Cxcl3 & $\begin{array}{c}\text { Quimiocina } \\
\text { (motivo C-X-C) } \\
\text { ligante } 3\end{array}$ & NM_203320 & - & - & $-2,15$ & - \\
\hline F2rl1 & $\begin{array}{l}\text { Fator de } \\
\text { coagulação II ( } \\
\text { trombina) tipo } \\
\text { receptor } 1\end{array}$ & NM_007974 & $-6,36$ & $-10,85$ & & $-2,13$ \\
\hline Fcgr1 & $\begin{array}{l}\text { Receptor Fc, } \\
\text { IgG, alta } \\
\text { afinidade I }\end{array}$ & NM_010186 & - & - & $-2,91$ & - \\
\hline Fos & $\begin{array}{c}\text { Oncogene de } \\
\text { osteossarcoma } \\
\text { FBJ }\end{array}$ & NM_010234 & - & $-3,58$ & - & $-2,57$ \\
\hline$I k b k b$ & $\begin{array}{c}\text { Inibidor de } \\
\text { Kappa B } \\
\text { quinase } \beta\end{array}$ & NM_010546 & $-2,82$ & $-3,39$ & & \\
\hline$I L-12 A$ & Interleucina $12 \mathrm{~A}$ & NM_008351 & $-4,34$ & $-8,22$ & $-2,12$ & $-3,94$ \\
\hline$I L-12 B$ & Interleucina 12B & $\begin{array}{c}\text { NM_001303 } \\
244\end{array}$ & - & - & $-6,46$ & $-2,85$ \\
\hline$I L-18$ & Interleucina 18 & NM_008360 & $-4,72$ & $-4,56$ & - & - \\
\hline$I L-1 \alpha$ & $\begin{array}{c}\text { Interleucina } 1 \\
\text { alfa }\end{array}$ & NM_010554 & - & - & $-2,19$ & - \\
\hline Il1r1 & $\begin{array}{c}\text { Receptor } \\
\text { interleucina } 1 \text {, } \\
\text { tipo I }\end{array}$ & NM_008362 & $-3,03$ & $-2,71$ & - & - \\
\hline$I L-6$ & Interleucina 6 & $\underset{054}{\text { NM_001314 }}$ & - & - & $-2,15$ & - \\
\hline
\end{tabular}




\begin{tabular}{|c|c|c|c|c|c|c|}
\hline Irak1 & $\begin{array}{c}\text { Receptor } \\
\text { interleucina } 1 \\
\text { associadoa } \\
\text { quinase } 1\end{array}$ & NM_008363 & $-2,73$ & $-2,99$ & - & - \\
\hline Jun & Oncogene Jun & NM_010591 & $-4,08$ & $-5,74$ & - & - \\
\hline Lyn & $\begin{array}{c}\text { Oncogene } \\
\text { sarcoma viral }\end{array}$ & NM_010747 & $-2,84$ & $-2,69$ & - & - \\
\hline Map2k4 & $\begin{array}{c}\text { Proteina quinase } \\
\text { quinase } 4 \\
\text { ativada por } \\
\text { mitógeno }\end{array}$ & NM_009157 & $-2,05$ & $-2,2$ & - & - \\
\hline Map3k7 & $\begin{array}{l}\text { Proteina quinase } \\
\text { quinase quinase } \\
4 \text { ativada por } \\
\text { mitógeno }\end{array}$ & NM_172688 & $-2,37$ & - & - & - \\
\hline Mapk14 & $\begin{array}{l}\text { Proteina quinase } \\
14 \text { ativada por } \\
\text { mitógeno }\end{array}$ & N M_011951 & $-3,99$ & $-3,41$ & - & - \\
\hline$M b l 2$ & $\begin{array}{l}\text { Lectina de } \\
\text { ligação a } \\
\text { manose } \\
\text { (proteína C) } 2\end{array}$ & NM_010776 & - & $-2,11$ & - & - \\
\hline MyD88 & $\begin{array}{c}\text { Gene de } \\
\text { resposta } \\
\text { primária de } \\
\text { diferenciação } \\
\text { mielóide } 88\end{array}$ & NM_010851 & $-2,11$ & - & $-2,52$ & - \\
\hline Nfkb1 & $\begin{array}{l}\text { Fator nuclear do } \\
\text { potenciador do } \\
\text { gene do } \\
\text { polipeptídeo } \\
\text { kappa nas } \\
\text { células B1 }\end{array}$ & NM_008689 & - & $-2,22$ & - & - \\
\hline Nfkbia & $\begin{array}{l}\text { Inibidor do fator } \\
\text { nuclear do } \\
\text { potenciador do } \\
\text { gene do } \\
\text { polipeptídeo } \\
\text { kappa nas } \\
\text { células B1 }\end{array}$ & NM_010907 & - & $-2,08$ & - & - \\
\hline Nlrp3 & Família NLR & NM_145827 & - & $-2,48$ & - & - \\
\hline Nptx1 & $\begin{array}{l}\text { Pentraxina } \\
\text { neuronal } 1\end{array}$ & NM_008730 & $-6,22$ & $-3,71$ & - & $\begin{array}{ll}- & - \\
\end{array}$ \\
\hline Ptgs 2 & $\begin{array}{l}\text { Prostaglandina- } \\
\text { endoperóxido } \\
\text { sintase } 2\end{array}$ & NM_011198 & - & $-3,39$ & - & 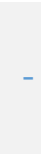 \\
\hline
\end{tabular}




\begin{tabular}{|c|c|c|c|c|c|c|}
\hline Raf1 & $\begin{array}{l}\text { Oncogene viral } \\
\text { V-raf-leucemia } \\
1\end{array}$ & NM_029780 & $-2,34$ & $-3,76$ & - & - \\
\hline Scarf1 & $\begin{array}{l}\text { Receptor } \\
\text { scavenger, } \\
\text { classe F, } \\
\text { membro } 1\end{array}$ & $\begin{array}{c}\text { NM_001004 } \\
157\end{array}$ & $-2,6$ & $-5,13$ & - & - \\
\hline Socs3 & $\begin{array}{c}\text { Supressor da } \\
\text { sinalização de } \\
\text { citocina } 3\end{array}$ & NM_007707 & $-2,29$ & - & & - \\
\hline St3gal5 & $\begin{array}{c}\text { ST3- beta- } \\
\text { galactoside alfa- } \\
2,3- \\
\text { sialiltransferase } \\
5\end{array}$ & NM_011375 & $-2,37$ & $-4,5$ & - & - \\
\hline Syk & $\begin{array}{l}\text { Tirosina quinase } \\
\text { do baço }\end{array}$ & NM_011518 & $-3,29$ & $-2,11$ & $-3,61$ & $-2,28$ \\
\hline Tirap & $\begin{array}{l}\text { Receptor Toll- } \\
\text { interleucina } 1 \\
\text { (TIR) }\end{array}$ & NM_054096 & - & $-3,16$ & - & - \\
\hline TLR2 & $\begin{array}{l}\text { Receptor toll- } \\
\quad \text { like } 2\end{array}$ & NM_011905 & - & $-3,36$ & & - \\
\hline Traf6 & $\begin{array}{c}\text { Tnf receptor } \\
\text { associado a fator } \\
6\end{array}$ & NM_009424 & $-2,34$ & $-4,26$ & & $-2,22$ \\
\hline
\end{tabular}

Tabela 5. Diminuição da expressão de genes envolvidos na imunidade inata no baço de camundongos WT e Gal-3 KO, na ausência e presença da infecção por C. neoformans.

\begin{tabular}{|c|c|c|c|c|c|c|}
\hline Gene & Descrição & RefSeq & $\begin{array}{c}\text { WT } \\
\text { CTRL/ INF }\end{array}$ & $\begin{array}{c}\text { KO } \\
\text { CTRL/ INF }\end{array}$ & $\begin{array}{c}\text { WT/ KO } \\
\text { CTRL }\end{array}$ & $\begin{array}{c}\text { WT/ KO } \\
\text { INF }\end{array}$ \\
\hline Bcl10 & $\begin{array}{l}\text { Leucemia/ } \\
\text { linfoma de } \\
\text { células B10 }\end{array}$ & NM_009740 & $-2,28$ & - & $-2,55$ & - \\
\hline $\mathrm{C3}$ & $\begin{array}{l}\text { Complemento } \\
\text { componente } 3\end{array}$ & NM_009778 & $-2,41$ & - & $-2,53$ & - \\
\hline Card9 & $\begin{array}{l}\text { Família de } \\
\text { domínio de } \\
\text { recrutamento } \\
\text { caspase } 9\end{array}$ & NM_0010377 & $-2,2$ & - & $-3,01$ & - \\
\hline Ccl20 & $\begin{array}{c}\text { Quimiocina } \\
\text { (motivo C-C) } \\
\text { ligante } 20\end{array}$ & NM_016960 & $-2,1$ & - & $-2,35$ & - \\
\hline
\end{tabular}




\begin{tabular}{|c|c|c|c|c|c|c|}
\hline CD14 & $\begin{array}{c}\text { Antígeno } \\
\text { CD14 }\end{array}$ & NM_009841 & - & - & $-2,1$ & - \\
\hline CD207 & $\begin{array}{l}\text { Antígeno } \\
\text { CD207 }\end{array}$ & NM_144943 & $-6,19$ & $-2,28$ & $-3,46$ & - \\
\hline$C D 209 a$ & $\begin{array}{l}\text { Antígeno } \\
\text { CD209a }\end{array}$ & NM_133238 & $-4,72$ & $-2,75$ & - & - \\
\hline CD36 & $\begin{array}{c}\text { Antígeno } \\
\text { CD36 }\end{array}$ & NM_007643 & $-2,16$ & - & $-2,03$ & - \\
\hline CD5 & Antígeno CD5 & NM_007650 & $-2,08$ & - & - & - \\
\hline Chial & Quitinase & NM_023186 & - & - & $-5,5$ & - \\
\hline Clec7a & $\begin{array}{l}\text { Lectina tipo C, } \\
\text { família } 7, \\
\text { membro a }\end{array}$ & NM_020008 & - & - & $-2,07$ & - \\
\hline Colec 12 & $\begin{array}{l}\text { Subfamília } \\
\text { collectin } 12\end{array}$ & NM_130449 & $-2,03$ & - & - & - \\
\hline $\operatorname{Csf} 2$ & $\begin{array}{c}\text { Fator } \\
\text { estimulador de } \\
\text { colônias } 2 \\
\text { (granulócito- } \\
\text { macrófago }\end{array}$ & NM_009969 & $-16,11$ & $-10,85$ & - & - \\
\hline $\operatorname{Csf} 3$ & $\begin{array}{c}\text { Fator } \\
\text { estimulador de } \\
\text { colônias } 3 \\
\text { (granulócito- } \\
\text { macrófago }\end{array}$ & NM_009971 & $-2,1$ & - & - & - \\
\hline Cxcl1 & $\begin{array}{l}\text { Quimiocina } \\
\text { (motivo C-X- } \\
\text { C) ligante } 1\end{array}$ & NM_008176 & $-2,33$ & & $-4,69$ & - \\
\hline Cxcl10 & $\begin{array}{l}\text { Quimiocina } \\
\text { (motivo C-X- } \\
\text { C) ligante } 10\end{array}$ & NM_021274 & $-2,1$ & - & - & - \\
\hline Cxcl11 & $\begin{array}{l}\text { Quimiocina } \\
\text { (motivo C-X- } \\
\text { C) ligante } 11\end{array}$ & NM_019494 & $-2,1$ & - & $-2,35$ & - \\
\hline Cxcl3 & $\begin{array}{l}\text { Quimiocina } \\
\text { (motivo C-X- } \\
\text { C) ligante } 3\end{array}$ & NM_203320 & - & - & $-2,35$ & - \\
\hline Cxcl9 & $\begin{array}{l}\text { Quimiocina } \\
\text { (motivo C-X- } \\
\text { C) ligante } 9\end{array}$ & NM_008599 & $-2,2$ & - & - & - \\
\hline F2rl1 & $\begin{array}{c}\text { Fator de } \\
\text { coagulação II } \\
\text { (trombina) tipo } \\
\text { receptor } 1\end{array}$ & NM_007974 & $-3,94$ & - & - & - \\
\hline Fcgr1 & $\begin{array}{l}\text { Receptor Fc, } \\
\text { IgG, alta } \\
\text { afinidade I }\end{array}$ & NM_010186 & - & - & - & $-2,17$ \\
\hline
\end{tabular}




\begin{tabular}{|c|c|c|c|c|c|c|}
\hline Fcgr4 & $\begin{array}{l}\text { Receptor Fc, } \\
\text { IgG, baixa } \\
\text { afinidade IV }\end{array}$ & NM_144559 & - & - & $-2,08$ & $-2,45$ \\
\hline FOS & $\begin{array}{c}\text { Oncogene de } \\
\text { osteossarcoma } \\
\text { FBJ }\end{array}$ & NM_010234 & $-2,77$ & - & $-3,43$ & - \\
\hline Ikbkb & $\begin{array}{c}\text { Inibidor de } \\
\text { Kappa B } \\
\text { quinase } \beta\end{array}$ & NM_010546 & $-3,63$ & - & $-3,86$ & - \\
\hline$I L-12 B$ & $\begin{array}{c}\text { Interleucina } \\
12 \mathrm{~B}\end{array}$ & $\begin{array}{c}\text { NM_0013032 } \\
44\end{array}$ & - & - & $-2,43$ & $-2,16$ \\
\hline$I L-1 \alpha$ & $\begin{array}{c}\text { Interleucina } 1 \\
\text { alfa }\end{array}$ & NM_010554 & $-2,13$ & - & $-2,43$ & - \\
\hline$I L-1 \beta$ & $\begin{array}{c}\text { Interleucina } 1 \\
\text { beta }\end{array}$ & NM_008361 & - & - & $-2,64$ & $-3,14$ \\
\hline Illr1 & $\begin{array}{c}\text { Receptor } \\
\text { interleucina } 1, \\
\text { tipo I }\end{array}$ & NM_008362 & $-3,32$ & - & $-2,2$ & - \\
\hline$I L-2$ & Interleucina 2 & NM_008366 & - & $-3,58$ & - & - \\
\hline$I L-23 A$ & $\begin{array}{c}\text { Interleucina } \\
23 \mathrm{~A}\end{array}$ & NM_031252 & $-2,1$ & - & - & - \\
\hline Irak4 & $\begin{array}{c}\text { Receptor } \\
\text { interleucina } 1 \\
\text { associadoa } \\
\text { quinase } 4\end{array}$ & NM_029926 & $-2,16$ & - & $-2,08$ & - \\
\hline Itgam & $\begin{array}{c}\text { Integrina alfa } \\
\text { M }\end{array}$ & NM_008401 & $-2,43$ & - & - & - \\
\hline Jun & Oncogene Jun & NM_010591 & $-2,68$ & - & $-3,61$ & - \\
\hline Malt1 & $\begin{array}{c}\text { Mucosa } \\
\text { associado gene } \\
\text { de } \\
\text { translocação } \\
\text { do linfoma do } \\
\text { tecido linfoide } \\
1\end{array}$ & NM_172833 & $-3,46$ & - & $-2,6$ & - \\
\hline $\operatorname{Map} 2 k 4$ & $\begin{array}{l}\text { Proteina } \\
\text { quinase } \\
\text { quinase } 4 \\
\text { ativada por } \\
\text { mitógeno }\end{array}$ & NM_009157 & $-2,04$ & - & $-2,25$ & - \\
\hline Map3k7 & $\begin{array}{l}\text { Proteina } \\
\text { quinase } \\
\text { quinase } \\
\text { quinase } 4 \\
\text { ativada por } \\
\text { mitógeno }\end{array}$ & NM_172688 & $-2,69$ & - & $-2,27$ & - \\
\hline Mapk14 & $\begin{array}{c}\text { Proteina } \\
\text { quinase } 14\end{array}$ & N M_011951 & $-2,71$ & - & $-3,63$ & - \\
\hline
\end{tabular}




\begin{tabular}{|c|c|c|c|c|c|c|}
\hline & $\begin{array}{l}\text { ativada por } \\
\text { mitógeno }\end{array}$ & & & & & \\
\hline Mbl2 & $\begin{array}{l}\text { Lectina de } \\
\text { ligação a } \\
\text { manose } \\
\text { (proteína C) } 2\end{array}$ & NM_010776 & $-2,1$ & - & $-2,35$ & - \\
\hline MyD88 & $\begin{array}{c}\text { Gene de } \\
\text { resposta } \\
\text { primária de } \\
\text { diferenciação } \\
\text { mielóide } 88\end{array}$ & NM_010851 & $-2,11$ & $-2,73$ & $-3,48$ & $-4,56$ \\
\hline Nfkbia & $\begin{array}{l}\text { Inibidor do } \\
\text { fator nuclear } \\
\text { do potenciador } \\
\text { do gene do } \\
\text { polipeptídeo } \\
\text { kappa nas } \\
\text { células B1 }\end{array}$ & NM_010907 & $-2,06$ & - & - & - \\
\hline Nptx1 & $\begin{array}{l}\text { Pentraxina } \\
\text { neuronal } 1\end{array}$ & NM_008730 & $-2,1$ & - & $-2,35$ & - \\
\hline Ptgs 2 & $\begin{array}{l}\text { Prostaglandina } \\
\text { - endoperóxido } \\
\text { sintase } 2\end{array}$ & NM_011198 & $-2,1$ & $-2,23$ & - & - \\
\hline Ptpn6 & $\begin{array}{l}\text { Proteína } \\
\text { Tirosina } \\
\text { fosfatase não } \\
\text { receptor } 6\end{array}$ & NM_013545 & $-2,07$ & - & - & - \\
\hline Ptx 3 & Pentraxina 3 & NM_008987 & $-2,1$ & & $-2,35$ & \\
\hline Scarf1 & $\begin{array}{l}\text { Receptor } \\
\text { scavenger, } \\
\text { classe F, } \\
\text { membro } 1\end{array}$ & $\begin{array}{c}\text { NM_0010041 } \\
57\end{array}$ & $-4,53$ & - & $-2,43$ & - \\
\hline Sftpf & $\begin{array}{l}\text { Proteína D } \\
\text { associada a } \\
\text { surfactante }\end{array}$ & NM_009160 & $-4,66$ & - & $-12,55$ & - \\
\hline Socs3 & $\begin{array}{c}\text { Supressor da } \\
\text { sinalização de } \\
\text { citocina } 3\end{array}$ & NM_007707 & $-2,07$ & - & $-4,92$ & - \\
\hline Syk & $\begin{array}{l}\text { Tirosina } \\
\text { quinase do } \\
\text { baço }\end{array}$ & NM_011518 & $-7,26$ & - & $-5,28$ & - \\
\hline
\end{tabular}


Tabela 6. Diminuição da expressão de genes envolvidos na imunidade inata no cérebro de camundongos WT e Gal-3 KO, na ausência e presença da infecção por C. neoformans.

\begin{tabular}{|c|c|c|c|c|c|c|}
\hline Gene & Descrição & RefSeq & $\begin{array}{c}\text { WT } \\
\text { CTRL/ INF }\end{array}$ & $\begin{array}{c}\text { KO } \\
\text { CTRL/ INF }\end{array}$ & $\begin{array}{c}\text { WT/ KO } \\
\text { CTRL }\end{array}$ & $\begin{array}{c}\text { WT/ KO } \\
\text { INF }\end{array}$ \\
\hline$C 3$ & $\begin{array}{l}\text { Complemento } \\
\text { componente } 3\end{array}$ & $\begin{array}{c}\text { NM_0097 } \\
78\end{array}$ & - & - & - & $-4,86$ \\
\hline C5ar1 & $\begin{array}{l}\text { Complemento } \\
\text { componente } \\
5 \mathrm{~A}, \text { receptor } 1\end{array}$ & $\begin{array}{c}\text { NM_0075 } \\
77\end{array}$ & - & - & - & $-7,89$ \\
\hline Card9 & $\begin{array}{l}\text { Família de } \\
\text { domínio de } \\
\text { recrutamento } \\
\text { caspase } 9\end{array}$ & $\begin{array}{c}\text { NM_0010 } \\
37747\end{array}$ & $-2,59$ & - & - & - \\
\hline Casp1 & Caspase 1 & $\begin{array}{c}\text { NM_0098 } \\
07\end{array}$ & - & - & - & $-2,22$ \\
\hline Casp8 & Caspase 8 & $\begin{array}{c}\text { NM_0098 } \\
12\end{array}$ & - & - & - & $-2,57$ \\
\hline Ccl12 & $\begin{array}{c}\text { Quimiocina } \\
\text { (motivo C-C) } \\
\text { ligante } 12\end{array}$ & $\begin{array}{c}\text { NM_0113 } \\
31\end{array}$ & - & - & - & $-26,72$ \\
\hline Ccl5 & $\begin{array}{c}\text { Quimiocina } \\
\text { (motivo C-C) } \\
\text { ligante } 5\end{array}$ & $\begin{array}{c}\text { NM_0136 } \\
53\end{array}$ & - & - & - & $-3,81$ \\
\hline Ccr1 & $\begin{array}{l}\text { Quimiocina } \\
\text { (motivo C-C) } \\
\text { receptor } 1\end{array}$ & $\begin{array}{c}\text { M_00991 } \\
2\end{array}$ & - & - & - & $-9,85$ \\
\hline Ccr5 & $\begin{array}{l}\text { Quimiocina } \\
\text { (motivo C-C) } \\
\text { receptor } 5\end{array}$ & $\begin{array}{c}\text { NM_0099 } \\
17\end{array}$ & - & - & $-6,69$ & $-38,32$ \\
\hline CD14 & $\begin{array}{l}\text { Antígeno } \\
\text { CD14 }\end{array}$ & $\begin{array}{c}\text { NM_0098 } \\
41\end{array}$ & - & - & - & $-3,2$ \\
\hline$C D 209 a$ & $\begin{array}{l}\text { Antígeno } \\
\text { CD209a }\end{array}$ & $\begin{array}{c}\text { NM_1332 } \\
38\end{array}$ & - & $-2,45$ & - & $-2,07$ \\
\hline CD83 & $\begin{array}{l}\text { Antígeno } \\
\text { CD83 }\end{array}$ & $\begin{array}{c}\text { NM_0098 } \\
56\end{array}$ & $-2,44$ & - & - & - \\
\hline Chial & Quitinase & $\begin{array}{c}\text { NM_0231 } \\
86\end{array}$ & - & - & - & $-2,03$ \\
\hline Clec $7 a$ & $\begin{array}{c}\text { Lectina tipo C, } \\
\text { família } 7, \\
\text { membro a }\end{array}$ & $\begin{array}{c}\text { NM_0200 } \\
08\end{array}$ & - & - & - & $-16,68$ \\
\hline
\end{tabular}




\begin{tabular}{|c|c|c|c|c|c|c|}
\hline Colec12 & $\begin{array}{l}\text { Subfamília } \\
\text { collectin } 12\end{array}$ & $\begin{array}{c}\text { NM_1304 } \\
49\end{array}$ & $-2,88$ & - & $-85,16$ & - \\
\hline Csf2 & $\begin{array}{c}\text { Fator } \\
\text { estimulador de } \\
\text { colônias } 2 \\
\text { (granulócito- } \\
\text { macrófago }\end{array}$ & $\begin{array}{c}\text { NM_0099 } \\
69\end{array}$ & - & - & - & $-2,19$ \\
\hline Cxcl1 & $\begin{array}{l}\text { Quimiocina } \\
\text { (motivo C-X- } \\
\text { C) ligante } 1\end{array}$ & $\begin{array}{c}\text { NM_0081 } \\
76\end{array}$ & - & - & - & $-3,16$ \\
\hline Cxcl10 & $\begin{array}{l}\text { Quimiocina } \\
\text { (motivo C-X- } \\
\text { C) ligante } 10\end{array}$ & $\begin{array}{c}\text { NM_0212 } \\
74\end{array}$ & - & - & - & $-34,78$ \\
\hline Cxcl9 & $\begin{array}{l}\text { Quimiocina } \\
\text { (motivo C-X- } \\
\text { C) ligante } 9\end{array}$ & $\begin{array}{c}\text { NM_0085 } \\
99\end{array}$ & - & - & - & $-3,58$ \\
\hline Fcgr1 & $\begin{array}{l}\text { Receptor Fc, } \\
\text { IgG, alta } \\
\text { afinidade I }\end{array}$ & $\begin{array}{c}\text { NM_0101 } \\
86\end{array}$ & - & - & - & $-8,88$ \\
\hline Fcgr3 & $\begin{array}{l}\text { Receptor Fc, } \\
\text { IgG, baixa } \\
\text { afinidade III }\end{array}$ & $\begin{array}{c}\text { NM_0101 } \\
88\end{array}$ & - & - & - & $-4,08$ \\
\hline Fcgr4 & $\begin{array}{l}\text { Receptor Fc, } \\
\text { IgG, baixa } \\
\text { afinidade IV }\end{array}$ & $\begin{array}{c}\text { NM_1445 } \\
59\end{array}$ & - & - & - & $-10,78$ \\
\hline FOS & $\begin{array}{c}\text { Oncogene de } \\
\text { osteossarcoma } \\
\text { FBJ }\end{array}$ & $\begin{array}{c}\text { NM_0102 } \\
34\end{array}$ & $-11,35$ & - & $-3,51$ & - \\
\hline$I F N-Y$ & Interferon $\mathrm{y}$ & $\begin{array}{c}\text { NM_0083 } \\
37\end{array}$ & - & - & - & $-2,79$ \\
\hline Ikbkb & $\begin{array}{l}\text { Inibidor de } \\
\text { Kappa B } \\
\text { quinase } \beta\end{array}$ & $\begin{array}{c}\text { NM_0105 } \\
46\end{array}$ & $-2,02$ & - & - & - \\
\hline$I L-12 A$ & $\begin{array}{c}\text { Interleucina } \\
12 \mathrm{~A}\end{array}$ & NM_0083 & $-2,08$ & - & - & - \\
\hline$I L-1 \alpha$ & $\begin{array}{c}\text { Interleucina } 1 \\
\text { alfa }\end{array}$ & $\begin{array}{c}\text { NM_0105 } \\
54\end{array}$ & - & - & - & $-11,39$ \\
\hline$I L-1 \beta$ & $\begin{array}{c}\text { Interleucina } 1 \\
\text { beta }\end{array}$ & NM_0083 & - & - & - & $-5,74$ \\
\hline Illr1 & $\begin{array}{c}\text { Receptor } \\
\text { interleucina } 1 \text {, } \\
\text { tipo I }\end{array}$ & NM_0083 & - & - & - & $-2,51$ \\
\hline$I L-23 A$ & $\begin{array}{c}\text { Interleucina } \\
23 \mathrm{~A}\end{array}$ & $\begin{array}{c}\text { NM_0312 } \\
52\end{array}$ & $-5,96$ & - & - & - \\
\hline$I L-6$ & Interleucina 6 & $\begin{array}{c}\text { NM_0013 } \\
14054\end{array}$ & - & - & - & $-6,15$ \\
\hline Irak1 & $\begin{array}{c}\text { Receptor } \\
\text { interleucina } 1\end{array}$ & NM_0083 & $-2,03$ & - & - & - \\
\hline
\end{tabular}




\begin{tabular}{|c|c|c|c|c|c|c|}
\hline & $\begin{array}{c}\text { associadoa } \\
\text { quinase } 1\end{array}$ & & & & & \\
\hline Irak4 & $\begin{array}{c}\text { Receptor } \\
\text { interleucina } 1 \\
\text { associadoa } \\
\text { quinase } 4\end{array}$ & $\begin{array}{c}\text { NM_0299 } \\
26\end{array}$ & - & - & - & $-2,38$ \\
\hline Itgam & $\begin{array}{c}\text { Integrina alfa } \\
\mathrm{M}\end{array}$ & $\begin{array}{c}\text { NM_0084 } \\
01\end{array}$ & - & - & - & $-8,75$ \\
\hline $\operatorname{Itg} b 2$ & Integrina $\beta 2$ & $\begin{array}{c}\text { NM_0084 } \\
04\end{array}$ & - & - & - & $-2,3$ \\
\hline Jun & Oncogene Jun & $\begin{array}{c}\text { NM_0105 } \\
91\end{array}$ & $-2,4$ & - & - & - \\
\hline Malt1 & $\begin{array}{c}\text { Mucosa } \\
\text { associado gene } \\
\text { de } \\
\text { translocação } \\
\text { do linfoma do } \\
\text { tecido linfoide } \\
1\end{array}$ & $\begin{array}{c}\text { NM_1728 } \\
33\end{array}$ & $-2,63$ & - & - & - \\
\hline Mcr1 & $\begin{array}{l}\text { Receptor de } \\
\text { manose, C, } \\
\text { tipo } 1\end{array}$ & $\begin{array}{c}\text { NM_0086 } \\
25\end{array}$ & - & - & - & $-3,78$ \\
\hline MyD88 & $\begin{array}{c}\text { Gene de } \\
\text { resposta } \\
\text { primária de } \\
\text { diferenciação } \\
\text { mielóide } 88\end{array}$ & $\begin{array}{c}\text { NM_0108 } \\
51\end{array}$ & - & - & - & $-2,55$ \\
\hline Nfkbl & $\begin{array}{l}\text { Fator nuclear } \\
\text { do potenciador } \\
\text { do gene do } \\
\text { polipeptídeo } \\
\text { kappa nas } \\
\text { células B1 }\end{array}$ & $\begin{array}{c}\text { NM_0086 } \\
89\end{array}$ & $-2,2$ & - & - & - \\
\hline Nptx1 & $\begin{array}{l}\text { Pentraxina } \\
\text { neuronal } 1\end{array}$ & $\begin{array}{c}\text { NM_0087 } \\
30\end{array}$ & $-4,21$ & $-2,33$ & $-4,06$ & $-3,63$ \\
\hline Ptgs2 & $\begin{array}{l}\text { Prostaglandina } \\
\text { - endoperóxido } \\
\text { sintase } 2\end{array}$ & $\begin{array}{c}\text { NM_0111 } \\
98\end{array}$ & - & - & - & $-4,38$ \\
\hline Ptpn6 & $\begin{array}{c}\text { Proteína } \\
\text { Tirosina } \\
\text { fosfatase não } \\
\text { receptor } 6\end{array}$ & $\begin{array}{c}\text { NM_0135 } \\
45\end{array}$ & - & - & - & $-2,41$ \\
\hline Ptx3 & Pentraxina 3 & $\begin{array}{c}\text { NM_0089 } \\
87\end{array}$ & - & & - & $-8,22$ \\
\hline Pycard & $\begin{array}{l}\text { PYD e CARD } \\
\text { domínio }\end{array}$ & $\begin{array}{c}\text { NM_0232 } \\
58\end{array}$ & - & - & - & $-3,81$ \\
\hline
\end{tabular}




\begin{tabular}{|c|c|c|c|c|c|c|}
\hline Raf1 & $\begin{array}{l}\text { Oncogene } \\
\text { viral V-raf- } \\
\text { leucemia } 1\end{array}$ & $\begin{array}{c}\text { NM_0297 } \\
80\end{array}$ & $-2,11$ & - & - & - \\
\hline Socs3 & $\begin{array}{c}\text { Supressor da } \\
\text { sinalização de } \\
\text { citocina } 3\end{array}$ & $\begin{array}{c}\text { NM_0077 } \\
07\end{array}$ & - & - & - & $-10,27$ \\
\hline Stat1 & $\begin{array}{c}\text { Transdutor de } \\
\text { sinal e ativador } \\
\text { de transcrição } \\
1\end{array}$ & $\begin{array}{c}\text { NM_0092 } \\
83\end{array}$ & - & - & - & $-2,95$ \\
\hline Syk & $\begin{array}{l}\text { Tirosina } \\
\text { quinase do } \\
\text { baço }\end{array}$ & $\begin{array}{c}\text { NM_0115 } \\
18\end{array}$ & - & - & - & $-2,87$ \\
\hline$T L R 2$ & $\begin{array}{c}\text { Receptor Toll- } \\
2\end{array}$ & $\begin{array}{c}\text { NM_0119 } \\
05\end{array}$ & - & - & - & $-3,61$ \\
\hline TLR4 & $\begin{array}{c}\text { Receptor Toll- } \\
4\end{array}$ & $\begin{array}{c}\text { NM_0212 } \\
97\end{array}$ & - & - & - & $-5,03$ \\
\hline TLR9 & $\begin{array}{c}\text { Receptor Toll- } \\
9\end{array}$ & $\begin{array}{c}\text { NM_0311 } \\
78\end{array}$ & - & - & - & $-3,48$ \\
\hline Traf6 & $\begin{array}{l}\text { Tnf receptor } \\
\text { associado a } \\
\text { fator } 6\end{array}$ & $\begin{array}{c}\text { NM_0094 } \\
24\end{array}$ & $-2,14$ & - & - & - \\
\hline
\end{tabular}


5. DISCUSSÃO 


\section{DISCUSSÃO}

Neste presente estudo, tivemos como principal objetivo avaliar a influência de Gal-3 durante a infecção por C. neoformans. Primeiramente, observamos que animais Gal-3 KO apresentam menor sobrevida quando comparado aos animais selvagens (WT), fato esse que corroborou com o aumento da carga fúngica no pulmão e cérebro desses animais. Além disso, ao avaliarmos a resposta imune frente a criptococose, observamos que a deficiência de Gal-3 afeta o perfil de resposta imune Th17.

Estudos prévios avaliaram o efeito de Gal-3 na sobrevivência de camundongos à infecção por P. brasiliensis (Ruas, L. P. et al., 2009) e C. albicans (Linden et al., 2013). Em consonância com os nossos resultados, também foi verificado que tanto a infecção por $P$. brasiliensis (Ruas, L. P. et al., 2009) quanto a infecção por C. albicans (Linden et al., 2013), apresentaram menor sobrevida dos animais deficientes de Gal-3 quando comparado aos animais selvagens. Adicionalmente, a carga fúngica do pulmão e fígado infectados com $P$. brasiliensis apresentaram drástico aumento nos animais Gal-3 KO comparados com os animais WT (Ruas, L. P. et al., 2009). Resultados similares foram verificados na infecção de camundongos Gal-3 KO por C. albicans, onde a deficiência de Gal-3 também foi associada ao aumento da infecção fúngica (Linden et al., 2013). Corroborando esses resultados, nossos dados avaliando a infecção de camundongos por $C$. neoformans, também sugerem que a deficiência de Gal-3 está associada com alta vulnerabilidade a infecção fúngica, e provavelmente Gal-3 contribui para a resistência do hospedeiro contra esse patógeno.

Ruas L., et al. estudaram o balanço da resposta Th1/Th2 na infecção experimental por P. brasiliensis na ausência de Gal-3. Foi verificado que na paracoccidiodomicose (PCM), camundongos Gal-3 KO desenvolvem polarização da resposta imune para o perfil Th2, sendo um fato consistente com o aumento da susceptibilidade desses camundongos para infecções fúngicas (Ruas, L. P. et al., 2009). Por outro lado, quando avaliado a infecção por Histoplasma capsulatum, foi verificado que Gal-3 regula negativamente a resposta IL-17, apresentando menor produção de citocinas IL-23/IL-17A por células dendríticas (Wu et al., 2013).

Estes estudos suportam a hipótese de que Gal-3 desempenha papel negativo na indução da imunidade antifúngica. Por outro lado, nossos dados demonstram aumento de IL-17, IL-23, IL-12p40 e IL-6, no pulmão e baço de camundongos WT infectados com C. neoformans. Uma vez que não foi observado aumento de IFN- $\gamma$, atribuímos a detecção elevada de IL-12p40 ao aumento de IL-23, uma vez que essa citocina compartilha a subunidade p40 da IL-12. Além disso, estudos realizados em modelos experimentais de candidíase, mostram a participação de 
Gal-3 na geração de resposta imune protetora Th17 contra candidíase (Jouault et al., 2006; Hernández-Santos et al., 2013; Linden et al., 2013), corroborando os resultados encontrados neste estudo para C. neoformans.

Analisando de forma geral os dados obtidos através do PCR Array no pulmão, baço e cérebro de camundongos WT e Gal-3 KO, na ausência e presença da infecção por $C$. neoformans, foi possível observar aumento significativo na expressão de transcritos relacionados aos PRRs, principalmente o receptor de manose (Mrc1). Além disso, houve modulação positiva para receptor Toll associado à resposta antifúngica (TLR9), receptor lectina tipo C como Dectina-1 (Clec7a) e receptor scavenger (Scarf1). Além desses receptores, detectou-se aumento na expressão de moléculas de reconhecimento de padrões solúveis como pentraxinas, colectinas e ficolinas. Ademais, também houve aumento na modulação de genes para citocinas pró-inflamatórias (IL-6, IFN-y, IL-1 $\alpha$ e IL-1 $\beta$ ) e de quimiocinas e seus receptores (Ccl12, Cxcl1, Cxc19, Cxcl10, Ccr1 e Ccr5).

Células imunes do hospedeiro podem promover a fagocitose de patógenos através da interação PRRs- PAMPs (Brubaker et al., 2015; Walsh et al., 2017). Os receptores de lectina tipo C (CLRs) - uma das classes de PRRs já caracterizadas - são fundamentais para o reconhecimento fúngico e início da resposta imune inata e adaptativa (Goyal et al., 2018). Dectina-1, um dos mais estudados CLRs, é responsável pelo reconhecimento de $\beta$-1,3-glucano (Goyal et al., 2018) presentes em diversas espécies de fungos, incluindo, Candida sp.(Kashem et al., 2015), Coccidioides sp. (Viriyakosol et al., 2005), Pneumocystis sp. (Steele et al., 2003) e Aspergillus sp. (Gersuk et al., 2006).

A modulação positiva do gene de Dectina-1 no pulmão e cérebro de camundongos WT e Gal-3 KO infectados com C. neoformans, corrobora com estudos in vitro que demonstram a função desse receptor em uma variedade de respostas celulares antifúngicas, incluindo fagocitose e produção de citocinas e quimiocinas. (Taylor et al., 2007). Além disso, Taylor e colaboradores mostraram que camundongos com ausência de Dectina-1 apresentam ativação defeituosa de macrófagos residentes, com deficiente recrutamento de células mielóides, e subsequente impedimento da resposta inflamatória. Portanto, a ausência de Dectina-1 e de resposta inflamatória, resultou em maior disseminação do patógeno e suscetibilidade do hospedeiro (Taylor et al., 2007). Adicionalmente, já foi verificado que a fagocitose de esporos de C. neoformans por macrófagos alveolares murinos, é dependente da via Dectina-1 (Giles et $a l ., 2009)$, Por outro lado, dois estudos demonstram que Dectina-1 pode não ser requerida para o reconhecimento de $C$. neoformans (Nakamura et al., 2007; Walsh et al., 2017). Fato este que pode ser explicado pela camuflagem da camada de $\beta$ - glucanos pela cápsula polissacarídica 
presente em C. neoformans (Cross e Bancroft, 1995) ou devido a menor abundância na parede celular como ocorre em Paracoccidioides brasiliensis (Borges-Walmsley et al., 2002).

Outro importante CLR avaliado, foi o receptor de manose (MR), o qual apresentou elevada expressão nos três órgãos analisados. Este receptor é responsável por reconhecer uma gama de ligantes, incluindo patógenos fúngicos, e por participar do processo de resposta imune (Wang et al., 2016). Diversos estudos têm mostrado aumento dos níveis de expressão desse receptor após infecção por patógenos (Xaplanteri et al., 2009; Holder et al., 2014), assim como em células epiteliais da córnea infectadas com Aspergillus fumigatus (Wang et al., 2016). Adicionalmente, MR pode ser crucial na indução da produção de IL-17 em C. albicans (Van De Veerdonk et al., 2009), e possui importante ação sinérgica com TLR4 e Dectina-1 na condução de resposta antifúngica Th17, na infecção por P. brasiliensis (Loures et al., 2015).

O estudo do papel das lectinas na resposta imune inata como moléculas de ligação a LPS, opsoninas e fatores de ativação do sistema complemento vem ganhando destaque (Garred et al., 2016). Dentre elas, lectinas tipo C como a proteína ligadora de manose (Mbl) e galectinas tem papel fundamental na neutralização do patógeno e condução da imunidade adaptativa (Vasta et al., 1999). Nossos resultados mostraram que na ausência da infecção por $C$. neoformans, o pulmão dos animais Gal-3 KO comparado aos animais WT apresentaram aumento da expressão de Mbl2, que é capaz de se ligar a diferentes açucares, incluindo GlcNAc, manose, fucose e glicose (Turner, 2003). Ainda não há estudos que mostrem relação entre Gal3 e Mbl2, entretanto, uma vez que também observamos aumento da expressão de pentraxinas e ficolinas, talvez essas interações promovem ampliação do reconhecimento de padrões moleculares e diversificação das funções efetoras imunológicas (Ma et al., 2013)

A depuração da infecção por $C$. neoformans requer imunidade TH1 com subsequente recrutamento pulmonar e ativação de leucócitos, sendo os macrófagos principais mediadores celulares no combate da infecção (Traynor e Huffnagle, 2001). As quimiocinas desempenham importante papel no recrutamento e migração de leucócitos, bem como na polarização da resposta imune Th1/Th2. Corroborando com nossos resultados que verificaram aumento na expressão de Cxc19, Cxcl10 e Ccr5, estudos anteriores demonstraram que células Th1 expressam preferencialmente receptores de quimiocinas Ccr5 e Cxcr3, os quais permitem migração dessas células para o local da infecção. Além disso, estudos in vivo demonstram aumento da expressão de Cxcr3 e seus ligantes Cxcl10 e Cxc19, e de Ccr5 no pulmão de camundongos com criptococose, correlacionando positivamente com o padrão de migração de células Th1 (Angkasekwinai et al., 2014). Também foi possível observar aumento dos níveis intrapulmonares de Ccl3 (ligante de Ccr5), Ccl2 e Cxcl5 (Traynor e Huffnagle, 2001). Ademais, 
Ccr5 desempenha um papel órgão-especifico na defesa do hospedeiro contra a infecção por $C$. neoformans (Huffnagle et al., 1999).

Souto e colaboradores avaliaram a expressão de quimiocinas e seus receptores bem como sua regulação por IFN- y na infecção por P. brasilienses. Eles observaram que assim como ocorre na criptococose, há aumento da produção de Ccl2, Ccl3, Cxcl9 e Cxcl10 bem como dos receptores Ccr5 e Cxcr3 nos pulmões de camundongos infectados. Foi verificado que o aumento de IFN-y parece aumentar a produção de Cxcl9 e Cxcl10, resultando em migração de células Th1 para o foco inflamatório (Souto et al., 2003); assim como verificado em nossos resultados, também detectamos significativo aumento da expressão de IFN- y, Cxcl9 e Cxcl10.

Direcionando nossas análises para a diminuição da expressão dos genes envolvidos na imunidade inata, foi possível observar, de forma geral, modulação negativa de transcritos envolvidos na inflamação, fagocitose, PRRs e suas vias de transdução de sinais. A ausência de Gal-3 no pulmão, baço e cérebro dos animais sem infecção promoveu diminuição da modulação de genes envolvidos na cascata do sistema complemento (C3), quimiocinas e seus receptores (Ccl20, Cxcl3 e Ccr5), citocinas pró-inflamatórias (IL-12B e IL-1 $\alpha$ ), fator de transcrição (Fos), proteínas adaptadoras e efetoras envolvidas na transdução de sinal de PRRs (MyD88 e Syk) e pentraxina neuronal 1 (Nptx1). Por sua vez, a presença da infecção por C. neoformans acarretou em diminuição de IL-12A e IL-12B, MyD88, Sky, CD209a, Fcgr1 e Fcgr4.

Nosso grupo demonstrou que a ausência de Gal-3 promove aumento da carga fúngica no pulmão e cérebro de camundongos Gal-3 KO infectados com C. neoformans (Almeida et al., 2017). Esse aumento da susceptibilidade à infecção na ausência de Gal-3 também foi relatado para outros patógenos fúngicos como C. albicans (Linden et al., 2013) e P. brasiliensis (Ruas, Luciana Pereira et al., 2009). Esses estudos sugerem que a deficiência de Gal-3 está associada com maior disseminação da infecção fúngica e comprometimento da resposta imune antifúngica Th1 e/ou Th17, corroborando com os nossos resultados de modulação negativa das citocinas pro-inflamatórias IL-12A, IL-12B e IL-1 $\alpha$ na presença ou ausência da infecção.

Relatamos que a presença da criptococose no pulmão e cérebro de animais WT e Gal-3 KO comparado aos respectivos grupos controles (WT PBS e Gal-3KO PBS), pode promover superexpressão de Dectina-1, entretanto, ao compararmos animais Gal-3KO com os WT, na ausência e presença da infecção, não observamos esta modulação positiva. Todavia, foi possível observar que a ausência de Gal-3 promove diminuição de CLR como CD209a, ou também conhecido como DC-SIGN, e de proteínas envolvidas na sua via de transdução como MyD88 e Syk. 
O receptor CD209a (DC-SIGN) é altamente expresso em CDs com reconhecimento de glicanos ricos em manose. Sua ligação a patógenos acarreta na captação e processamento de antígenos para posterior apresentação via complexo MHC (Gramberg et al., 2006). Em macrófagos murinos infectados com C. albicans, este receptor juntamente com Dectina-1 e TLR-2 induzem ao burst oxidativo e produção de TNF- $\alpha$ in vitro (Takahara et al., 2011; Takahara et al., 2012), enquanto que na infecção por $C$. neoformans, juntamente com MR, exercem papel no reconhecimento de manoproteinas presentes na cápsula do patógeno (Mansour et al., 2006). Já em relação as proteínas envolvidas na via de transdução dos CLRs, LeibundGut-Landmann e colaboradores mostram que a sinalização via Dectina-1-Syk-Card9 induziu a produção de citocinas pró-inflamatórias como IL-6, TNF- $\alpha$ e IL-23 e pouca IL-12, além da maturação de CDs e sua diferenciação para um perfil Th17. Assim, as vias de sinalização relacionadas a Syk-Card9 podem promover a ativação de CDs independente de TLRs, regulando para uma resposta Th17 em certas infecções (Leibundgut-Landmann et al., 2007). Em consonância com esses resultados, nosso grupo observou que a ausência de Gal-3 afeta a resposta imune Th17 (Almeida et al., 2017), o que poderia ser explicado com a diminuição da expressão gênica do receptor CD209a e de MyD88 e Syk, com exceção de Card9 que não apresentou alterações significativas em sua expressão.

Em relação a baixa expressão de receptores Fcgr1 e Fcgr4 provocada pela deficiência de Gal-3 durante a criptococose, estudos mostram que a utilização de anticorpos (Abs) IgG na proteção contra patógenos como vírus, bactérias, fungos e parasitas através de mecanismos efetores diretos ou indiretos vem sendo cada vez mais avaliada. Dentre as principais funções mediadas por Abs, temos neutralização de toxinas, opsonização e fagocitose, ativação do sistema complemento e indução na produção de ROS e RNS. A interação dos Abs com seus receptores $\mathrm{Fc}$ (FcRs) promove funções adicionais como: ativação celular, produção de citocinas, endocitose mediada por receptores e degradação de complexos imunes (Joller et al., 2011). Os Abs são capazes de conferir proteção contra patógenos fúngicos como C. neoformans (Mukherjee et al., 1995) e C. albicans (Hu et al., 2006). Na criptococose, a opsonização mediada por IgG1 impede o crescimento do fungo em macrófagos e promove aumento da fagocitose do fungo (Mukherjee et al., 1995), sendo esses efeitos estritamente dependente de FcR (Yuan et al., 1998). Com isso, nossos resultados podem sugerir que a diminuição da expressão desses receptores, devido à ausência de Gal-3, pode culminar em prejudicada resposta imune e a maior vulnerabilidade à infecção fúngica pelo hospedeiro. 


\section{CONCLUSÃO}

Podemos inferir que a ausência de Gal-3 no curso da infecção por $C$. neoformans promove diminuição da sobrevida dos animais, com concomitante aumento da carga fúngica nos principais órgãos acometidos por este patógeno (pulmão, baço e cérebro). Além disso, a ausência dessa lectina acarreta em alteração no perfil de resposta imune antifúngica Th17, fato esse que favorece a disseminação do patógeno e poder ser prejudicial ao hospedeiro. Concluimos também, que durante infecção por C. neoformans, Gal-3 está envolvida no aumento da expressão de PRRs responsivos a $\beta$-glucana e manose/quitina (Clec7a e Mrc1), de genes relacionados a inflamação (Cxcl1, Cxc19, Cxcl10, Ccr1, Ccr5, IL-6) e fagocitose (Sftpd) e diminuição da expressão do receptor CD209a, das citocinas pro-inflamatórias IL-12B e IL$1 \beta$ e da tirosina quinase envolvida na transdução de sinal (Syk).

Portanto, hipotetizamos que Gal-3 pode exercer importante papel frente a criptococose no desenvolvimento de resposta imune antifúngica. 
ANEXO

\section{Manuscrito:}

Fausto Almeida, Julie M. Wolf, Thiago Aparecido da Silva, Carlos M. DeLeon-Rodriguez, Caroline Patini Rezende, André Moreira Pessoni, Fabrício Freitas Fernandes, Rafael SilvaRocha, Roberto Martinez, Marcio L. Rodrigues, Maria Cristina Roque-Barreira \& Arturo Casadevall. Galectin- 3 impacts Cryptococcus neoformans infection through direct antifungal effects.

Nature communications. 2017 
ARTICLE

DOI: $10.1038 / s 41467-017-02126-7$

\section{Galectin-3 impacts Cryptococcus neoformans infection through direct antifungal effects}

Fausto Almeida', Julie M. Wolf ${ }^{2}$, Thiago Aparecido da Silva ${ }^{3}$, Carlos M. DeLeon-Rodriguez ${ }^{2}$, Caroline Patini Rezende ${ }^{1}$, André Moreira Pessoni ${ }^{1}$, Fabrício Freitas Fernandes ${ }^{3}$, Rafael Silva-Rocha ${ }^{3}$, Roberto Martinez ${ }^{4}$, Marcio L. Rodrigues (1) ${ }^{5,6}$, Maria Cristina Roque-Barreira ${ }^{3}$ \& Arturo Casadevall ${ }^{7}$

Cryptococcus neoformans is an encapsulated fungal pathogen that causes cryptococcosis, which is a major opportunistic infection in immunosuppressed individuals. Mammalian $\beta$ galactoside-binding protein Galectin-3 (Gal-3) modulates the host innate and adaptive immunity, and plays significant roles during microbial infections including some fungal diseases. Here we show that this protein plays a role also in C. neoformans infection. We find augmented Gal-3 serum levels in human and experimental infections, as well as in spleen, lung, and brain tissues of infected mice. Gal-3-deficient mice are more susceptible to cryptococcosis than WT animals, as demonstrated by the higher fungal burden and lower animal survival. In vitro experiments show that Gal-3 inhibits fungal growth and exerts a direct lytic effect on C. neoformans extracellular vesicles (EVs). Our results indicate a direct role for Gal-3 in antifungal immunity whereby this molecule affects the outcome of $C$. neoformans infection by inhibiting fungal growth and reducing EV stability, which in turn could benefit the host.

\footnotetext{
${ }^{1}$ Department of Biochemistry and Immunology, Ribeirao Preto Medical School, University of Sao Paulo, Ribeirao Preto, SP 14049-900, Brazil. ${ }^{2}$ Department of Microbiology and Immunology, Albert Einstein College of Medicine, Yeshiva University, New York, NY 10461, USA. ${ }^{3}$ Department of Cellular and Molecular Biology, Ribeirao Preto Medical School, University of Sao Paulo, Ribeirao Preto, SP 14049-900, Brazil. ${ }^{4}$ Department of Internal Medicine, Ribeirao Preto Medical School, University of Sao Paulo, Ribeirao Preto, SP 14048-900, Brazil. ${ }^{5}$ Instituto de Microbiologia Paulo de Goes, Universidade Federal do Rio de Janeiro, Rio de Janeiro, 21941-902, Brazil. ${ }^{6}$ Fundação Oswaldo Cruz-Fiocruz Centro de Desenvolvimento Tecnológico em Saúde (CDTS), Rio de Janeiro, 21041-361, Brazil. ${ }^{7}$ Department of Molecular Microbiology and Immunology, Johns Hopkins Bloomberg School of Public Health, Baltimore, MD 21205, USA. Correspondence and requests for materials should be addressed to A.C. (email: acasade1@jhu.edu)
} 
C ryptococcosis, a disease that is mainly caused by Cryptococcus neoformans, is a major infection in immunocompromised hosts, such as those with advanced HIV infection ${ }^{1}$. C. neoformans is found worldwide in various environmental niches, generally associated with avian guano or vegetation $^{2,3}$. Exposure to C. neoformans usually does not cause overt disease and the infection may lead to an asymptomatic latent state $^{4,5}$. The reactivation of infection causes pneumonia and/or meningoencephalitis, which are frequently fatal-even when treated aggressively with antifungal drug therapy ${ }^{6}$. The most important virulence factors of $C$. neoformans are the polysaccharide capsule ${ }^{7}$, cell wall-associated melanin $^{8}$, capacity to grow at body temperature ${ }^{9}$, and ability to produce extracellular enzymes ${ }^{10}$. These factors together with the host state can determine the outcome of the infection.

For all pathogenic microbes, extracellular release of molecules is a vital process ${ }^{11}$. A number of the important mechanisms through which fungal pathogens export molecules require transcell wall transport in extracellular vesicles $(\mathrm{EVs})^{11}$. EVs carry several virulence factors and may contribute with fungal virulence and modulation of host immunity ${ }^{12-15}$. Vesicular stability is assumed to be important to ensure proper delivery of their content into host tissues and cells ${ }^{16}$.

Several lectins play immunomodulatory activities, mostly through interactions between their carbohydrate recognition domains (CRD)s with the glycan moieties of receptors of immune cells. Otherwise, host lectins may interact with sugars present or released by microbial cells, and play critical roles in infections. Galectin-3 (Gal-3), an animal lectin that typically binds $\beta$-galactosides, is a pleiotropic protein intimately involved in a variety of cellular processes. Extracellular Gal-3 can modulate adhesion, activation, and cellular migration, whereas intracellular Gal-3 regulates fundamental processes such as premRNA splicing and phagocytosis ${ }^{17}$. Gal-3 plays important roles in the development and regulation of immunity homeostasis. During infections, Gal-3 exerts pro-inflammatory activity, enhances macrophages survival, and induces macrophage recruitment, antimicrobial activities, and cytokines production. Gal-3 is found deposited in pyogranuloma and granuloma in Rhodococcus equi ${ }^{18}$ and Schistosoma mansoni ${ }^{19}$ infections, respectively. During the infection caused by S. mansoni, Gal-3 binds to GalNAc $\beta 1,4 \mathrm{GlcNAc}$-containing glycans, which constitute the most common $N$-linked glycan component in invertebrates. Binding of Gal-3 to S. mansoni results in increased phagocytosis by macrophages ${ }^{19}$. In addition to its immunomodulatory roles, Gal-3 can bind to glycans on the surface of pathogens, enabling or impeding microbial invasion, supporting their survival or leading to an effective host immune response $e^{20}$. Infecting microbes, in turn, can modulate Gal-3 expression, which regulates leukocyte functions and inflammatory responses. Consequently, Gal-3 significantly influences a number of microbial infections, a knowledge that is mostly derived from comparative studies on the course of models in Gal-3KO and WT mice $17,18,21-23$

Mycoses whose course is influenced by Gal-3 include those caused by Paracoccidioides brasiliensis ${ }^{23}$, Candida albicans ${ }^{24}$, and Histoplasma capsulatum ${ }^{25}$. Nevertheless there are no studies focusing on the role played by Gal-3 in cryptococcosis. In this study, we compared the severity of the $C$. neoformans infection in Gal-3KO and WT mice, assessed the Gal-3 content in organs of infected mice, and determined the Gal-3 serum levels in both experimental and human cryptococcosis. We also evaluated whether Gal-3 influenced C. neoformans growth and stability of EVs. Our results demonstrate that Gal-3 plays relevant roles in $C$. neoformans infection primarily through direct effects on cryptococcal cells and their products.

\section{Results}

Gal-3 is upregulated during $C$. neoformans infection. Since augmented Gal3 expression was previously reported during human and experimental inflammatory diseases ${ }^{26,27}$, we determined Gal-3 levels in tissues and serum of C57BL/6 mice on days 3,7 , and 14 post-infection with $C$. neoformans. In comparison with control animals, infected mice had higher Gal-3 levels in all examined tissues and serum samples (Fig. 1). In brain samples (Fig. 1a), Gal-3 levels were increased in mice on days 3, 7, and 14 post-infection. Similar results were observed in spleen samples (Fig. 1b), although statistical differences between control and infected animals were observed only in days 7 and 14 postinfection. In lung and serum samples (Fig. 1c, d, respectively), Gal-3 levels were higher only at day 14 post-infection. We concluded that the C. neoformans infection in mice led to increases in tissue and serum Gal-3 content, with a variable time-course depending on the tissue.

We then measured Gal-3 levels in serum samples from individuals suffering of cryptococcosis, belonging to groups of patients who were immunocompetent (IC) or HIV-positive. An additional control group, constituted by healthy individuals, was assessed for the Gal-3 serum levels. Compared to the healthy individuals, the IC and HIV+ patients showed higher Gal-3 serum levels, possibly attributed to the concurrent cryptococcosis (Fig. 2). There was no significant difference ( $p$-value: $0.0926, t$ test) between the Gal-3 levels in sera of IC and HIV+ patients with cryptococcosis. These results reinforce the notion, derived from the experimental studies, that there is a relation between $C$. neoformans infection and increased levels of serum Gal-3.

Gal-3 contributes to the control of the C. neoformans infection. To investigate whether the Gal-3 upregulation could influence the host resistance to the $C$. neoformans infection, we compared survival levels and fungal burden of Gal-3-deficient $\left(\right.$ gall $\left.^{-/-}\right)$and WT mice. Gal-3-deficient mice died faster than WT animals (Fig. 3a). These results were supported by quantification of fungal burden in organs of both groups of mice. We recovered higher colony-forming units (CFU) from the lungs harvested at 3, 7, and 14 days post-infection from gal $^{-/-}$mice than from WT mice (Fig. 3a). Regarding the brain, we recovered higher CFU number from gal3 $^{-/}$than from WT mice at 14 days post-infection (Fig. 3b). The set of experimental observations reported in this section reveals that Gal-3 is implicated in the control of the $C$. neoformans infection.

Gal-3 deficiency affects TH17 immune response. We investigated whether the Gal-3 absence or presence drive distinctly the immune response toward the Th1, Th2 or Th17 axis during a $C$. neoformans experimental infection. To do so we assessed the cytokine content in the brain, lungs, and spleen, which were harvested at 3,7 , and 14 days post-infection from WT and gal3 ${ }^{-1-}$ mice. The IFN- $\gamma$, IL-12p40, IL-6, TNF- $\alpha$, IL-10 contents in the brain and lung homogenates did not differ between WT and gal $3^{-/-}$groups of mice, in all infection period (Fig. $4 \mathrm{a}-\mathrm{e}, \mathrm{h}-\mathrm{l}$, respectively). In contrast, the concentration of IL-12p40, IL-6, and TNF- $\alpha$ in the spleen homogenates from WT mice were higher than in gal $3^{-/}$mice (Fig. $4 \mathrm{p}-\mathrm{r}$ ), whereas the spleen contents of IFN- $\gamma$ and IL-10 were similar between the two groups of mice (Fig. 4c, s). Surprisingly, IL-17 and IL-23 contents in the lungs and spleen were higher than in gal $3^{-/}$ mice (Fig. $4 \mathrm{~m}, \mathrm{n}, \mathrm{t}, \mathrm{u}$ ). We also evaluated the frequency of $\gamma \delta \mathrm{T}$ cells in pulmonary tissue at 3 days post-infection, which revealed that $\gamma \delta$ $\mathrm{T}$ cells were more frequently detected in WT animals, in comparison to gal $3^{-/-}$mice (Supplementary Figure 1). This observation was in agreement with IL-17 detection in infected lungs. In addition, we evaluated the relative expression of transcription factors involved in 
a

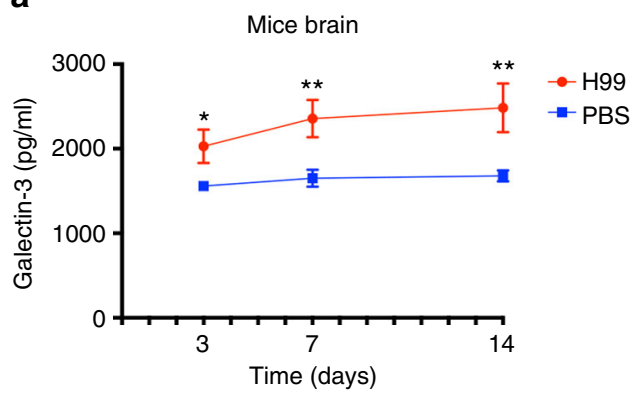

C

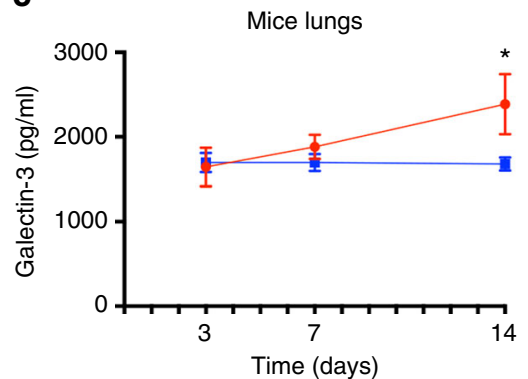

b

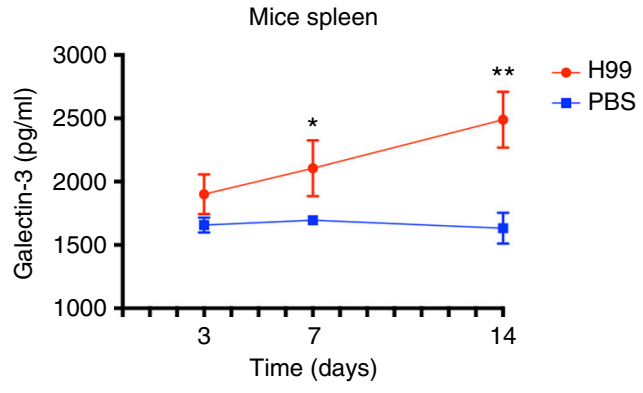

d

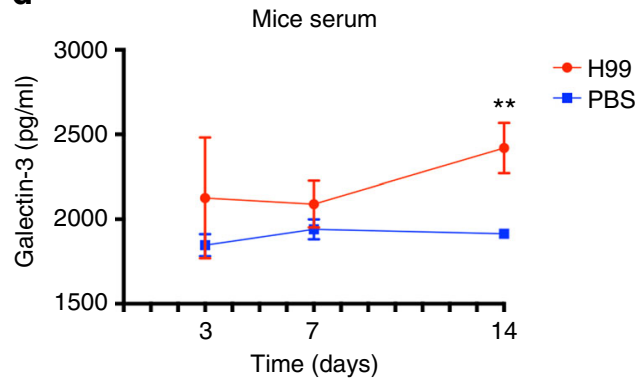

Fig. 1 Upregulated Gal-3 levels in mice during experimental C. neoformans infection. C57BL/6 mice were intratracheally infected with H99 yeast cells (red line with circle) or PBS (blue line with square) and Gal-3 levels were verified in tissues and serum during the course of $C$. neoformans infection. On days 3, 7, and 14 after the fungal inoculation, samples collected of brain (a), spleen (b), lungs (c), and serum (d), were homogenized and assessed by ELISA regarding the Gal-3 concentration. Gal-3 levels were upregulated over time after infection with C. neoformans. Bars represent the mean \pm SD of Gal-3 levels obtained from triplicate samples in groups of five animals. Statistically significant differences are denoted by asterisks $\left({ }^{\star} p<0.05,{ }^{\star \star} p<0.005,{ }^{*}\right.$ unpaired Student's $t$-test)

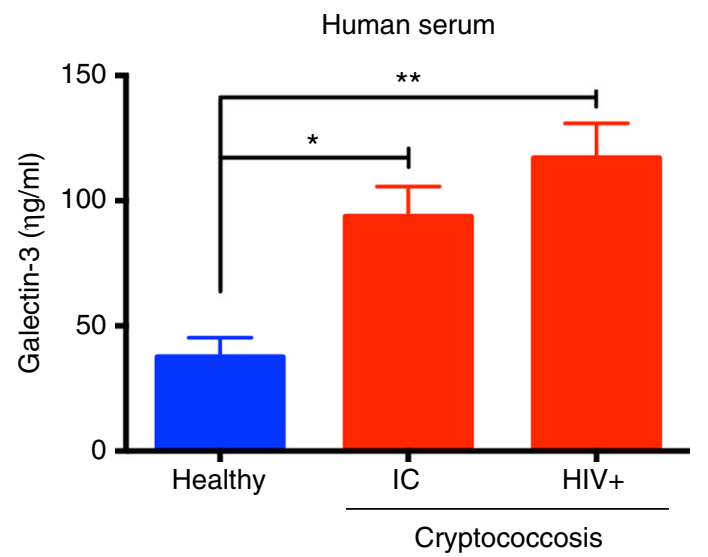

Fig. 2 Upregulated Gal-3 levels in humans during C. neoformans infection. Gal-3 levels in serum from healthy individuals (blue bar) and patients infected by $C$. neoformans (red bars) were assessed by ELISA. Gal-3 levels were higher in IC (immunocompetent) and HIV (human immunodeficiency virus) patients infected with $C$. neoformans when compared with healthy individuals. Bars represent the mean $\pm \mathrm{SD}$ of Gal-3 levels obtained from triplicate samples. Statistically significant differences are denoted by asterisks $\left({ }^{\star} p<0.05,{ }^{\star \star} p<0.005\right.$, unpaired Student's $t$-test)

T-cell differentiation, namely T-bet (for Th1 cells), GATA-3 (for Th2 cells), and ROR- $\gamma$ t (for Th17 cells) and found that the three transcription factors at days 3,7 , and 14 post-infection were similarly expressed in WT and gal3 $3^{-1-}$ mice (Fig. 5). These results suggest that the Gal-3 role in the control of the C. neoformans infection promotes skewed $\mathrm{TH} 17$ immune response profile.

Gal-3 inhibits the fungal growth. Since the role of Gal-3 in the experimental C. neoformans infection was not clearly related to an adaptive immune response, we investigated whether Gal-3 could directly recognize fungal surface sugars and consequently affect fungal cell physiology. Gal-3 promoted a dose-dependent delay in the growth of encapsulated cells of $C$. neoformans (Fig. 6a). Gal-3 did not affect the proliferation of a C. neoformans acapsular strain (CAP67, Fig. 6b). Similar results were obtained by CFU determination (Fig. $6 \mathrm{c}, \mathrm{d}$ ) and propidium iodide staining (Fig. 6e). Flow cytometry assessment of the Gal-3 binding to H99 and CAP67 C. neoformans cells showed that Gal-3 bound to the capsular H99 cells and not to the acapsular CAP67 cells. Denatured Gal-3 did not bind to the yeasts surface (Fig. 6f). Wheat germ agglutinin (WGA), used as a positive control, bound to yeasts of both strains (Fig. 6f). Confocal microscopy demonstrated that Gal-3 co-localized with the cryptococcal capsule (Fig. 6g and Supplementary Figure 2). These results suggest that the recognition of the fungal capsule by Gal-3 may account for its effect of inhibiting the in vitro $C$. neoformans growth.

We also studied the effect of Gal-3 on the cell body and capsule dimensions of $C$. neoformans after $72 \mathrm{~h}$ in the presence of Gal-3 $(10 \mu \mathrm{g} / \mathrm{ml})$. Compared to the control culture (phosphate-buffered saline (PBS)), the yeasts grown in the Gal-3 presence had reduced sizes of cell body and capsule (Fig. 6h, i, respectively).

To investigate the potential mechanisms involved in the Gal-3mediated inhibition of $C$. neoformans growth, RNA-seq analysis was performed after the fungus was exposed to Gal-3. This analysis demonstrated Gal-3 exposure resulted in upregulation of 954 genes and downregulation of 1149 genes (Supplementary Data 1-4). Within the upregulated genes, 420 had annotated functions and 534 were hypothetical, while for the downregulated genes 750 were known and 399 were hypothetical. The 40 most affected upregulated and downregulated genes are listed in Tables 1 and 2, respectively. In these groups, upregulated genes were mostly related to membrane proteins, with a clear association with sugar transport. Downregulated genes were mainly related to proteins of the large and small ribosome 
a

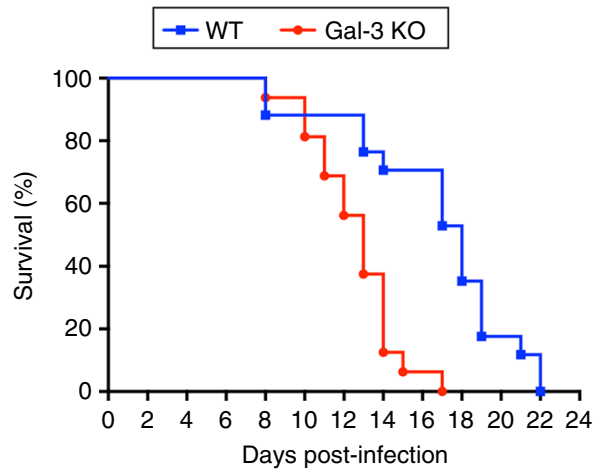

b
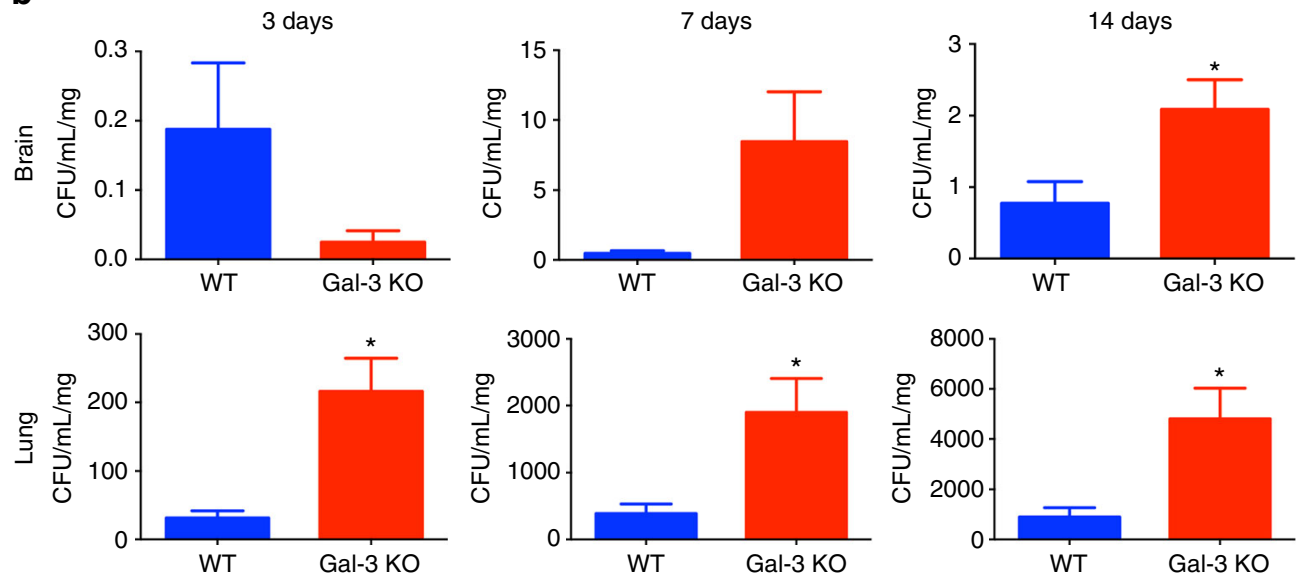

Fig. 3 Absence of Gal-3 leads to lower survival and increased fungal burden in experimental murine cryptococcosis. The survival rate (a) of Gal-3 KO mice (red line with circle) and WT mice (blue line with square) were verified after intratracheally infection with H99 yeast cells. b Colony-forming units (CFU) recovered from brain and lungs of WT (blue bars) and Gal-3 KO (red bars) mice were assessed after 3, 7, and 14 days after intratracheally infected with C. neoformans. The $y$-axis denotes $\mathrm{CFU} / \mathrm{ml} / \mathrm{mg}$ resulting from normalization of fungal burden to the weight of the organ fragment used to prepare the homogenate. Data are representative of three experiments, each performed with eight mice per group. The bars represent the mean \pm SD of CFU obtained from triplicate samples in groups of eight animals. ${ }^{\star} p<0.05$, Student's $t$-test, Gal-3 KO mice compared with WT mice

subunits. Gene ontology (GO) analysis of repressed genes showed enrichment in genes related to ribosomes, ATP synthesis, mitochondria, and integral components of the plasma membrane, suggesting a general interference with energy metabolism. On the other hand, GO analysis of upregulated genes showed enrichment in genes related to protein kinases, dioxygenase, hydrolases, transmembrane transport, and intracellular processes.

Gal-3 disrupted $C$. neoformans extracellular vesicles. Exposure of fungal EVs to macrophages or bovine serum albumin (BSA) causes vesicular disruption ${ }^{16}$. On the basis that EVs contain capsular components ${ }^{14}$ and that Gal-3 interacted with the capsule of C. neoformans, we asked whether Gal-3 would affect the physicochemical properties of EVs. Addition of Gal-3 to EVs samples resulted in the shift of a vesicular average size from 150 $\mathrm{nm}$ to below the detection limit (approximately $30 \mathrm{~nm}$ ) within 90 s (Fig. 7a). No other lectins caused similar effects (Fig. 7b). We then evaluated the involvement of the Gal-3 CRD in the putative vesicular disruption. Samples of Gal-3 that were boiled or preincubated with its glycoligand ( $\mathrm{N}$-acetyl-lactosamine) had no lytic effect on C. neoformans EVs (Fig. 7c), indicating that the Gal-3 CRD is crucial for the Gal-3 lysing activity. Similar results were obtained from assays using radiolabeled vesicles. Gal-3 promoted vesicular disruption and consequent radioactive release in a dosedependent fashion (Fig. 7d). Radioactive assays confirmed that non-related lectins were unable to lyse C. neoformans EVs (Fig. 7e). The radioactive assay also confirmed that denaturation or pre-incubation with lactosamine inhibited the Gal-3-induced EV (Fig. 7f).

Gal-3 impacts the ability of macrophages to disrupt and internalize EVs. Gal-3 is expressed and functional in most macrophage populations ${ }^{28-30}$. Since macrophages ${ }^{16}$ and Gal-3 (this study) can disrupt EVs, we asked whether these events would be correlated. Treatment of macrophages with radiolabeled vesicles suggested that WT phagocytes were approximately three times more efficient than Gal- $3^{-/-}$cells to disrupt EVs. In addition, we verified that the uptake of radioactive signal by WT peritoneal macrophages have progressively augmented, whereas the uptake by Gal-3 $3^{-/}$macrophages was permanently lower (Fig. 8).

\section{Discussion}

In the current study, we report for the first time the diverse roles played by Gal-3 in C. neoformans infection. Virtually all bacterial and eukaryotic cells display surface glycans that may be targeted by host carbohydrate-binding proteins. The established interactions frequently influence the microorganism pathogenesis, the host immune response or the occurrence of intracellular parasitism $^{31}$. Galectin-3, a member of the galectin family of beta- 

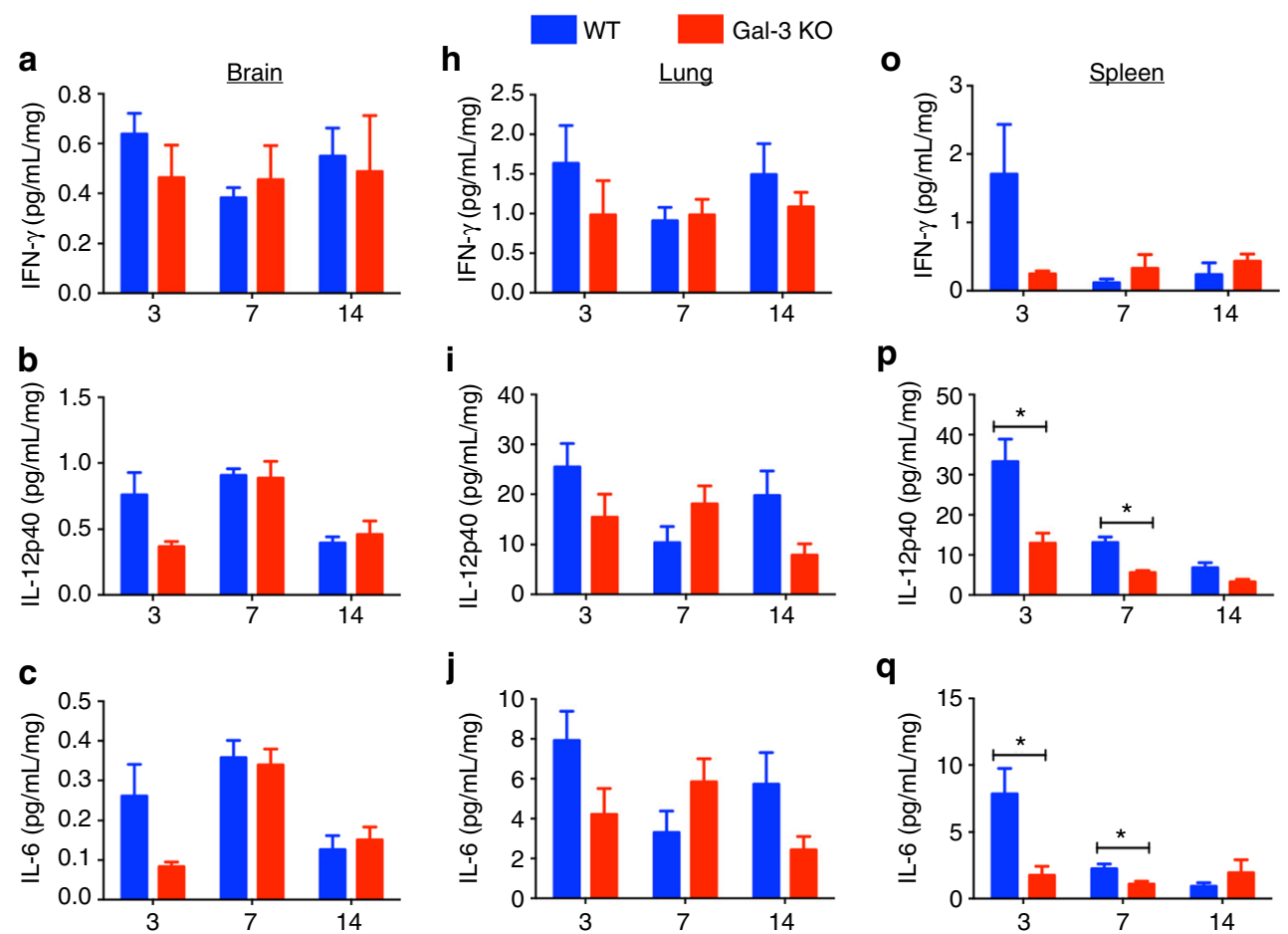

\section{$\mathbf{q}$}

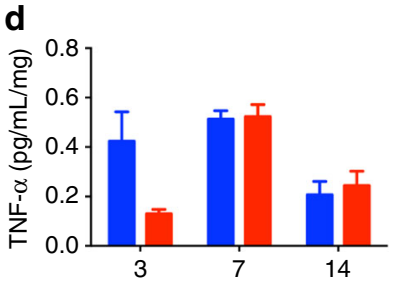

$\mathbf{k}$

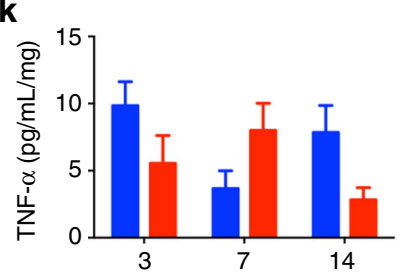

e 1
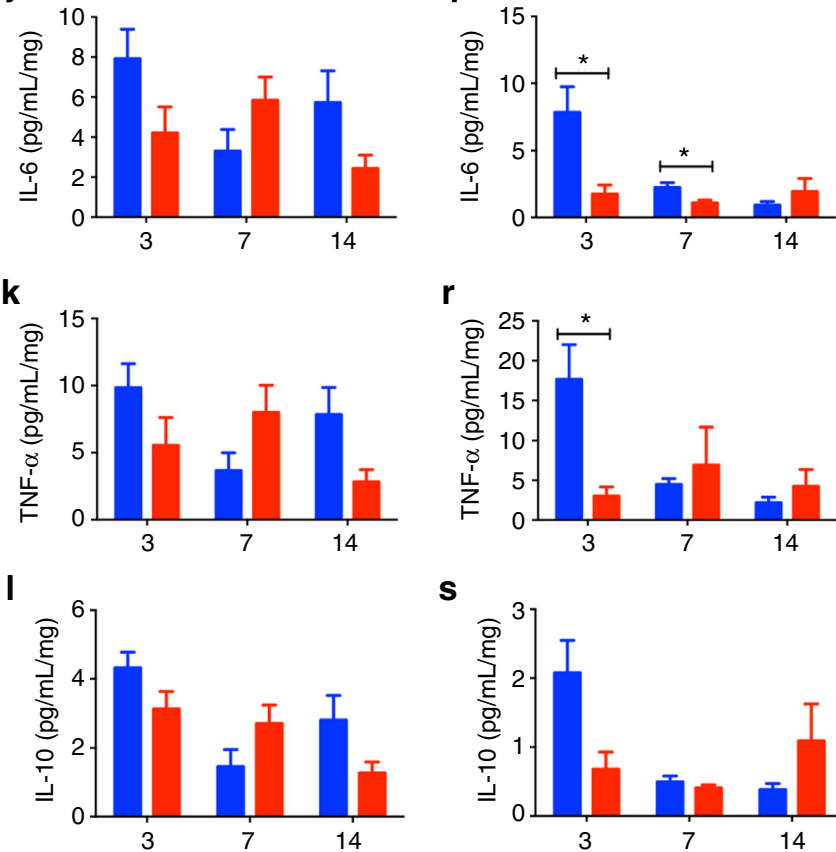

$r$
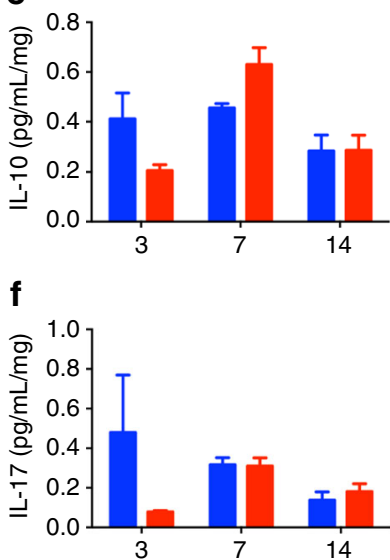

m
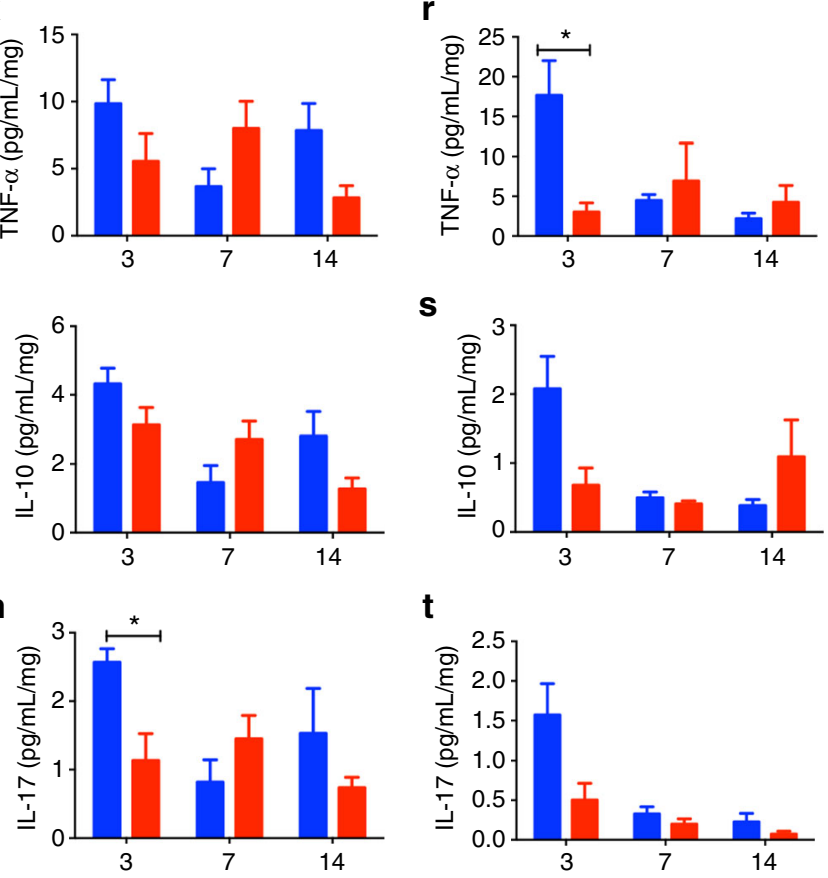

s

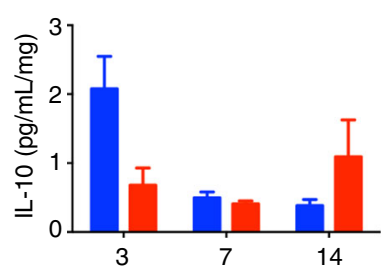

$\mathbf{t}$
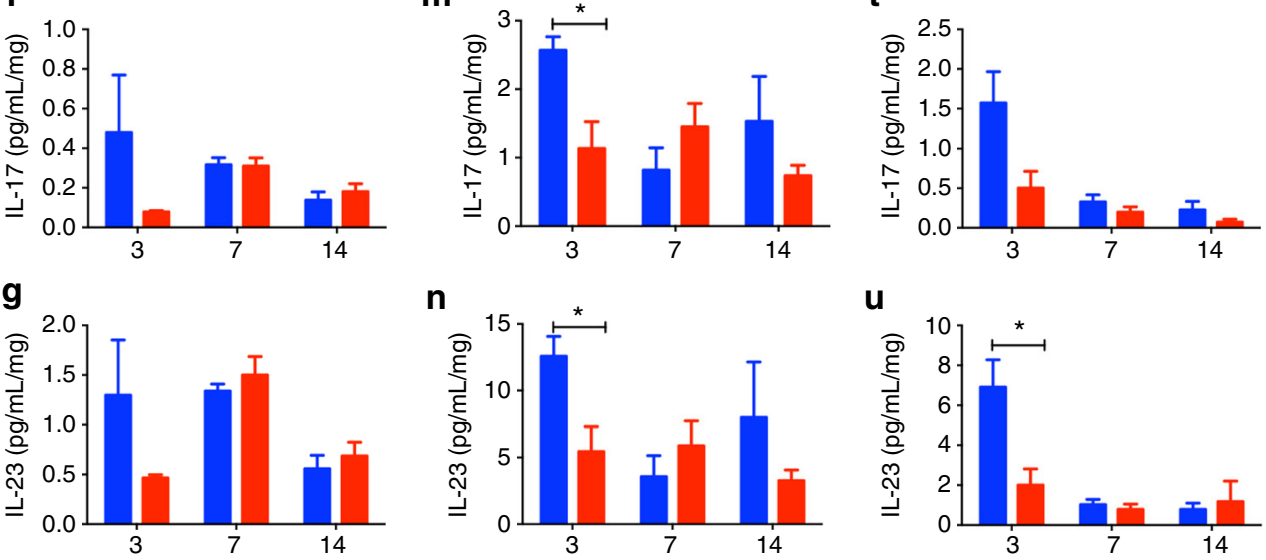

$\mathbf{u}$

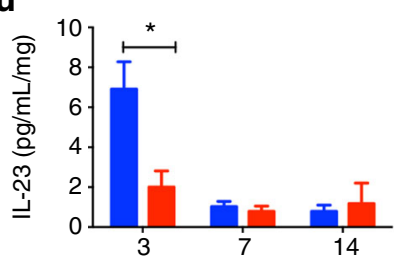

Fig. 4 Levels of relevant cytokines in the brain, lung, and spleen of C. neoformans-infected WT and Gal-3 KO mice. WT (blue bars) and Gal-3 KO (red bars) mice were intratracheally infected with a $50 \mu$ suspension containing $1 \times 10^{6}$ yeast cells. Organ samples were weighed and homogenized. The levels of the following cytokines in the brains (a-g), lungs (h-n), and spleens (o- $\mathbf{u})(3,7$, and 14 days post-infection) of infected mice were determined by ELISA: IFN- $\gamma$, IL-12p40, IL-6, TNF- $\alpha$, IL-10, IL-17, and IL-23. The results represent the mean \pm SD of five mice per group, from a representative experiment of three assays. ${ }^{\star} p<0.05$, Student's $t$-test, Gal-3 KO mice compared with WT mice 

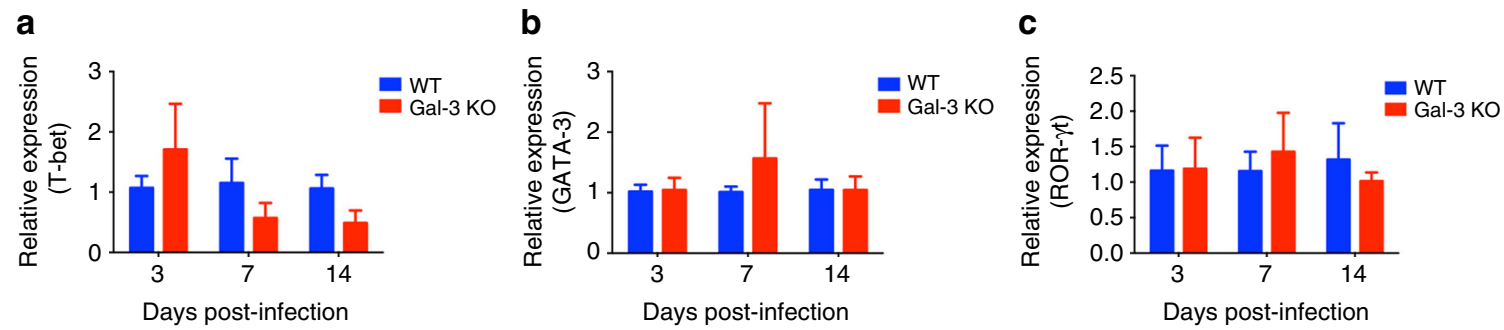

Fig. 5 Levels of T-bet, GATA-3, and ROR- $\gamma$ t in the lungs of C. neoformans-infected WT and Gal-3 KO mice. WT (blue bars) and Gal-3 KO (red bars) mice were intratracheally infected with $\mathrm{H} 99$ yeast cells and samples of their lungs weighed and homogeneized. The levels of mRNA relative expression for T-bet (a), GATA-3 (b), and ROR- $\gamma$ t (c) in the lungs (3, 7, and 14 days post-infection) of infected mice were determined by real-time PCR, using the $\beta$-actin gene as control. The results represent the mean \pm SD of five mice per group, from a representative experiment of three assays

galactosides-binding proteins is known by its ubiquitous occurrence throughout the animal species, large distribution in mammals' tissues, and wide functional diversity ${ }^{32}$.

Activated macrophages express large amounts of Gal-3, which predominates in the cytoplasm ${ }^{33}$. The nucleus, the cell surface, and the extracellular environment are additional sites where Gal3 can be detected. This distribution is compatible with the multifunctionality of Gal-3 (reviewed by ref. ${ }^{33}$ ). Relevant roles are attributed to Gal-3 interactions established during infections (reviewed by ref. ${ }^{31}$ ). The successive studies made clear that Gal-3 binding to microbial glycans can positively or negatively regulate pathogen attachment, invasion, and survival, as well as host responses that mitigate microbial pathogenesis ${ }^{20}$.

Knowledge on the functions of Gal-3 in fungal infections is still preliminary. In experimental models of paracoccidioidomycosis and histoplasmosis, Gal-3 influenced the host response by regulating cytokine production ${ }^{23}, 25$. In paracoccidioidomycosis, Gal-3 favored the development of detrimental Th2 immune response, associated with severe disease ${ }^{23}$. Gal-3 was also detrimental to the host resistance against histoplasmosis by negatively regulating IL17-A responses, which was attributed to inhibition of the IL-23/IL17 axis in dendritic cells ${ }^{25}$. These data are consistent with the in vitro demonstration that Gal-3 modulates Th17 response by regulating dendritic cells cytokines ${ }^{34}$. Since Th17 responses are known to be critical in conferring protection against fungal infection, the herein mentioned studies support the notion that Gal-3 plays a negative role in the induction of antifungal immunity. This notion was not supported by our current data showing augmented contents of IL-17, IL-23, IL-12p40, and IL-6, in organs of Gal-3-proficient mice infected with C. neoformans. Our current work suggests that Gal-3 may favor the occurrence of a skewed Th17 immune response. Since we did not detect any increase of IFN- $\gamma$, we attribute the elevated detection of IL-12p40 to increased production of IL-23, since this cytokine shares the p40 subunit of IL-12. The occurrence of Th17 immunity in the Gal-3-proficient mice infected with $C$. neoformans was reinforced by the augmented detection of IL-6, which is an inductive signal for the IL-17 production by Th17 cells. Moreover, the IL-17 level detected in infected lungs is consistent with that reported by other studies ${ }^{35,36}$. In fact, IL-17 and Th17 responses are important for the clearance of pulmonary cryptococcosis $^{35-38}$.

The studies performed in models of experimental candidiasis have afforded the most important information available on the roles played by Gal-3 in fungal infections. These showed Gal-3 participation $^{24,34,39}$ in the generation of Th17 protective immunity against candidiasis (reviewed by ref. ${ }^{40}$ ), a phenomenon verified in this study for C. neoformans. The studies on experimental candidiasis revealed also that interaction with Gal-3 is responsible for several macrophages responses previously reported as stimulated by $\beta-1,2$-linked oligomannosides of $C$. albicans ${ }^{41}$. The identification of Gal-3 as macrophage receptor for $\beta$-1,2-linked oligomannosides was surprising, since members of the galectin family are defined by a common carbohydrate-recognition domain with affinity for $\beta$-galactosides ${ }^{42}$. Nonetheless the Gal-3 binding to $\beta-1,2$ oligomannosides was largely certified and found triggering macrophages relevant responses, such as increased TNF- $\alpha$ production and fungicidal effect, which account for the death of Candida species ${ }^{43}$. Consistently, C. albicans infection of $\mathrm{Gal}-3^{+/+}$ and Gal- $3^{-/-}$mice showed an association of the deficiency of Gal-3 to the increased susceptibility to the fungal disease ${ }^{24}$; although involvement of Th17 immune response was not explored in their model. We also verified that Gal- $3^{-1-}$ mice are more susceptible $C$. neoformans infection, and demonstrated that only Gal- $3^{+/+}$mice exhibited increased tissue content of IL-17/IL-23 cytokines. Considering the studies on candidiasis, we hypothesized that Gal-3 binding to the $C$. neoformans capsule could occur through the recognition of $\beta-1,3$ mannosides. However, the known structures of capsular GXM and GalXM contain only $\beta-1,2$ mannosides, which are supposedly not recognized by Gal- $3^{44,45}$. Furthermore, the occurrence of oligosaccharides with terminal $\beta$-galactoside, which is the most common ligand of Gal-3, was not verified in $C$. neoformans. Therefore, further investment on the identification of the glycoconjugate targeted by Gal-3 is necessary to clarify this important issue.

The finding that Gal-3 had a fungistatic effect for C. neoformans suggests that this molecule has a role in antifungal defense. To understand how Gal-3 could be mediating its effects, we analyzed C. neoformans gene expression in its presence and absence. We observed upregulation of genes related to membrane proteins, mainly those involved with sugar transport. Downregulated genes mostly included those related ribosomal activities, suggesting ablation of the functions housekeeping energy-related molecules. Gal-3 caused disruption of C. neoformans EVs, as well as an efficient uptake of EV contents by macrophages. Identification of the target of Gal-3 in EVs was beyond the scope of the current study, but GXM and GalXM are natural candidates. Serum albumin, a protein used as a positive control in our assays, was previously reported as a vesicle-destabilizing factor in tissue culture medium ${ }^{16}$. The mechanism of disruption remains undefined, but albumin binds fatty acids ${ }^{46}$ and sterols ${ }^{47}$ and likely induces membrane destabilization. Gal-3-induced vesicle lysis, however, might be a novel immunological mechanism because it defeats the putative role of vesicles in delivering a concentrated punch of virulence factors and instead could result in the release and dilution of fungal components into host cells and tissues. The transcriptional changes observed with Gal-3 C. neoformans imply cellular stress, which combined with the observation that this protein disrupts vesicles, leads to the suggestion that its mechanism of action may be membrane damage that is sufficient to inhibit replication of fungal cells. Thus, increased Gal-3 levels during infection could protect the host by interfering with vesicle- 
mediated delivery of components that promote C. neoformans virulence and inhibiting fungal growth.

Taken together, our findings suggest multiple roles for Gal-3 in cryptococcal infection. Gal-3 functions in host defense against C. neoformans more by interfering with fungal physiology through delayed replication, capsular binding, and vesicle disruption than by its effects on the inflammatory response. In this regard, the role of Gal-3 in host protection against
C. neoformans appears to differ for the effects described with other mycoses. Galectins are known to have direct antimicrobial effects on variety of bacteria and are fungicidal to C. albicans ${ }^{43}$. Hence, Gal-3 appears to be part of innate immunity against C. neoformans. These results provide a new window on our understanding of the immunopathogenesis of cryptococcosis and suggest a novel target for the design of therapeutic agents to combat this mortal mycosis.
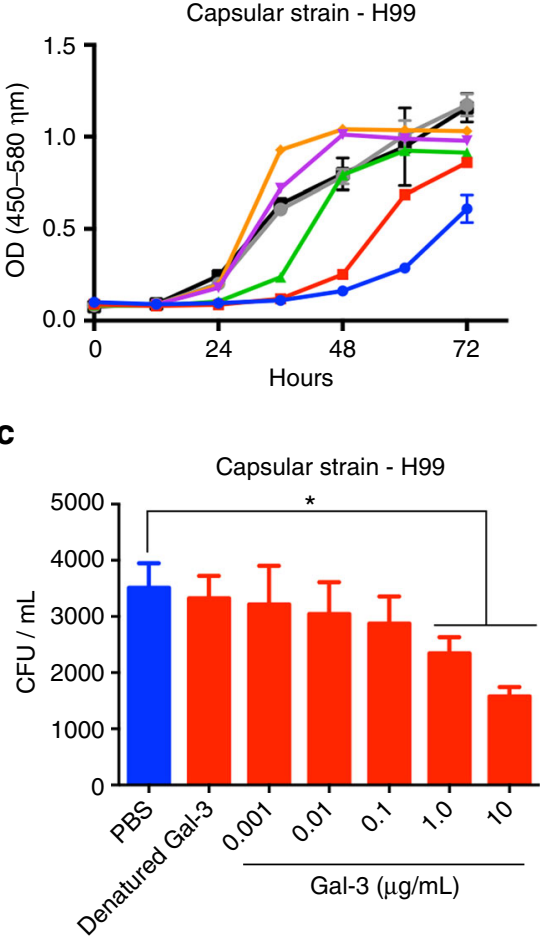

b

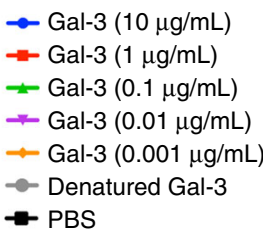

d

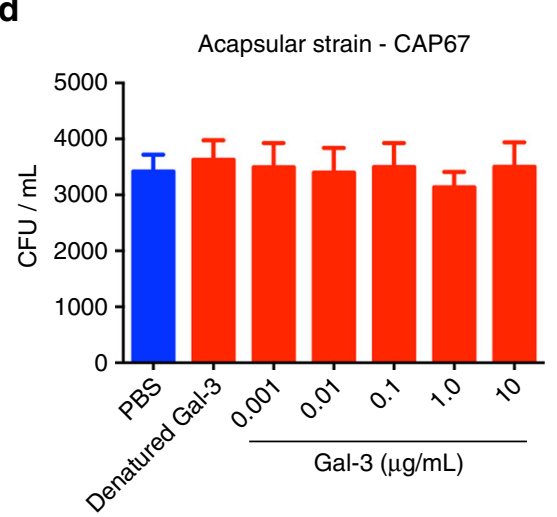

Acapsular strain - CAP67

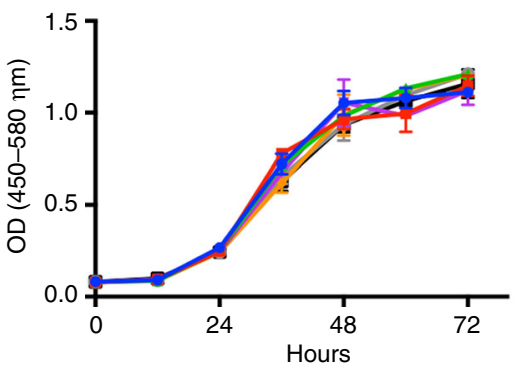

$\rightarrow$ Gal-3 $(10 \mu \mathrm{g} / \mathrm{mL})$

- Gal-3 $(1 \mu \mathrm{g} / \mathrm{mL})$

- Gal-3 $(0.1 \mu \mathrm{g} / \mathrm{mL})$

- Gal-3 $(0.01 \mu \mathrm{g} / \mathrm{mL})$

$\rightarrow$ Gal-3 $(0.001 \mu \mathrm{g} / \mathrm{mL})$

$\rightarrow$ Denatured Gal-3

- PBS

e

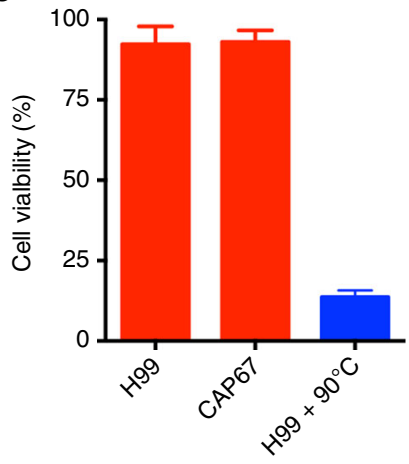

f

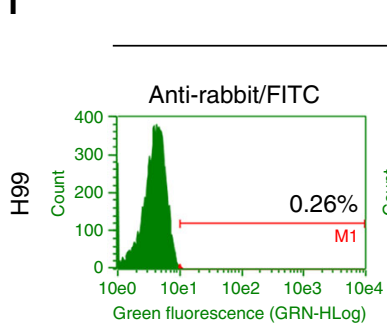

Ctrl

Gal-3
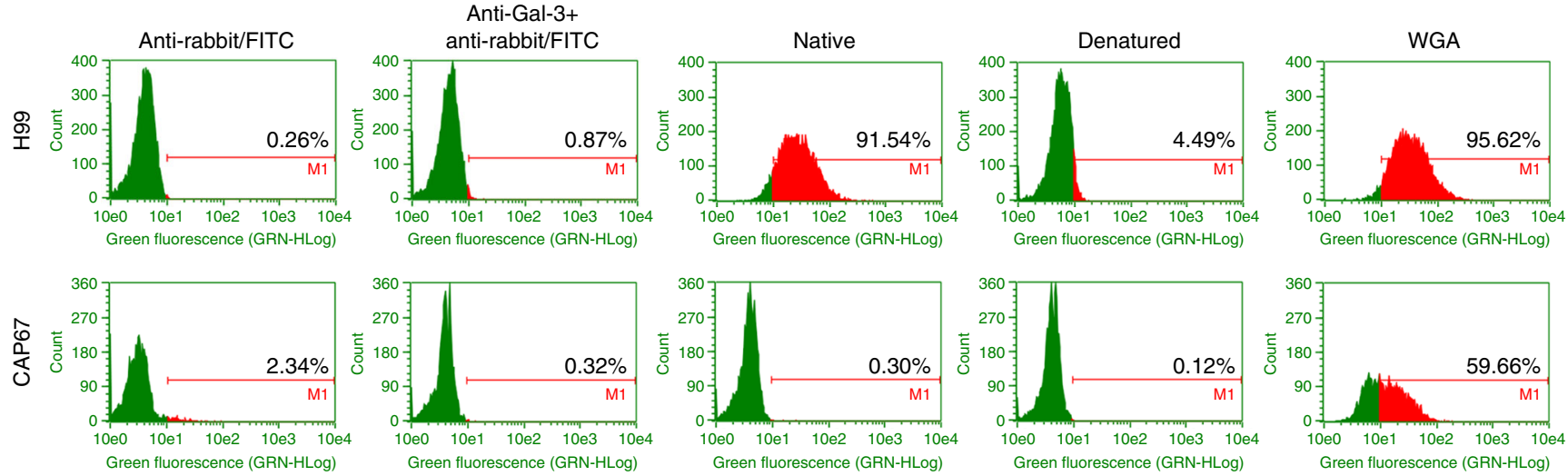

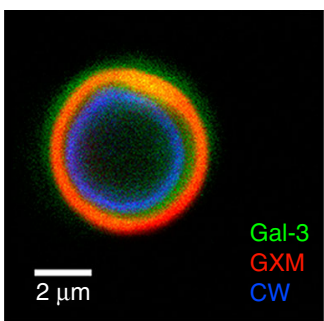

h

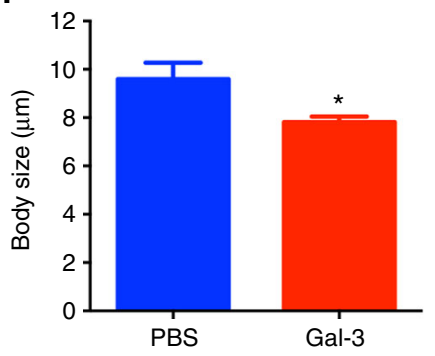

i

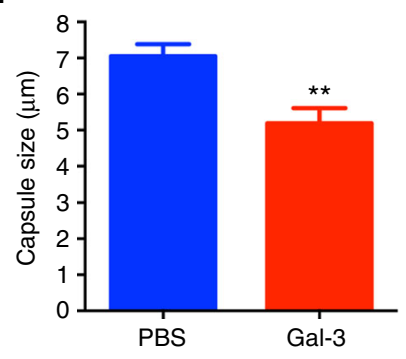




\section{Methods}

Ethics statement. All animal use complied with the standards described in Ethical Principles Guide for the Care and Use of Laboratory Animals adopted by the Brazilian College of Animal Experimentation and Albert Einstein College of Medicine Institutional Animal Care and Use Committee guidelines. The protocols were approved by the Committee of Ethics in Animal Research of the Ribeirao Preto Medical School at the University of Sao Paulo (protocol 100/2015). Informed written consent from all participants was obtained. The studies involving patients were approved by the Research Ethics Committee of the University Hospital, Ribeirao Preto Medical School at the University of Sao Paulo (protocol HCRP $4.096 / 2012)$

Mice and C. neoformans isolates. We used male C57BL/6 (wild-type, WT, Jax 000664) and Gal-3-deficient mice ( $\left.\mathrm{gal}^{-/}\right)$at $6-8$ weeks of age. Knockout mice were kindly donated by F.T. Liu (University of California, Davis, CA). Gal $3^{-/-}$mice were previously generated as described and bred on the C57BL/6 mouse background for nine generations ${ }^{48}$. The animals were housed in the animal facility of the Ribeirao Preto Medical School, University of São Paulo, under optimized hygienic conditions. All C. neoformans experiments were conducted with the clinical isolate H99 strain (serotype A) or C. neoformans acapsular strain (CAP67). The C. neoformans H99 strain was generously provided by John Perfect (Durham, NC) and the CAP67 strain was purchased from the American Type Culture Collection (Manassas, VA). Fungal cultures were grown in minimal medium composed of dextrose $(15 \mathrm{mM}), \mathrm{MgSO}_{4}(10 \mathrm{mM}), \mathrm{KH}_{2} \mathrm{PO}_{4}(29.4 \mathrm{mM})$, glycine $(13 \mathrm{mM})$, and thiamine- $\mathrm{HCl}(3 \mathrm{M})$. Fungal cells were cultivated at room temperature (RT) with continuous shaking (150 rpm). To maintain fungal virulence, serial passages in $\mathrm{C} 57 \mathrm{BL} / 6$ mice were performed before the isolate H99 was used in experiments.

\section{C. neoformans infection and survival analysis. The H99 strain was grown in} minimal medium until late logarithmic phase, washed and suspended in PBS. The concentration of yeast cells was determined by hemocytometer, and a suspension of $1 \times 10^{6} \mathrm{cells} / \mathrm{ml}$ was used to infect the mice via intratracheal with $50 \mu \mathrm{l}$ of solution. The WT and gal $3^{-1-}$ mice were anesthetized with xylazine $(125 \mathrm{mg} / \mathrm{kg})$ and ketamine $(10 \mathrm{mg} / \mathrm{kg})$ in PBS, and their necks were hyperextended and their trachea was exposed after incision. The infection with $C$. neoformans used a syringe 26gauge, and the incision was sutured with $5-0$ silk. The inocula of $5 \times 10^{5}$ cells were realized to measure the fungal burden, the levels of cytokines, or the relative expression of transcription factors in the brain, lung, spleen, and serum. These measurements were evaluated on days 3,7 , and 14 days after infection. The infection with $1 \times 10^{5}$ yeast cells was performed to survival analysis of WT and $\mathrm{gal}^{-/-}$mice, which were monitored daily for mortality. The concentration of inocula was confirmed by plating on Sabouraud Dextrose Agar (Difco, Detroit, MI, USA) and counting the CFU.

Organ fungal burden. The $C$. neoformans burden was quantified in brain and lung homogenates. Sample of homogenate was diluted in sterile PBS buffer (pH 7.2) and aliquots of $100 \mu \mathrm{l}$ were plated in Sabouraud agar medium. After $48 \mathrm{~h}$ of incubation at $30^{\circ} \mathrm{C}$, the $\mathrm{CFU}$ were counted and calculated the concentration of yeast cells $/ \mathrm{ml}$. These values were related to organ mass and the C. neoformans burden for each organ was expressed as $\mathrm{CFU} / \mathrm{ml} / \mathrm{mg}$ of tissue.

Sera and patients. Blood samples were obtained from patients being seen in the University Hospital, Ribeirao Preto Medical School at the University of Sao Paulo. A total of six patients with diagnosed cryptococcosis were included in this study: three patients with HIV and three patients IC. Serum was obtained and stored at $-80^{\circ} \mathrm{C}$. Samples were also obtained from three blood donors with a median age of 30 years (range, $25-35$ years).
Gal-3 levels. The Gal-3 levels in the brain, lung, and spleen was quantified in the organ homogenates of C. neoformans-infected mice. The homogenate samples (whole organ in $1 \mathrm{ml}$ of PBS) of control mice or from animals infected with $C$. neoformans, as well as the serum samples from infected animals or from patients with diagnosed cryptococcosis, were stored at $-80^{\circ} \mathrm{C}$ until assayed. All samples were thawed only once prior to use. Gal-3 levels were measured using commercially available enzyme-linked immunosorbent assay (ELISA) kits (Sigma-Aldrich, St. Louis, MO, USA) according to the manufacturer's instructions.

Growth in the presence of Gal-3. Cryptococcus neoformans strains H99 (capsular) and CAP67 (acapsular) cells were grown in Sabouraud medium at $37^{\circ} \mathrm{C}$ with 150 $\mathrm{rpm}$. To verify the Gal-3 effect on the cells, we performed growth curves in Sabouraud liquid medium containing different concentrations of Gal-3 (Gal-3 human recombinant, expressed in E. coli, Sigma-Aldrich) in a 96-well plate (Costar, NY, USA) using an iEMS spectrophotometer (Thermofisher). The optical density at $540 \mathrm{~nm}$ (OD540) was measured every hour, and graphs plotted using GraphPad Prism Software version 6.0 (GraphPad Software, San Diego, CA, USA).

To measure the capsule and body size of the cells, we analyzed H99 strain after $72 \mathrm{~h}$ of Gal-3 treatment and compared to the cells treated with PBS. Suspensions of India ink were photographed and measured. Image acquisition was done at differential inference contrast objective in a SP5 confocal inverted microscope equipped with a camera. Images were processed using Leica Microsystems and ImageJ software. Capsule and cell body dimensions were determined using Adobe Photoshop. Capsule radial length was calculated by subtracting the length of the cell body from the diameter of the whole cell, capsule included.

Gal-3 binding assay. The C. neoformans strains H99 (capsular) and CAP67 (acapsular) cells were incubated with PBS/10\% bovine fetal serum for $20 \mathrm{~min}$ at $4{ }^{\circ} \mathrm{C}$ to prevent nonspecific antibody binding. After washing, H99 and CAP67 cells at a density suspension of $1 \times 10^{6} \mathrm{cells} / \mathrm{ml}$ were incubated with native and denatured form of Gal-3 $(40 \mu \mathrm{g} / \mathrm{ml})$ for $40 \mathrm{~min}$ at $4{ }^{\circ} \mathrm{C}$. The cells were washed twice with PBS and the anti-Gal-3 antibody (1:50; Sigma-Aldrich) was added; after 45 min of incubation, the cells were washed with PBS and incubated with anti-rabbit IgGFITC antibody (1:50; Sigma-Aldrich) for $40 \mathrm{~min}$ at $4{ }^{\circ} \mathrm{C}$. Gal-3 binding to $\mathrm{H} 99$ and CAP67 cells was analyzed by flow cytometry (Guava easyCyte, Guava Technologies, Millipore, Hayward, CA, USA) and the histogram represents the percentage of positive cells recognized by Gal-3. The anti-rabbit IgG-FITC antibody associated or not with Gal-3 was used as control, and use of WGA lectin $(30 \mu \mathrm{g} / \mathrm{ml})$ as control of binding with capsule or cell wall.

Confocal microscopy. C. neoformans yeast cells (H99 strain) were cultured at $37^{\circ} \mathrm{C}$ for $24 \mathrm{~h}$. The cells were incubated with Gal $-3(40 \mu \mathrm{g} / \mathrm{ml})$ at $37^{\circ} \mathrm{C}$ for $1 \mathrm{~h}$, followed by washing with PBS and fixation with PBS-buffered 3.7\% formaldehyde at $25^{\circ} \mathrm{C}$ for $1 \mathrm{~h}$. After fixation, cells were washed with PBS and embedded in OCTTissue Tek (Electron Microscopy Sciences, Hatfield, PA, USA). The samples were frozen and processed as described previously ${ }^{49}$. Slides were rinsed three times with PBS before and after treatment with glycine $(0.1 \mathrm{M}, 15 \mathrm{~min})$, and blocked with BSA ( $1 \%$ in PBS) for $1 \mathrm{~h}$. Samples were incubated overnight at $4{ }^{\circ} \mathrm{C}$ with murine monoclonal antibody $18 \mathrm{~B} 7$ (IgG1, $1 \mu \mathrm{g} / \mathrm{ml}$ ), which binds cryptococcal glucuronoxylomannan (GXM) from all serotypes ${ }^{50}$. After washing with PBS, the cells were incubated with a rabbit anti-Gal-3 antibody (Sigma-Aldrich) overnight at $4^{\circ}$ C. The samples were washed five times with PBS and incubated for $1 \mathrm{~h}$ with or FITC-labeled secondary antibodies, which included Alexa Fluor 594-labeled goat anti-mouse IgG from Thermo Fisher Scientific and a FITC-labeled donkey antirabbit IgG from Jackson Immuno Research Laboratories. For cell wall detection, samples were incubated with Calcofluor White $(50 \mu \mathrm{g} / \mathrm{ml})$ (Sigma-Aldrich) in PBS for 20 min. After five washes with PBS (5 min each), coverslips were mounted with Fluoromount-G (Electron Microscopy Sciences). Samples were treated with preimmune serum from mice or rabbit and later treated with secondary antibodies as nonspecific labeling control. The samples were examined with a LSM780 system

Fig. 6 Gal-3 interacts with the C. neoformans capsule and inhibits the fungal growth. Capsular strain H99 (a and c) and acapsular strain CAP67 (b and d) were incubated for $72 \mathrm{~h}$ at $37^{\circ} \mathrm{C}$ with Gal-3 (0.001 to $10 \mu \mathrm{g} / \mathrm{ml}$ ), and the optical density at $540 \mathrm{~nm}$ (OD540) measured every hour (a and $\mathbf{b}$ ), or the number or colony-forming units (CFU) were counted for determination of cell densities (c and d). e H99 and CAP67 strains were incubated for $72 \mathrm{~h}$ at $37^{\circ}$ C with Gal-3 $(10 \mu \mathrm{g} / \mathrm{ml})$, and the frequency of viable cells assessed using propidium iodide staining. Heated fungal cells $\left(90^{\circ} \mathrm{C}\right.$ for $\left.10 \mathrm{~min}\right)$ were used as positive control (blue bar). $\mathrm{H} 99$ and CAP67 strains were incubated for $40 \mathrm{~min}$ at $4^{\circ} \mathrm{C}$ with $\mathrm{Gal}-340 \mu \mathrm{g} / \mathrm{ml}$. After that, both strains were washed with PBS and incubated for $45 \mathrm{~min}$ with anti-Gal-3 antibody. Then, washed again with PBS and incubated with anti-rabbit IgG-FITC antibody for 40 min at $4{ }^{\circ} \mathrm{C}$. Labeled cells were acquired on a FACS Guava easyCyte, and the histogram represents the percentage of positive cells recognized by Gal-3 (f). Anti-rabbit IgG-FITC antibody associated or not with Gal-3 was used as control, and use of WGA lectin $(30 \mu \mathrm{g} / \mathrm{ml})$ as control of binding with capsule or cell wall (f). $\mathbf{g}$ H99 strain was cultured at $37^{\circ} \mathrm{C}$ for $24 \mathrm{~h}$ and incubated with Gal-3. C. neoformans were stained for observation of cell wall (CW) with calcofluor white (blue), Gal-3 with anti-Gal-3 antibody (green), and capsule with anti-GXM (red). Body (h), and capsule (i) size of H99 strain cells were assessed by microscopic analysis after cultivation in the presence of Gal-3 $10 \mu \mathrm{g} / \mathrm{ml}$. Data are representative of three experiments. Statistically significant differences are denoted by asterisk $\left({ }^{*} p<0.05\right.$, unpaired Student's $t$-test) 
Table 1 List of top 40 induced genes with annotated functions upon exposure to Gal-3

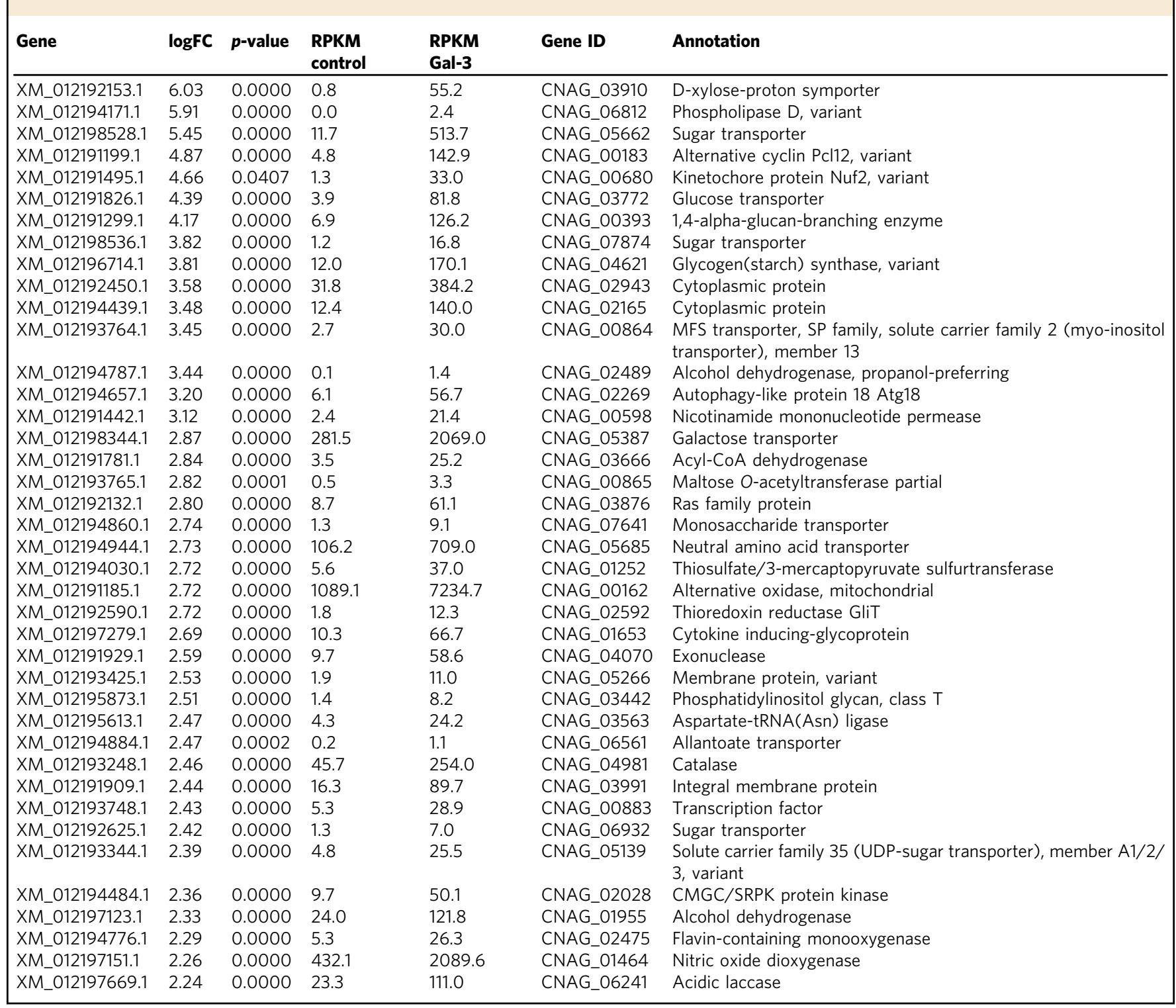

AxioObserver, $63 \mathrm{X}$ oil immersion (Carl Zeiss, Jena, Germany). The images were analyzed offline using the ImageJ software (http://rsb.info.nih.gov/ij/).

Cytokine measurements in tissues. The homogenates of lung, brain, and spleen were centrifuged at $2000 \times g$ for $15 \mathrm{~min}$ at $4{ }^{\circ} \mathrm{C}$. The supernatants were used to quantify the levels of IFN- $\gamma$, IL-12p40, IL-6, TNF- $\alpha$, and IL-10. The cytokines were measured by capture ELISA with antibody pairs purchased from BD Biosciences (Pharmingen, San Diego, CA, USA). The ELISA was performed according to the manufacturer's protocol. The cytokine concentrations were determined from standard curves, using murine recombinant cytokines as a standard. The absorbance was read at $450 \mathrm{~nm}$ in a microplate scanning spectrophotometer (Power Wave-X; BioTek Instruments, Inc., Winooski, VT, USA). The cytokine concentrations were determined in $\rho \mathrm{g} / \mathrm{ml}$ and related to organ mass, then expressed in $\mathrm{pg} / \mathrm{ml} / \mathrm{mg}$.

Quantitative reverse transcription (qRT)-PCR of transcription factors. Total RNA was obtained from lungs by TRIzol Reagent, according to the manufacturer's instructions. Reverse transcription of RNA into CDNA was done by the ImProm-II Reverse Transcription System (Promega, Fitchburg, WI, USA) using oligo (dT). The qRT-PCR was performed in $15 \mu$ l reactions with SsoFast ${ }^{\mathrm{TM}}$ EvaGreen (BioRad Laboratories, Hercules, CA, USA). The reactions were read in the Bio-Rad CFX96 Real-Time PCR System (Bio-Rad Laboratories) using the following conditions: $95^{\circ} \mathrm{C}$ for $30 \mathrm{~s}$, and 40 cycles of $95^{\circ} \mathrm{C}$ for $5 \mathrm{~s} / 60^{\circ} \mathrm{C}$ for $5 \mathrm{~s}$. Gene expression was quantified using the $\Delta \Delta \mathrm{Ct}$ method and normalized to $\beta$-actin expression. The utilized PCR primers were: $\beta$-actin (F: 5'-AGCTGCGTTTTACACCCTTT-3' / R: 5'-AAGCCATGCCAATGTTGTCT-3'); T-bet (F: CACTAAGCAAGGACGGCGAA / R: CCACCAAGACCACATCCAC); GATA-3 (F: AAGAAAGGCA TGAAGGACGC / R: GTGTGCCCA TTTGGACA TCA); ROR- $\gamma$ t (F: TGGAAGATGTGGACTTCGTT / R: TGGTTCCCCAAGTTCAGGAT).

Flow cytometric analysis of pulmonary leukocytes. Pulmonary leukocytes were isolated as described previously ${ }^{51}$ with slight modifications. WT and gal $3^{-/}$mice infected with C. neoformans (H99 strain) were killed on day 3 post-infection and their lungs removed aseptically. The lungs were fragmented and digested with type II collagenase $\left(1 \mathrm{mg} / \mathrm{ml}\right.$; Thermo Fisher Scientific) at $37^{\circ} \mathrm{C}$ for $30 \mathrm{~min}$. The cells were filtered on nylon filters $(70 \mu \mathrm{m}$; Thermo Fisher Scientific) and washed with sterile PBS. For erythrocyte elimination, cell suspensions were treated with $500 \mu \mathrm{l}$ of $\mathrm{NH}_{4} \mathrm{Cl}$ buffer for $5 \mathrm{~min}$ on ice followed by the addition of 10 -fold excess PBS. Leukocytes were centrifuged at $800 \times g$ for $5 \mathrm{~min}$, washed twice with sterile PBS and suspended in sterile PBS containing $2 \%$ heat-inactivated fetal bovine serum (FACS buffer). The cells were counted in a Neubauer's hematocytometer and adjusted to the density of $10^{7}$ cells $/ \mathrm{ml}$. Fifty microlitres of Fc block monoclonal antibody was added to each $100 \mu \mathrm{l}$ cell suspension, followed by incubation for $30 \mathrm{~min}$ on ice to inhibit non-specific binding. The cells were then incubated with a biotinylated hamster anti-mouse $\gamma \delta$ T-cell receptor antibody $(0.5 \mathrm{mg} / \mathrm{ml}$, BD Biosciences) for 1 $\mathrm{h}$ on ice. After washing with PBS, the cells were incubated with FITC-conjugated streptavidin $(10 \mu \mathrm{g} / \mathrm{ml}$, Thermo Fisher Scientific). The frequency of $\gamma \delta \mathrm{T}$ lymphocytes present in the pulmonary leukocytes was obtained by flow cytometry using a BD FACSCalibur (BD Biosciences) flow cytometer. 
Table 2 List of top $\mathbf{4 0}$ repressed genes with annotated functions upon exposure to Gal-3

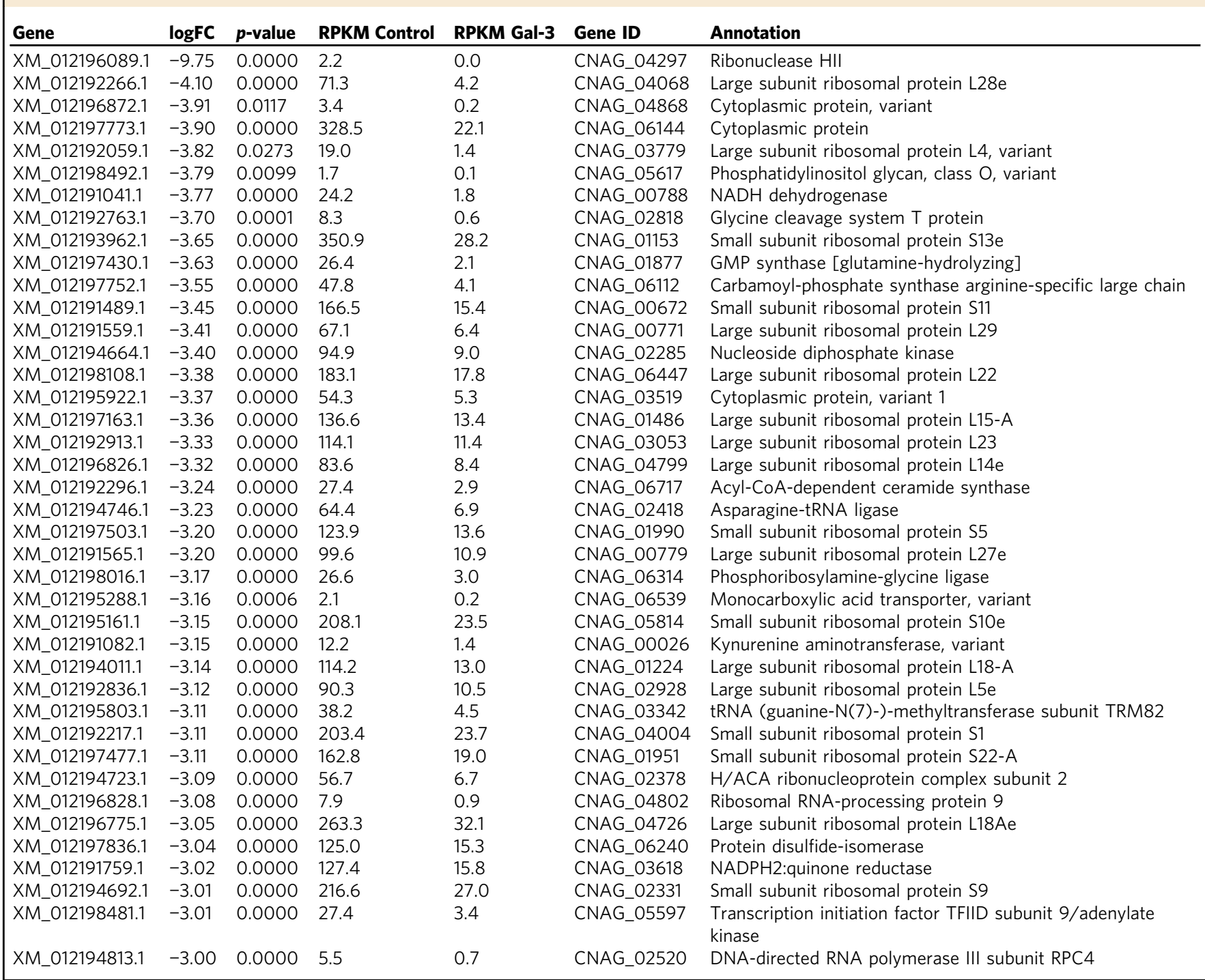

Analysis of the stability of extracellular vesicles. EVs were obtained as previously described ${ }^{52}$, with slight modifications. After fungal cells growth until the stationary phase $\left(1 \times 10^{7}\right.$ to $10^{8}$ cells $\left./ \mathrm{ml}\right)$, culture supernatants were separated by sequential centrifugation at $4000 \times g$ and $15,000 \times g$. Pellets were discarded, and the supernatants concentrated through Amicon ultrafiltration system with a $100-\mathrm{kDa}$ cutoff (Millipore, Billerica, MA, USA). The obtained material was ultracentrifuged at $100,000 \times g$ for $1 \mathrm{~h}$ at $4^{\circ} \mathrm{C}$. The supernatants were discarded, and the pellets were washed three times with PBS, by using successive steps of resuspension and centrifugation, at $100,000 \times g$ for $1 \mathrm{~h}$ at $4^{\circ} \mathrm{C}$. Vesicles detection was based on the sterol presence in their membranes by using a quantitative fluorimetric Amplex Red sterol assay kit (Molecular Probes, Thermo Fisher Scientific), according to the manufacturer's instructions. The EVs stability was evaluated according to protocols previously described ${ }^{16}$, with slight modifications. Briefly, EVs incubated at $37^{\circ} \mathrm{C}$, $5 \% \mathrm{CO}_{2}$, for $1 \mathrm{~h}$, with Gal-3 (\#G5170, Gal-3 human recombinant, expressed in E. coli, Sigma-Aldrich) at different final concentrations $(0-10 \mu \mathrm{g} / \mathrm{ml})$. The concentrations of all control lectins were normalized according to carbohydrate binding sites. Vesicle size was estimated by dynamic light scattering, for each experimental condition. Data were expressed as the average of three runs. EVs stability was also examined through a radioactive assay through cultivation of $C$. neoformans in the presence of $\left[1-{ }^{14} \mathrm{C}\right]$ palmitic acid ${ }^{16}$. The suspension of radiolabeled EVs was incubated with Gal-3 under the conditions described above and the suspension was ultracentrifuged at $100,000 \times g$ for $1 \mathrm{~h}$ at $4{ }^{\circ} \mathrm{C}$. Supernatants and pellets were saved for scintillation counting.

Vesicle disruption and uptake by macrophages. To study vesicle stability and vesicle uptake by macrophages from WT and gal $3^{-/-}$mice, we used a protocol that was previously described ${ }^{16}$, with slight modifications. Thioglycolate-elicited macrophages were harvested from the peritoneal cavity of C57BL/6 WT or gal3 ${ }^{-/}$ mice, and grown in DME medium (Invitrogen) supplemented with $10 \%(\mathrm{v} / \mathrm{v})$ fetal bovine serum, 10\% NCTC (Invitrogen), 1\% nonessential amino acids (Invitrogen) and $1 \%$ penicillin (Invitrogen). Forty-eight-well tissue culture plates were seeded with elicited peritoneal macrophages $\left(4 \times 10^{5}\right.$ cells/well). EVs were obtained from $C$ neoformans cultures that were pulsed with $\left[1-{ }^{14} \mathrm{C}\right]$ palmitic acid $72 \mathrm{~h}$ before EVs harvesting, as previously described ${ }^{16}$. A volume of $200 \mu \mathrm{l}$ of vesicle-containing medium was added to each well. Controls included vesicle-containing medium alone. After $1,2,6$, or $12 \mathrm{~h}$ incubation at $37^{\circ} \mathrm{C}$ in $9.5 \% \mathrm{CO}_{2}$, culture supernatants were collected. The adhered cells were also collected, washed three times with PBS, lysed in $200 \mu \mathrm{l}$ of $25 \mathrm{mM}$ deoxycholate and the resultant material was collected for scintillation counting. The harvested material from the culture supernatants was ultracentrifuged at $100,000 \times g$ for $1 \mathrm{~h}$ at $4{ }^{\circ} \mathrm{C}$. Supernatants (containing components of disrupted EVs) and pellets (containing intact EVs) were saved for scintillation counting. The radioactivity distribution in the three fractions was expressed as percent of the total radioactivity.

RNA sequencing and data analysis. Total RNA was obtained from three biological replicates of C. neoformans cells (H99 strain) incubated with minimal medium or Gal-3 $\left(0.1 \mu \mathrm{g} / \mathrm{ml}\right.$ in minimal medium) for $24 \mathrm{~h}$ at $37^{\circ} \mathrm{C}$. The cells were harvested by centrifugation, frozen in liquid nitrogen, and lysed with the use of mortar and pestle for total RNA isolation. Total RNA was obtained using Trizol (Invitrogen), treated with RNase-free DNA I (Fermentas), and cleaned up using an RNAeasy Kit (Qiagen Biotecnologia Brasil Ltda, Sao Paulo, SP, Brazil) following the manufacturer's instructions. The RNA was quantified using a Qubit 3.0 Fluorometer (Life Technologies), and analyzed using an Agilent 2100 Bioanalyzer system to assess the RNA integrity, which ranged from 9.5 to 9.9 (integrity 
a

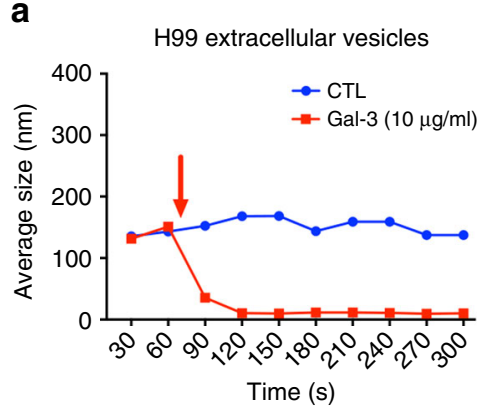

d

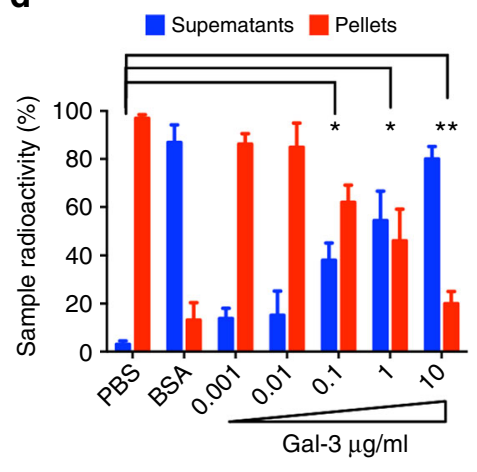

b

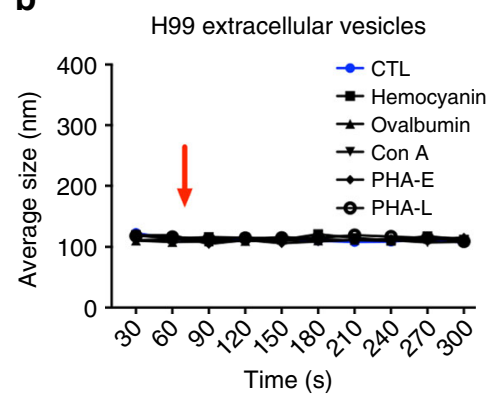

e

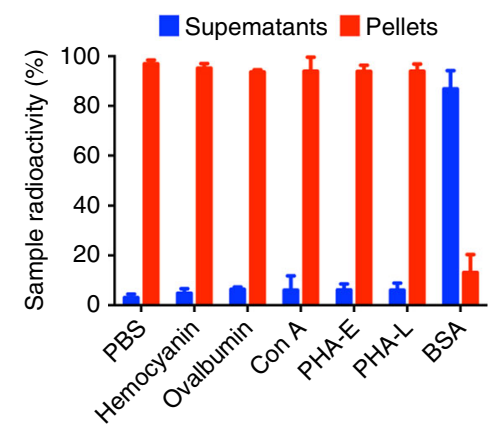

C

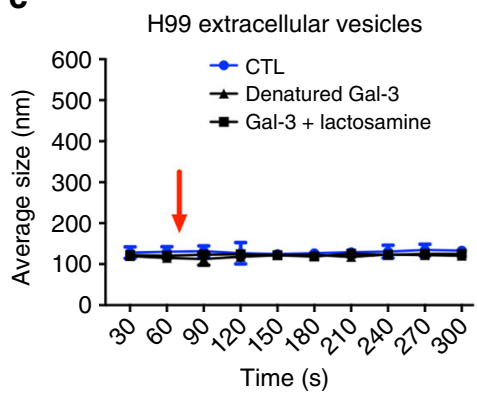

f

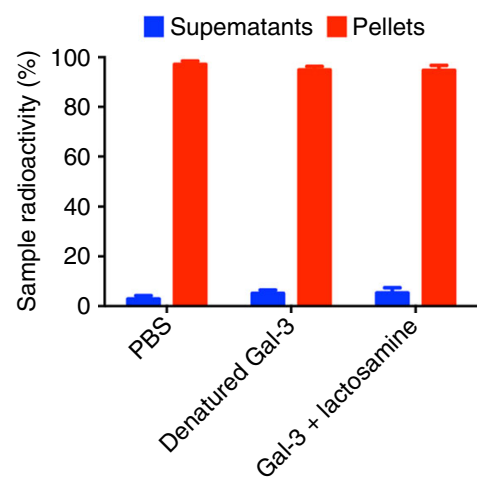

Fig. 7 Gal-3 disrupts C. neoformans extracellular vesicles. Temporal kinetics of vesicle disruption mediated by Gal-3 were measured by dynamic light scattering over ten $30 \mathrm{~s}$ to read the population average size (a-c). The addition of Gal-3 $10 \mu \mathrm{g}$ initially leads to disruption (a). The same samples were read first without (blue line) and then with the presence of Gal-3 (red line), which was added between the 60 and 90 s intervals (red arrow). Hemocyanin, ovalbumin, concanavalin A (Con A), phytohaemagglutinin E (PHA-E), and phytohaemagglutinin L (PHA-L) were used as control (b). Also denatured Gal-3 and Gal-3 pre-incubated with lactosamine were used as control (c). Purified radiolabeled vesicles after $72 \mathrm{~h}$ post $\left[1-{ }^{14} \mathrm{C}\right]$ palmitic acid addition were resuspended in PBS, BSA, Gal-3 (0.001 to $10 \mu \mathrm{g} / \mathrm{ml})(\mathbf{d})$, hemocyanin, ovalbumin, Con A, PHA-E, and PHA-L (e), denatured Gal-3 and Gal-3 pre-incubated with lactosamine (f), and supernatant (blue bars) and pellet (red bars) radioactivity were assessed and normalized to $100 \%$ radioactivity for each individual sample. Bars represent the mean \pm SD from triplicate samples. Statistically significant differences are denoted by asterisks $\left({ }^{\star} p<0.05,{ }^{\star \star} p<\right.$ 0.005, unpaired Student's $t$-test)

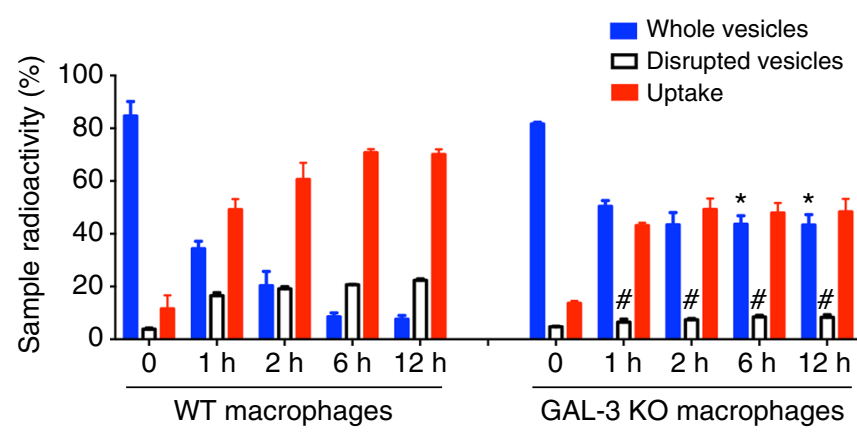

Fig. 8 Gal-3 is important for disruption and internalization of C. neoformans EVs by macrophages. Purified radiolabeled EVs were added to cultures of C57BL6 WT or Gal- $3^{-/-}$macrophages. After $1,2,6$, or $12 \mathrm{~h}$ post EVs addition, the radioactivity recovered from the macrophages (adhered cells, uptake, red bars), intact vesicles (pellet, blue bars), and disrupted vesicles (supernatant, white bars) were counted by scintillation

number). The barcoded libraries were prepared and sequenced in the Center for Medical Genomics of the Ribeirao Preto Medical School (Ribeirao Preto, Brazil) using the Illumina Truseq mRNA Sample Preparation kit according to the manufacturer's recommendations. Subsequent clustering and sequencing were performed with the Illumina NextSeq 500 system. Paired-end reads were demultiplexed and analyzed against C. neoformans reference genes using the Kallisto software (version 0.43 .1$)^{53}$, resulting in an average value of $21 \mathrm{M}$ reads per sample. Differentially expressed genes were analyzed using edge $^{54}$. Gene expression changes in the range of $>1.0$ or $<-1.0 \log$ fold $(p<0.05)$ were classified as biologically and statistically significant.

Statistical analysis. Data are either the means of or representative results from at least three independent experiments, each performed in triplicate. All statistical analyses and comparisons were performed using the GraphPad Prism Software version 6.0 (GraphPad Software, San Diego, CA, USA). The log rank test was used to compare the survival rates between the study groups. A $p$-value $<0.05$ was considered statistically significant.

Data availability. The RNA sequence data have been deposited in NCBI under BioProject accession number PRJNA415606. All other relevant data supporting the findings of the study are available in this article and its Supplementary Information files, or from the corresponding author upon request.

Received: 29 May 2017 Accepted: 8 November 2017

Published online: 06 December 2017

\section{References}

1. Heitman, J., Kozel, T. R., Kwon-Chung, J., Perfect, J. R. \& Casadevall, A. Cryptococcus: From Human Pathogen to Model Yeast. (ASM Press: Washington, DC, 2011).

2. Barnett, J. A. A history of research on yeasts 14 : medical yeasts part 2, Cryptococcus neoformans. Yeast (Chichester, Engl.) 27, 875-904 (2010).

3. Lin, X. \& Heitman, J. The biology of the Cryptococcus neoformans species complex. Annu. Rev. Microbiol. 60, 69-105 (2006). 
4. Lindell, D. M., Ballinger, M. N., McDonald, R. A., Toews, G. B. \& Huffnagle, G. B. Immunologic homeostasis during infection: coexistence of strong pulmonary cell-mediated immunity to secondary Cryptococcus neoformans infection while the primary infection still persists at low levels in the lungs. J. Immunol. 177, 4652-4661 (2006).

5. Coelho, C., Bocca, A. L. \& Casadevall, A. The intracellular life of Cryptococcus neoformans. Annu Rev. Pathol.-Mech. 9, 219-238 (2014).

6. Longo, D. et al. Harrison's Principles of Internal Medicine. 18th edn, 1, 2, (McGraw-Hill: New York, 2011).

7. Zaragoza, O. et al. The capsule of the fungal pathogen Cryptococcus neoformans. Adv. Appl. Microbiol. 68, 133-216 (2009).

8. Casadevall, A., Rosas, A. L. \& Nosanchuk, J. D. Melanin and virulence in Cryptococcus neoformans. Curr. Opin. Microbiol. 3, 354-358 (2000).

9. Casadevall, A., \& Perfect, J. R. Cryptococcus neoformans. (ASM Press: Washington, DC, 1998).

10. Almeida, F., Wolf, J. M. \& Casadevall, A. Virulence-associated enzymes of Cryptococcus neoformans. Eukaryot. Cell. https://doi.org/10.1128/EC.00103-15 (2015).

11. Brown, L., Wolf, J. M., Prados-Rosales, R. \& Casadevall, A. Through the wall: extracellular vesicles in Gram-positive bacteria, mycobacteria and fungi. Nat. Rev. Microbiol. 13, 620-630 (2015).

12. da Silva, T. A., Roque-Barreira, M. C., Casadevall, A. \& Almeida, F. Extracellular vesicles from Paracoccidioides brasiliensis induced M1 polarization in vitro. Sci. Rep. 6, 35867 (2016).

13. Oliveira, D. L. et al. Extracellular vesicles from Cryptococcus neoformans modulate macrophage functions. Infect. Immun. 78, 1601-1609 (2010).

14. Rodrigues, M. L. et al. Extracellular vesicles produced by Cryptococcus neoformans contain protein components associated with virulence. Eukaryot. Cell 7, 58-67 (2008).

15. Vargas, G. et al. Compositional and immunobiological analyses of extracellular vesicles released by Candida albicans. Cell. Microbiol. 17, 389-407 (2015).

16. Wolf, J. M., Rivera, J. \& Casadevall, A. Serum albumin disrupts Cryptococcus neoformans and Bacillus anthracis extracellular vesicles. Cell. Microbiol. 14, 762-773 (2012).

17. Fermino, M. L. et al. Galectin-3 negatively regulates the frequency and function of CD4(+)CD25(+)Foxp3(+) regulatory T cells and influences the course of Leishmania major infection. Eur. J. Immunol. 43, 1806-1817 (2013).

18. Ferraz, L. C. et al. Lack of galectin-3 alters the balance of innate immune cytokines and confers resistance to Rhodococcus equi infection. Eur. J. Immunol. 38, 2762-2775 (2008).

19. van den Berg, T. K. et al. LacdiNAc-glycans constitute a parasite pattern for galectin-3-mediated immune recognition. J. Immunol. 173, 1902-1907 (2004).

20. Baum, L. G., Garner, O. B., Schaefer, K. \& Lee, B. Microbe-host interactions are positively and negatively regulated by galectin-glycan interactions. Front. Immunol. 5, 284 (2014).

21. Breuilh, L. et al. Galectin-3 modulates immune and inflammatory responses during helminthic infection: impact of galectin-3 deficiency on the functions of dendritic cells. Infect. Immun. 75, 5148-5157 (2007).

22. Bernardes, E. S. et al. Toxoplasma gondii infection reveals a novel regulatory role for galectin-3 in the interface of innate and adaptive immunity. Am. J. Pathol. 168, 1910-1920 (2006).

23. Ruas, L. P. et al. Lack of galectin-3 drives response to Paracoccidioides brasiliensis toward a Th2-biased immunity. PLoS ONE 4, e4519 (2009).

24. Linden, J. R., De Paepe, M. E., Laforce-Nesbitt, S. S. \& Bliss, J. M. Galectin-3 plays an important role in protection against disseminated candidiasis. Med. Mycol. 51, 641-651 (2013).

25. Wu, S. Y., Yu, J. S., Liu, F. T., Miaw, S. C. \& Wu-Hsieh, B. A. Galectin-3 negatively regulates dendritic cell production of IL-23/IL-17-axis cytokines in infection by Histoplasma capsulatum. J. Immunol. 190, 3427-3437 (2013).

26. Chen, H. L., Liao, F., Lin, T. N. \& Liu, F. T. Galectins and neuroinflammation. Adv. Neurobiol. 9, 517-542 (2014).

27. Saegusa, J. et al. Galectin-3 is critical for the development of the allergic inflammatory response in a mouse model of atopic dermatitis. Am. J. Pathol. 174, 922-931 (2009).

28. Cherayil, B. J., Chaitovitz, S., Wong, C. \& Pillai, S. Molecular cloning of a human macrophage lectin specific for galactose. Proc. Natl. Acad. Sci. USA 87, 7324-7328 (1990).

29. Liu, F. T. et al. Expression and function of galectin-3, a beta-galactoside-binding lectin, in human monocytes and macrophages. Am. J. Pathol. 147, 1016-1028 (1995).

30. Sano, H. et al. Critical role of galectin-3 in phagocytosis by macrophages. J. Clin. Invest. 112, 389-397 (2003).

31. Vasta, G. R. Roles of galectins in infection. Nat. Rev. Microbiol. 7, 424-438 (2009).

32. Liu, F. T. \& Hsu, D. K. The role of galectin-3 in promotion of the inflammatory response. Drug News Perspect. 20, 455-460 (2007).

33. Krzeslak, A. \& Lipinska, A. Galectin-3 as a multifunctional protein. Cell Mol. Biol. Lett. 9, 305-328 (2004).
34. Fermin Lee, A. et al. Galectin-3 modulates Th17 responses by regulating dendritic cell cytokines. Am. J. Pathol. 183, 1209-1222 (2013).

35. Wozniak, K. L., Hardison, S. E., Kolls, J. K. \& Wormley, F. L. Role of IL-17A on resolution of pulmonary C. neoformans infection. PLoS ONE 6, e17204 (2011).

36. Wozniak, K. L., Kolls, J. K. \& Wormley, F. L. Jr. Depletion of neutrophils in a protective model of pulmonary cryptococcosis results in increased IL-17A production by gammadelta T cells. BMC Immunol. 13, 65 (2012).

37. Zhang, Y. et al. Robust Th1 and Th17 immunity supports pulmonary clearance but cannot prevent systemic dissemination of highly virulent Cryptococcus neoformans H99. Am. J. Pathol. 175, 2489-2500 (2009).

38. Murdock, B. J., Huffnagle, G. B., Olszewski, M. A. \& Osterholzer, J. J. Interleukin-17A enhances host defense against cryptococcal lung infection through effects mediated by leukocyte recruitment, activation, and gamma interferon production. Infect. Immun. 82, 937-948 (2014).

39. Jouault, T. et al. Specific recognition of Candida albicans by macrophages requires galectin-3 to discriminate Saccharomyces cerevisiae and needs association with TLR2 for signaling. J. Immunol. 177, 4679-4687 (2006).

40. Hernandez-Santos, N. \& Gaffen, S. L. Th17 cells in immunity to Candida albicans. Cell Host Microbe 11, 425-435 (2012).

41. Fradin, C., Poulain, D. \& Jouault, T. Beta-1,2-linked oligomannosides from Candida albicans bind to a 32-kilodalton macrophage membrane protein homologous to the mammalian lectin galectin-3. Infect. Immun. 68, 4391-4398 (2000).

42. Henrick, K., Bawumia, S., Barboni, E. A. M., Mehul, B. \& Hughes, R. C. Evidence for subsites in the galectins involved in sugar binding at the nonreducing end of the central galactose of oligosaccharide ligands: sequence analysis, homology modeling and mutagenesis studies of hamster galectin-3. Glycobiology 8, 45-57 (1998).

43. Kohatsu, L., Hsu, D. K., Jegalian, A. G., Liu, F. T. \& Baum, L. G. Galectin-3 induces death of Candida species expressing specific beta-1,2-linked mannans. J. Immunol. 177, 4718-4726 (2006).

44. Doering, T. L. How sweet it is! Cell wall biogenesis and polysaccharide capsule formation in Cryptococcus neoformans. Annu. Rev. Microbiol. 63, 223-247 (2009).

45. Guazzelli, L., McCabe, O. \& Oscarson, S. Synthesis of part structures of Cryptococcus neoformans serotype C capsular polysaccharide. Carbohyd. Res. 433, 5-13 (2016).

46. Ascenzi, P. \& Fasano, M. Serum heme-albumin: an allosteric protein. IUBMB Life 61, 1118-1122 (2009).

47. Meierhofer, T., van den Elsen, J. M., Cameron, P. J., Munoz-Berbel, X. \& Jenkins, A. T. The interaction of serum albumin with cholesterol containing lipid vesicles. J. Fluoresc. 20, 371-376 (2010).

48. Hsu, D. K. et al. Targeted disruption of the galectin-3 gene results in attenuated peritoneal inflammatory responses. Am. J. Pathol. 156, 1073-1083 (2000).

49. Oliveira, A. F. et al. Paracoccin distribution supports its role in Paracoccidioides brasiliensis growth and dimorphic transformation. PLoS ONE 12, e0184010 (2017).

50. Casadevall, A. et al. Characterization of a murine monoclonal antibody to Cryptococcus neoformans polysaccharide that is a candidate for human therapeutic studies. Antimicrob. Agents Chemother. 42, 1437-1446 (1998).

51. Chaturvedi, A. K. et al. Vaccine-mediated immune responses to experimental pulmonary Cryptococcus gattii infection in mice. PLoS ONE 9, e104316 (2014).

52. Rodrigues, M. L. et al. Vesicular polysaccharide export in Cryptococcus neoformans is a eukaryotic solution to the problem of fungal trans-cell wall transport. Eukaryot. Cell 6, 48-59 (2007).

53. Bray, N. L., Pimentel, H., Melsted, P. \& Pachter, L. Near-optimal probabilistic RNA-seq quantification. Nat. Biotechnol. 34, 525-527 (2016).

54. Robinson, M. D., McCarthy, D. J. \& Smyth, G. K. edgeR: a Bioconductor package for differential expression analysis of digital gene expression data. Bioinformatics 26, 139-140 (2010).

\section{Acknowledgements}

We would like to thank Johanna Rivera and Antonio Nakouzi from Albert Einsten College of Medicine, New York, USA, and Patricia Vendruscolo and Roberta Ribeiro Costa Rosales from Ribeirao Preto Medical School, Sao Paulo, Brazil, for technical support. We also thank Dr Kamila Peronni and Dr Wilson Araujo Silva Jr for RNA-seq data, and Dr Roberto Nascimento Silva for fruitful discussions and helping us to obtain RNA-seq analysis. M.L.R. acknowledges support from the Brazilian agencies Conselho Nacional de Desenvolvimento Científico e Tecnológico (CNPq), Fundação de Amparo à Pesquisa do Estado do Rio de Janeiro (FAPERJ) and from the Instituto Nacional de Ciência e Tecnologia de Inovação em Doenças de Populações Negligenciadas (INCTIDPN). F.A. received funding from Fundação de Amparo à Pesquisa do Estado de São Paulo (2016/03322-7, 2016/15055-3)—Project Young Researcher. A.C. was supported in part by NIH awards AI033142, AI052733, and HL059842. 


\section{Author contributions}

All of the authors contributed to the research design and data analyses. Performed the experiments: F.A., J.M.W., T.A.d.S., C.M.D.-R., C.P.R., A.M.P., F.F.F., R.S.-R. Contributed reagents/materials/analysis tools: F.A., R.M., M.L.R., M.C.R.-B., A.C. Wrote the paper: F.A., T.A.d.S., M.L.R., M.C.R.-B., A.C.

\section{Additional information}

Supplementary Information accompanies this paper at https://doi.org/10.1038/s41467017-02126-7.

Competing interests: The authors declare no competing financial interests.

Reprints and permission information is available online at http://npg.nature.com/ reprintsandpermissions/ (c) (i) Open Access This article is licensed under a Creative Commons Attribution 4.0 International License, which permits use, sharing, adaptation, distribution and reproduction in any medium or format, as long as you give appropriate credit to the original author(s) and the source, provide a link to the Creative Commons license, and indicate if changes were made. The images or other third party material in this article are included in the article's Creative Commons license, unless indicated otherwise in a credit line to the material. If material is not included in the article's Creative Commons license and your intended use is not permitted by statutory regulation or exceeds the permitted use, you will need to obtain permission directly from the copyright holder. To view a copy of this license, visit http://creativecommons.org/ licenses/by/4.0/.

(C) The Author(s) 2017 


\section{REFERÊNCIAS BIBLIOGRÁFICAS}

ALBRANDT, K.; ORIDA, N. K.; LIU, F. T. An IgE-binding protein with a distinctive repetitive sequence and homology with an IgG receptor. Proc Natl Acad Sci U S A, v. 84, n. 19, p. 6859-63, Oct 1987. ISSN 0027-8424. Disponível em: < https://www.ncbi.nlm.nih.gov/pubmed/2958848 >.

ALMEIDA, F. et al. Galectin-3 impacts Cryptococcus neoformans infection through direct antifungal effects. Nature Communications, v. 8, n. 1, p. 1968, 2017/12/06 2017. ISSN 20411723. Disponível em: < https://doi.org/10.1038/s41467-017-02126-7 >

ALMEIDA, F.; RODRIGUES, M. L.; COELHO, C. The Still Underestimated Problem of Fungal Diseases Worldwide. Frontiers in Microbiology, v. 10, p. 214, 2019. ISSN 1664302X. Disponível em: < https://www.frontiersin.org/article/10.3389/fmicb.2019.00214 >.

ANGKASEKWINAI, P. et al. Cryptococcus gattii infection dampens Th1 and Th17 responses by attenuating dendritic cell function and pulmonary chemokine expression in the immunocompetent hosts. Infect Immun, v. 82, n. 9, p. 3880-90, Sep 2014. ISSN 0019-9567.

ARORA, S. et al. Effect of cytokine interplay on macrophage polarization during chronic pulmonary infection with Cryptococcus neoformans. Infect Immun, v. 79, n. 5, p. 1915-26, May 2011. ISSN 0019-9567.

BAKER, R. D.; HAUGEN, R. K. Tissue changes and tissue diagnosis in cryptococcosis; a study of 26 cases. Am J Clin Pathol, v. 25, n. 1, p. 14-24, Jan 1955. ISSN 0002-9173. Disponível em: < https://www.ncbi.nlm.nih.gov/pubmed/14349908 >.

BARNETT, J. A. A history of research on yeasts 14: medical yeasts part 2, Cryptococcus neoformans. Yeast, v. 27, n. 11, p. 875-904, Nov 2010. ISSN 1097-0061. Disponível em: < https://www.ncbi.nlm.nih.gov/pubmed/20641025 >.

BARONDES, S. H. et al. Galectins: a family of animal beta-galactoside-binding lectins. Cell, v. 76, n. 4, p. 597-8, Feb 1994. ISSN 0092-8674. Disponível em: < https://www.ncbi.nlm.nih.gov/pubmed/8124704 >.

BAUMAN, S. K.; NICHOLS, K. L.; MURPHY, J. W. Dendritic cells in the induction of protective and nonprotective anticryptococcal cell-mediated immune responses. J Immunol, v. 165, n. 1, p. 158-67, Jul 1 2000. ISSN 0022-1767 (Print)0022-1767.

BIONDO, C. et al. MyD88 and TLR2, but not TLR4, are required for host defense against Cryptococcus neoformans. Eur J Immunol, v. 35, n. 3, p. 870-8, Mar 2005. ISSN 0014-2980 (Print)0014-2980.

BONGOMIN, F. et al. Global and Multi-National Prevalence of Fungal Diseases-Estimate Precision. J Fungi (Basel), v. 3, n. 4, Oct 18 2017. ISSN 2309-608x.

BORGES-WALMSLEY, M. I. et al. The pathobiology of Paracoccidioides brasiliensis. Trends Microbiol, v. 10, n. 2, p. 80-7, Feb 2002. ISSN 0966-842X (Print)0966-842x. 
BREWER, C. F.; MICELI, M. C.; BAUM, L. G. Clusters, bundles, arrays and lattices: novel mechanisms for lectin-saccharide-mediated cellular interactions. Curr Opin Struct Biol, v. 12, n. 5, p. 616-23, Oct 2002. ISSN 0959-440X. Disponível em: < https://www.ncbi.nlm.nih.gov/pubmed/12464313 >.

BRUBAKER, S. W. et al. Innate immune pattern recognition: a cell biological perspective. Annu Rev Immunol, v. 33, p. 257-90, 2015. ISSN 0732-0582.

CAMPUZANO, A.; WORMLEY, F. L. Innate Immunity against Cryptococcus, from Recognition to Elimination. J Fungi (Basel), v. 4, n. 1, Mar 2018. ISSN 2309-608X. Disponível em: < https://www.ncbi.nlm.nih.gov/pubmed/29518906 >.

CASADEVALL, A. et al. Characterization of a murine monoclonal antibody to Cryptococcus neoformans polysaccharide that is a candidate for human therapeutic studies. Antimicrob Agents Chemother, v. 42, n. 6, p. 1437-46, Jun 1998. ISSN 0066-4804. Disponível em: < https://www.ncbi.nlm.nih.gov/pubmed/9624491 >.

CHEN, M. et al. Internalized Cryptococcus neoformans Activates the Canonical Caspase-1 and the Noncanonical Caspase-8 Inflammasomes. J Immunol, v. 195, n. 10, p. 4962-72, Nov 15 2015. ISSN 0022-1767.

CHERNIAK, R.; SUNDSTROM, J. B. Polysaccharide antigens of the capsule of Cryptococcus neoformans. Infect Immun, v. 62, n. 5, p. 1507-12, May 1994. ISSN 0019-9567. Disponível em: 〈 https://www.ncbi.nlm.nih.gov/pubmed/8168912 >.

COOPER, D. N. Galectinomics: finding themes in complexity. Biochim Biophys Acta, v. 1572, n. 2-3, p. 209-31, Sep 2002. ISSN 0006-3002. Disponível em: < https://www.ncbi.nlm.nih.gov/pubmed/12223271 >.

CROSS, C. E.; BANCROFT, G. J. Ingestion of acapsular Cryptococcus neoformans occurs via mannose and beta-glucan receptors, resulting in cytokine production and increased phagocytosis of the encapsulated form. Infect Immun, v. 63, n. 7, p. 2604-11, Jul 1995. ISSN 0019-9567 (Print) 0019-9567.

DABELIC, S.; SUPRAHA, S.; DUMIC, J. Galectin-3 in macrophage-like cells exposed to immunomodulatory drugs. Biochim Biophys Acta, v. 1760, n. 4, p. 701-9, Apr 2006. ISSN 0006-3002. Disponível em: < https://www.ncbi.nlm.nih.gov/pubmed/16458432 >.

DAVIS, M. J. et al. Macrophage M1/M2 polarization dynamically adapts to changes in cytokine microenvironments in Cryptococcus neoformans infection. MBio, v. 4, n. 3, p. e00264-13, Jun 182013.

DENNIS, J. W. et al. Genetic defects in N-glycosylation and cellular diversity in mammals. Curr Opin Struct Biol, v. 11, n. 5, p. 601-7, Oct 2001. ISSN 0959-440X. Disponível em: < https://www.ncbi.nlm.nih.gov/pubmed/11785762 >.

DUMIC, J.; DABELIC, S.; FLÖGEL, M. Galectin-3: an open-ended story. Biochim Biophys Acta, v. 1760, n. 4, p. 616-35, Apr 2006. ISSN 0006-3002. Disponível em: < https://www.ncbi.nlm.nih.gov/pubmed/16478649 >. 
FRANCHI, L.; MUNOZ-PLANILLO, R.; NUNEZ, G. Sensing and reacting to microbes through the inflammasomes. Nat Immunol, v. 13, n. 4, p. 325-32, Mar 19 2012. ISSN 15292908.

FRED BREWER, C. Binding and cross-linking properties of galectins. Biochim Biophys Acta, v. 1572, n. 2-3, p. 255-62, Sep 2002. ISSN 0006-3002. Disponível em: < https://www.ncbi.nlm.nih.gov/pubmed/12223273 >.

GALLEGOS, B. et al. Lectins in human pathogenic fungi. Revista Iberoamericana de Micología, v. 31, n. 1, p. 72-75, 2014/01/01/ 2014. ISSN 1130-1406. Disponível em: < http://www.sciencedirect.com/science/article/pii/S1130140613001022 >.

GARCIA-HERMOSO, D.; JANBON, G.; DROMER, F. Epidemiological evidence for dormant Cryptococcus neoformans infection. J Clin Microbiol, v. 37, n. 10, p. 3204-9, Oct 1999. ISSN 0095-1137. Disponível em: < https://www.ncbi.nlm.nih.gov/pubmed/10488178 >.

GARRED, P. et al. A journey through the lectin pathway of complement-MBL and beyond. Immunological Reviews, v. 274, n. 1, p. 74-97, 2016/11/01 2016. ISSN 0105-2896. Disponível em: < https://doi.org/10.1111/imr.12468 >. Acesso em: 2019/03/10.

GAY, N. J. et al. Assembly and localization of Toll-like receptor signalling complexes. Nat Rev Immunol, v. 14, n. 8, p. 546-58, Aug 2014. ISSN 1474-1733.

GERSUK, G. M. et al. Dectin-1 and TLRs permit macrophages to distinguish between different Aspergillus fumigatus cellular states. J Immunol, v. 176, n. 6, p. 3717-24, Mar 15 2006. ISSN 0022-1767 (Print)0022-1767.

GILES, S. S. et al. Elucidating the pathogenesis of spores from the human fungal pathogen Cryptococcus neoformans. Infection and immunity, v. 77, n. 8, p. 3491-3500, 2009. ISSN 1098-55220019-9567. Disponível em: < https://www.ncbi.nlm.nih.gov/pubmed/19451235 >.Disponível em: < https://www.ncbi.nlm.nih.gov/pmc/PMC2715683/ >.

GOLDMAN, D. L. et al. Serologic evidence for Cryptococcus neoformans infection in early childhood. Pediatrics, v. 107, n. 5, p. E66, May 2001. ISSN 1098-4275. Disponível em: < https://www.ncbi.nlm.nih.gov/pubmed/11331716 >.

GOYAL, S.; KLASSERT, T. E.; SLEVOGT, H. C-type lectin receptors in tuberculosis: what we know. Medical microbiology and immunology, v. 205, n. 6, p. 513-535, 2016/12// 2016. ISSN 0300-8584. Disponível em: < http://europepmc.org/abstract/MED/27469378 >

GOYAL, S. et al. The Interaction of Human Pathogenic Fungi With C-Type Lectin Receptors. Frontiers in immunology, v. 9, p. 1261-1261, 2018. ISSN 1664-3224. Disponível em: < https://www.ncbi.nlm.nih.gov/pubmed/29915598 >.

GRAMBERG, T. et al. Evidence that multiple defects in murine DC-SIGN inhibit a functional interaction with pathogens. Virology, v. 345, n. 2, p. 482-491, 2006/02/20/ 2006. ISSN 00426822. Disponível em: < http://www.sciencedirect.com/science/article/pii/S0042682205006562 $>$. 
GUO, C. et al. Acapsular Cryptococcus neoformans activates the NLRP3 inflammasome. Microbes Infect, v. 16, n. 10, p. 845-54, Oct 2014. ISSN 1286-4579.

HARDISON, S. E. et al. Protective immunity against pulmonary cryptococcosis is associated with STAT1-mediated classical macrophage activation. J Immunol, v. 189, n. 8, p. 4060-8, Oct 15 2012. ISSN 0022-1767.

HERNÁNDEZ-SANTOS, N. et al. Th17 cells confer long-term adaptive immunity to oral mucosal Candida albicans infections. Mucosal Immunol, v. 6, n. 5, p. 900-10, Sep 2013. ISSN 1935-3456. Disponível em: < https://www.ncbi.nlm.nih.gov/pubmed/23250275 >.

HEUNG, L. J. Innate Immune Responses to Cryptococcus. Journal of fungi (Basel, Switzerland), v. 3, n. 3, p. 35, 2017. ISSN 2309-608X. Disponível em: < https://www.ncbi.nlm.nih.gov/pubmed/28936464 >.Disponível em: < https://www.ncbi.nlm.nih.gov/pmc/PMC5604851/ >.

HOLDER, G. E. et al. Expression of the mannose receptor CD206 in HIV and SIV encephalitis: a phenotypic switch of brain perivascular macrophages with virus infection. J Neuroimmune Pharmacol, v. 9, n. 5, p. 716-26, Dec 2014. ISSN 1557-1890.

HU, Y.; FARAH, C. S.; ASHMAN, R. B. Isolates of Candida albicans that differ in virulence for mice elicit strain-specific antibody-mediated protective responses. Microbes Infect, v. 8, n. 3, p. 612-20, Mar 2006. ISSN 1286-4579 (Print)1286-4579.

HUFFNAGLE, G. B. et al. Cutting Edge: Role of C-C Chemokine Receptor 5 in OrganSpecific and Innate Immunity to <em>Cryptococcus neoformans $</$ em>. The Journal of Immunology, v. 163, n. 9, p. 4642, 1999. Disponível em: < http://www.jimmunol.org/content/163/9/4642.abstract $>$.

HUNG, C. Y.; CASTRO-LOPEZ, N.; COLE, G. T. Card9- and MyD88-Mediated Gamma Interferon and Nitric Oxide Production Is Essential for Resistance to Subcutaneous Coccidioides posadasii Infection. Infect Immun, v. 84, n. 4, p. 1166-75, Apr 2016. ISSN 00199567.

ISHIKAWA, T. et al. Identification of distinct ligands for the C-type lectin receptors Mincle and Dectin-2 in the pathogenic fungus Malassezia. Cell Host Microbe, v. 13, n. 4, p. 477-88, Apr 17 2013. ISSN 1931-3128.

JOLLER, N.; WEBER, S. S.; OXENIUS, A. Antibody - Fc receptor interactions in protection against intracellular pathogens. European Journal of Immunology, v. 41, n. 4, p. 889-897, 2011/04/01 2011. ISSN 0014-2980. Disponível em: 〈 https://doi.org/10.1002/eji.201041340 >. Acesso em: 2019/03/12.

JOUAULT, T. et al. Specific recognition of Candida albicans by macrophages requires galectin-3 to discriminate Saccharomyces cerevisiae and needs association with TLR2 for signaling. J Immunol, v. 177, n. 7, p. 4679-87, Oct 2006. ISSN 0022-1767. Disponível em: < https://www.ncbi.nlm.nih.gov/pubmed/16982907 >. 
KASAI, K.; HIRABAYASHI, J. Galectins: a family of animal lectins that decipher glycocodes. J Biochem, v. 119, n. 1, p. 1-8, Jan 1996. ISSN 0021-924X. Disponível em: < https://www.ncbi.nlm.nih.gov/pubmed/8907168 >.

KASHEM, S. W. et al. Candida albicans morphology and dendritic cell subsets determine T helper cell differentiation. Immunity, v. 42, n. 2, p. 356-366, 2015. ISSN 1097-418010747613. Disponível em: < https://www.ncbi.nlm.nih.gov/pubmed/25680275 >.Disponível em: < https://www.ncbi.nlm.nih.gov/pmc/PMC4343045/ >.

KAWAI, T.; AKIRA, S. Toll-like receptors and their crosstalk with other innate receptors in infection and immunity. Immunity, v. 34, n. 5, p. 637-50, May 27 2011. ISSN 1074-7613.

KIM, Y. K.; SHIN, J. S.; NAHM, M. H. NOD-Like Receptors in Infection, Immunity, and Diseases. Yonsei Med J, v. 57, n. 1, p. 5-14, Jan 2016. ISSN 0513-5796.

KRONSTAD, J. et al. Adaptation of Cryptococcus neoformans to mammalian hosts: integrated regulation of metabolism and virulence. Eukaryot Cell, v. 11, n. 2, p. 109-18, Feb 2012. ISSN 1535-9786. Disponível em: < https://www.ncbi.nlm.nih.gov/pubmed/22140231 >.

LEIBUNDGUT-LANDMANN, S. et al. Syk- and CARD9-dependent coupling of innate immunity to the induction of $\mathrm{T}$ helper cells that produce interleukin 17. Nature Immunology, v. 8, p. 630, 04/22/online 2007. Disponível em: 〈 https://doi.org/10.1038/ni1460 >.

LEOPOLD WAGER, C. M. et al. Cryptococcus and Phagocytes: Complex Interactions that Influence Disease Outcome. Front Microbiol, v. 7, p. 105, 2016. ISSN 1664-302X (Print) 1664-302x.

LIN, X.; HEITMAN, J. The biology of the Cryptococcus neoformans species complex. Annu Rev Microbiol, v. 60, p. 69-105, 2006. ISSN 0066-4227. Disponível em: < https://www.ncbi.nlm.nih.gov/pubmed/16704346 >.

LINDELL, D. M. et al. Immunologic homeostasis during infection: coexistence of strong pulmonary cell-mediated immunity to secondary Cryptococcus neoformans infection while the primary infection still persists at low levels in the lungs. J Immunol, v. 177, n. 7, p. 4652-61, Oct 2006. ISSN 0022-1767. Disponível em: < https://www.ncbi.nlm.nih.gov/pubmed/16982904 >.

LINDEN, J. R. et al. Galectin-3 plays an important role in protection against disseminated candidiasis. Med Mycol, v. 51, n. 6, p. 641-51, Aug 2013. ISSN 1460-2709. Disponível em: < https://www.ncbi.nlm.nih.gov/pubmed/23488971 >.

LIU, F. T.; RABINOVICH, G. A. Galectins as modulators of tumour progression. Nat Rev Cancer, v. 5, n. 1, p. 29-41, Jan 2005. ISSN 1474-175X. Disponível em: < https://www.ncbi.nlm.nih.gov/pubmed/15630413 >.

LOHMANN-MATTHES, M. L.; STEINMULLER, C.; FRANKE-ULLMANN, G. Pulmonary macrophages. European Respiratory Journal, v. 7, n. 9, p. 1678, 1994. Disponível em: < http://erj.ersjournals.com/content/7/9/1678.abstract $>$. 
LONGO D et al. Harrison's Principles of Internal Medicine. In: (Ed.). 18. McGraw-Hill. , New York. , v.vol 1,2., 2011.

LOURES, F. V. et al. MyD88 signaling is required for efficient innate and adaptive immune responses to Paracoccidioides brasiliensis infection. Infect Immun, v. 79, n. 6, p. 2470-80, Jun 2011. ISSN 0019-9567.

LOURES, F. V. et al. TLR-4 cooperates with Dectin-1 and mannose receptor to expand Th17 and Tc17 cells induced by Paracoccidioides brasiliensis stimulated dendritic cells. Frontiers in microbiology, v. 6, p. 261-261, 2015. ISSN 1664-302X. Disponível em: < https://www.ncbi.nlm.nih.gov/pubmed/25873917 >.

MA, H.; MAY, R. C. Virulence in Cryptococcus species. Adv Appl Microbiol, v. 67, p. 13190, 2009. ISSN 0065-2164. Disponível em: < https://www.ncbi.nlm.nih.gov/pubmed/19245939 >.

MA, Y. J. et al. Ficolin-1-PTX3 complex formation promotes clearance of altered self-cells and modulates IL-8 production. J Immunol, v. 191, n. 3, p. 1324-33, Aug 1 2013. ISSN 00221767.

MANSOUR, M. K.; LATZ, E.; LEVITZ, S. M. Cryptococcus neoformans Glycoantigens Are Captured by Multiple Lectin Receptors and Presented by Dendritic Cells. The Journal of Immunology, v. 176, n. 5, p. 3053, 2006. Disponível em: < http://www.jimmunol.org/content/176/5/3053.abstract $>$.

MAYER, S.; RAULF, M.-K.; LEPENIES, B. C-type lectins: their network and roles in pathogen recognition and immunity. Histochemistry and Cell Biology, v. 147, n. 2, p. 223237, 2017/02/01 2017. ISSN 1432-119X. Disponível em: < https://doi.org/10.1007/s00418$\underline{016-1523-7}>$.

MCQUISTON, T. J.; WILLIAMSON, P. R. Paradoxical roles of alveolar macrophages in the host response to Cryptococcus neoformans. J Infect Chemother, v. 18, n. 1, p. 1-9, Feb 2012. ISSN 1341-321x.

MUKHERJEE, S.; LEE, S. C.; CASADEVALL, A. Antibodies to Cryptococcus neoformans glucuronoxylomannan enhance antifungal activity of murine macrophages. Infect Immun, v. 63, n. 2, p. 573-9, Feb 1995. ISSN 0019-9567 (Print) 0019-9567.

MURRAY, P. J.; WYNN, T. A. Protective and pathogenic functions of macrophage subsets. Nat Rev Immunol, v. 11, n. 11, p. 723-37, Oct 14 2011. ISSN 1474-1733.

NAKAMURA, K. et al. Dectin-1 Is Not Required for the Host Defense to Cryptococcus neoformans. Microbiology and Immunology, v. 51, n. 11, p. 1115-1119, 2007/11/01 2007. ISSN 0385-5600. Disponível em: < https://doi.org/10.1111/j.1348-0421.2007.tb04007.x >. Acesso em: 2019/03/06.

NAKAMURA, Y. et al. Dectin-2 deficiency promotes Th2 response and mucin production in the lungs after pulmonary infection with Cryptococcus neoformans. Infect Immun, v. 83, n. 2, p. 671-81, Feb 2015. ISSN 0019-9567. 
NETEA, M. G. et al. Recognition of fungal pathogens by toll-like receptors. Curr Pharm Des, v. 12, n. 32, p. 4195-201, 2006. ISSN 1381-6128.

OSCARSON, S. et al. Synthesis and immunological studies of glycoconjugates of Cryptococcus neoformans capsular glucuronoxylomannan oligosaccharide structures. Vaccine, v. 23, n. 30, p. 3961-72, Jun 2005. ISSN 0264-410X. Disponível em: < https://www.ncbi.nlm.nih.gov/pubmed/15917118 >.

OSTROP, J.; LANG, R. Contact, Collaboration, and Conflict: Signal Integration of SykCoupled C-Type Lectin Receptors. J Immunol, v. 198, n. 4, p. 1403-1414, Feb 15 2017. ISSN 0022-1767.

PELKA, K.; DE NARDO, D. Emerging Concepts in Innate Immunity. Methods Mol Biol, v. 1714, p. 1-18, 2018. ISSN 1064-3745.

PERFECT, J. R.; CASADEVALL, A. Cryptococcosis. Infect Dis Clin North Am, v. 16, n. 4, p. 837-74, v-vi, Dec 2002. ISSN 0891-5520. Disponível em: < https://www.ncbi.nlm.nih.gov/pubmed/12512184 >.

PLATO, A.; HARDISON, S. E.; BROWN, G. D. Pattern recognition receptors in antifungal immunity. Semin Immunopathol, v. 37, n. 2, p. 97-106, Mar 2015. ISSN 1863-2297.

RABINOVICH, G. A. et al. Galectins and their ligands: amplifiers, silencers or tuners of the inflammatory response? Trends Immunol, v. 23, n. 6, p. 313-20, Jun 2002. ISSN 1471-4906 (Print)1471-4906.

RAJASINGHAM, R. et al. Global burden of disease of HIV-associated cryptococcal meningitis: an updated analysis. The Lancet. Infectious diseases, v. 17, n. 8, p. 873-881, 2017. ISSN 1474-4457

1473-3099. Disponível em: < https://www.ncbi.nlm.nih.gov/pubmed/28483415 >.Disponível em: < https://www.ncbi.nlm.nih.gov/pmc/PMC5818156/ >.

RAMIREZ-ORTIZ, Z. G. et al. Toll-Like Receptor 9-Dependent Immune Activation by Unmethylated $\mathrm{CpG}$ Motifs in <em $>$ Aspergillus fumigatus $</ \mathrm{em}>\mathrm{DNA}$. Infection and Immunity, v. 76, n. 5, p. 2123, 2008. Disponível em: < http://iai.asm.org/content/76/5/2123.abstract $>$.

ROBERTSON, M. W. et al. Human IgE-binding protein: a soluble lectin exhibiting a highly conserved interspecies sequence and differential recognition of IgE glycoforms. Biochemistry, v. 29, n. 35, p. 8093-100, Sep 1990. ISSN 0006-2960. Disponível em: < https://www.ncbi.nlm.nih.gov/pubmed/2261464 >.

ROMANI, L. Immunity to fungal infections. Nat Rev Immunol, v. 11, n. 4, p. 275-88, Apr 2011. ISSN 1474-1741. Disponível em: < https://www.ncbi.nlm.nih.gov/pubmed/21394104 >.

RUAS, L. P. et al. Lack of Galectin-3 Drives Response to Paracoccidioides brasiliensis toward a Th2-Biased Immunity. PLOS ONE, v. 4, n. 2, p. e4519, 2009. Disponível em: < https://doi.org/10.1371/journal.pone.0004519 >. 
SHARON, N.; LIS, H. Lectins as cell recognition molecules. Science, v. 246, n. 4927, p. 227, 1989. Disponível em: < http://science.sciencemag.org/content/246/4927/227.abstract >.

SCHWARTZ, D. A. Characterization of the biological activity of Cryptococcus infections in surgical pathology. The Budding Index and Carminophilic Index. Ann Clin Lab Sci, v. 18, n. 5, p. 388-97, 1988 Sep-Oct 1988. ISSN 0091-7370. Disponível em: < https://www.ncbi.nlm.nih.gov/pubmed/2460017 >.

SHIMURA, T. et al. Galectin-3, a novel binding partner of beta-catenin. Cancer Res, v. 64, n. 18, p. 6363-7, Sep 2004. ISSN 0008-5472. Disponível em: < https://www.ncbi.nlm.nih.gov/pubmed/15374939 >.

SHIOKAWA, M.; YAMASAKI, S.; SAIJO, S. C-type lectin receptors in anti-fungal immunity. Curr Opin Microbiol, v. 40, p. 123-130, Dec 2017. ISSN 1369-5274.

SHOURIAN, M.; QURESHI, S. T. Resistance and Tolerance to Cryptococcal Infection: An Intricate Balance That Controls the Development of Disease. Front Immunol, v. 10, p. 66, 2019. ISSN 1664-3224.

SORGI, C. A. et al. Histoplasma capsulatum cell wall \{beta $\}$-glucan induces lipid body formation through CD18, TLR2, and dectin-1 receptors: correlation with leukotriene B4 generation and role in HIV-1 infection. J Immunol, v. 182, n. 7, p. 4025-35, Apr 1 2009. ISSN 0022-1767.

SOUTO, J. T. et al. Chemokine production and leukocyte recruitment to the lungs of Paracoccidioides brasiliensis-infected mice is modulated by interferon-gamma. The American journal of pathology, v. 163, n. 2, p. 583-590, 2003. ISSN 0002-94401525-2191. Disponível em: < https://www.ncbi.nlm.nih.gov/pubmed/12875978

STEELE, C. et al. Alveolar macrophage-mediated killing of Pneumocystis carinii f. sp. muris involves molecular recognition by the Dectin-1 beta-glucan receptor. J Exp Med, v. 198, n. 11, p. 1677-88, Dec 1 2003. ISSN 0022-1007 (Print)0022-1007.

Stop neglecting fungi. Nature Microbiology, v. 2, p. 17120, 07/25/online 2017. Disponível em: < https://doi.org/10.1038/nmicrobiol.2017.120 $>$.

TAKAHARA, K. et al. Efficient capture of Candida albicans and zymosan by SIGNR1 augments TLR2-dependent TNF-alpha production. Int Immunol, v. 24, n. 2, p. 89-96, Feb 2012. ISSN 0953-8178.

TARTEY, S.; TAKEUCHI, O. Pathogen recognition and Toll-like receptor targeted therapeutics in innate immune cells. Int Rev Immunol, v. 36, n. 2, p. 57-73, Mar 4 2017. ISSN 0883-0185.

TAKAHARA, K. et al. C-type lectin SIGNR1 enhances cellular oxidative burst response against C. albicans in cooperation with Dectin-1. Eur J Immunol, v. 41, n. 5, p. 1435-44, May 2011. ISSN 0014-2980. 
TAYLOR, P. R. et al. Dectin-1 is required for beta-glucan recognition and control of fungal infection. Nature immunology, v. 8, n. 1, p. 31-38, 2007. ISSN 1529-29081529-2916. Disponível em: < https://www.ncbi.nlm.nih.gov/pubmed/17159984

TRAYNOR, T. R.; HUFFNAGLE, G. B. Role of chemokines in fungal infections. Medical Mycology, v. 39, n. 1, p. 41-50, 2001/01/01 2001. ISSN 1369-3786. Disponível em: < https://www.tandfonline.com/doi/abs/10.1080/mmy.39.1.41.50 >.

TURNER, M. W. The role of mannose-binding lectin in health and disease. Molecular Immunology, v. 40, n. 7, p. 423-429, 2003/11/01/ 2003. ISSN 0161-5890. Disponível em: < http://www.sciencedirect.com/science/article/pii/S016158900300155X >.

VAN DE VEERDONK, F. L. et al. The macrophage mannose receptor induces IL-17 in response to Candida albicans. Cell Host Microbe, v. 5, n. 4, p. 329-40, Apr 23 2009. ISSN 1931-3128.

VASTA, G. R. et al. C-type lectins and galectins mediate innate and adaptive immune functions: their roles in the complement activation pathway. Developmental \& Comparative Immunology, v. 23, n. 4, p. 401-420, 1999/06/01/ 1999. ISSN 0145-305X. Disponível em: < http://www.sciencedirect.com/science/article/pii/S0145305X99000208 >.

VAUTIER, S.; MACCALLUM, D. M.; BROWN, G. D. C-type lectin receptors and cytokines in fungal immunity. Cytokine, v. 58, n. 1, p. 89-99, 2012/04/01/ 2012. ISSN 1043-4666. Disponível em: < http://www.sciencedirect.com/science/article/pii/S1043466611007101 >.

VECCHIARELLI, A. Immunoregulation by capsular components of Cryptococcus neoformans. Med Mycol, v. 38, n. 6, p. 407-17, Dec 2000. ISSN 1369-3786. Disponível em: < https://www.ncbi.nlm.nih.gov/pubmed/11204878 >.

VECCHIARELLI, A. et al. Elucidating the immunological function of the Cryptococcus neoformans capsule. Future Microbiol, v. 8, n. 9, p. 1107-16, Sep 2013. ISSN 1746-0913.

VIEIRA, P. L. et al. Development of Th1-inducing capacity in myeloid dendritic cells requires environmental instruction. J Immunol, v. 164, n. 9, p. 4507-12, May 1 2000. ISSN 0022-1767 (Print)0022-1767.

VIRIYAKOSOL, S. et al. Innate immunity to the pathogenic fungus Coccidioides posadasii is dependent on Toll-like receptor 2 and Dectin-1. Infect Immun, v. 73, n. 3, p. 1553-60, Mar 2005. ISSN 0019-9567 (Print)0019-9567.

WALSH, N. M. et al. Characterization of C-type lectins reveals an unexpectedly limited interaction between Cryptococcus neoformans spores and Dectin-1. PloS one, v. 12, n. 3, p. e0173866-e0173866, 2017. ISSN 1932-6203. Disponível em: < https://www.ncbi.nlm.nih.gov/pubmed/28282442 >

WANG, Q. et al. Role of the Mannose Receptor During Aspergillus fumigatus Infection and Interaction With Dectin-1 in Corneal Epithelial Cells. Cornea, v. 35, n. 2, p. 267-73, Feb 2016. ISSN 0277-3740. 
WOZNIAK, K. L.; LEVITZ, S. M. Cryptococcus neoformans enters the endolysosomal pathway of dendritic cells and is killed by lysosomal components. Infect Immun, v. 76, n. 10, p. 4764-71, Oct 2008. ISSN 0019-9567.

WOZNIAK, K. L.; VYAS, J. M.; LEVITZ, S. M. In vivo role of dendritic cells in a murine model of pulmonary cryptococcosis. Infect Immun, v. 74, n. 7, p. 3817-24, Jul 2006. ISSN 0019-9567 (Print)0019-9567.

WOZNIAK, K. L. et al. Role of IL-17A on Resolution of Pulmonary C. neoformans Infection. PLOS ONE, v. 6, n. 2, p. e17204, 2011. Disponível em: <https://doi.org/10.1371/journal.pone.0017204 >.

WOZNIAK, L. K. Interactions of Cryptococcus with Dendritic Cells. Journal of Fungi, v. 4, n. 1, 2018. ISSN 2309-608X.

WU, S. Y. et al. Galectin-3 negatively regulates dendritic cell production of IL-23/IL-17-axis cytokines in infection by Histoplasma capsulatum. J Immunol, v. 190, n. 7, p. 3427-37, Apr 2013. ISSN 1550-6606. Disponível em: < https://www.ncbi.nlm.nih.gov/pubmed/23455499 >.

XAPLANTERI, P. et al. Synergistic regulation of Pseudomonas aeruginosa-induced cytokine production in human monocytes by mannose receptor and TLR2. European Journal of Immunology, v. 39, n. 3, p. 730-740, 2009/03/01 2009. ISSN 0014-2980. Disponível em: < https://doi.org/10.1002/eji.200838872 >. Acesso em: 2019/03/10.

YANG, R. Y.; RABINOVICH, G. A.; LIU, F. T. Galectins: structure, function and therapeutic potential. Expert Rev Mol Med, v. 10, p. e17, Jun 2008. ISSN 1462-3994. Disponível em: < https://www.ncbi.nlm.nih.gov/pubmed/18549522 >.

YAUCH, L. E.; MANSOUR, M. K.; LEVITZ, S. M. Receptor-mediated clearance of Cryptococcus neoformans capsular polysaccharide in vivo. Infection and immunity, v. 73, n. 12, p. 8429-8432, 2005. ISSN 0019-95671098-5522. Disponível em: < https://www.ncbi.nlm.nih.gov/pubmed/16299344 >.

YUAN, R. et al. Antibody-mediated modulation of Cryptococcus neoformans infection is dependent on distinct Fc receptor functions and IgG subclasses. J Exp Med, v. 187, n. 4, p. 641-8, Feb 16 1998. ISSN 0022-1007 (Print)0022-1007. 